\title{
The Waterway of Hellespont and Bosporus: the Origin of the Names
}

\author{
and Early Greek Haplology
}

Dedicated to Henry and Renée Kahane*

\section{DEMETRIUS J. GEORGACAS}

\section{ABBREVIATIONS AND BIBLIOGRAPHY}

\section{A few abbreviations are listed:}

$A J A=$ American Journal of Archaeology .

$A J P=$ American Journal of Philology (The Johns Hopkins Press, Baltimore, Md.).

$B B=$ Bezzenbergers Beiträge zur Kunde der indogermanischen Sprachen.

$B N F=$ Beiträge zur Namenforschung (Heidelberg).

$C G L=$ Corpus Glossariorum Latinorum, ed. G. Goetz. 7 vols. Lipsiae, 1888-1903.

Chantraine, Dict. étym. = P. Chantraine, Dictionnaire étymologique de la langue grecque.

Histoire des mots. 2 vols: A-K. Paris, 1968, 1970.

Eberts $R L V=$ M. Ebert (ed.), Reallexikon der Vorgeschichte. 16 vols. Berlin, 1924-32.

$E B r=$ Encyclopaedia Britannica. 30 vols. Chicago, 1970.

$E E B \Sigma={ }^{\prime} E \pi \varepsilon \tau \eta \varrho i{ }^{~} E \tau \alpha \iota \varrho \varepsilon i a \varsigma ~ B v \zeta a v \tau \imath \tilde{\omega} v$ $\Sigma \pi o v \delta \tilde{\omega} \nu$ (Athens).



$E I s l=$ The Encyclopaedia of Islam (Leiden and London) 1 (1960) -.

Frisk, $G E W=\mathrm{H}$. Frisk, Griechisches etymologisches Wörterbuch. 2 vols. Heidelberg, 1954

to 1970.

GEL = Liddell-Scott-Jones, A Greek-English Lexicon. Oxford, 1925-40.

A Supplement, 1968.

GGM = Geographi Graeci Minores, ed. C. Müller.

$G L M=$ Geographi Latini Minores, ed. A. Riese.

$G R=$ Geographical Review (New York).

$G Z=$ Geographische Zeitschrift (Berlin).

$I F=$ Indogermanische Forschungen (Berlin).

$I G=$ Inscriptiones Graecae (Berlin).

$L B=$ Linguistique Balkanique (Sofia).

* A summary of this paper was read at the meeting of the Linguistic Circle of Manitoba and North Dakota on 24 October 1970. My thanks go to Prof. Edmund Berry of the Univ. of Manitoba for reading a draft of the present study and for stylistic and other suggestions, and to the Editor of Names, Dr. Conrad M. Rothrauff, for his remarks upon reading the same; I am also indebted for help to Prof. Edward Bassett, Univ. of Chicago, and Dr. Evangelos Petrounias, Univ. of Calif. at Los Angeles, and for useful pertinent information to Prof. P. Kannowski, Univ. of North Dakota; to Prof. G. G. Arnakis, Univ. of Texas, to Dr. Vasileios Christides, Univ. of Minnesota, to Prof. Dr. Gerhard Rohlfs, Tübingen; and Mr. Nikos Zervis, Kalamata (Greece). 
$O C D^{2}(1970)=$ Oxford Classical Dictionary. 2nd ed. Oxford: Clarendon Press, 1970. XXII, $1176 \mathrm{p}$.

$O C T=$ Oxford Classical Texts.

Pape-Benseler = W. Pape - G. E. Benseler, Wörterbuch der griechischen Eigennamen ${ }^{3}$. Braunschweig, 1870, 1911; Graz, 1958.

Pokorny, $I E W=$ J. Pokorny, Indogermanisches etymologisches Wörterbuch. 2 vols. Bern und München, 1959-69.

Proceed. of ICOS = Proceedings of the International Congress of Onomastic Sciences.

$R E=$ Pauly-Wissowa, Realencyclopädie der classischen Altertumswissenschaft.

$R E G=$ Revue des études grecques (Paris).

RhM = Rheinisches Museum für Philologie (Frankfurt a.M.).

$R L V=$ Reallexikon der Vorgeschichte. Berlin, 1924-32.

Roscher, Lexikon d. Mythol. $=$ W. H. Roscher, Ausführliches Lexikon der griechischen und römischen Mythologie. 6 vols. in 9. Leipzig, Berlin, 1884-1937. - See next section on details.

$S B=$ Sitzungsberichte.

$S I F C=$ Studi italiani di filologia classica (Firenze).

ThGL = Thesaurus Graecae Linguae (Paris).

$T h L L=$ Thesaurus Linguae Latinae (Munich).

\section{Bibliography}

Atlas of the World. Mid-Century Edition. Ed. by John Bartholomew. Vol. II: Southwest Asia \& Russia. London, Times Publishing Co., 1959. [Plate 37: Turkey East.]

Otfrid Becker, "Das Bild des Weges und verwandte Vorstellungen im frühgriechischen Denken," Hermes Einzelschriften, H. 4 (Berlin, 1937). 223 pp. [The third chapter





Serge von Bubnoff, Geologie von Europa (Berlin, 1939), 2, 3, pp. $1472 \mathrm{f}$.

—, Neue Jahrbücher für Mineralogie, Geologie und Paläontologie 3 (1938), 1068.

L. Bürchner, art. Hellespontos, RE 8 (1912), 182-188.

Viktor Burr, Nostrum Mare; Ursprung und Geschichte der Namen des Mittelmeeres und seiner Teilmeere im Altertum. Stuttgart, 1932 (Würzburger Studien zur Altertumswissenschaft, 4. Heft). [On the Hellespont, the Propontis and the Bosporos, Thracian and Cimmerian, including the names, pp. 11-37. This item and Ronconi's (below) are indispensable.]

A. Ch. Chatzis, "“E $\mathrm{E} \lambda \lambda \eta-{ }^{-} \mathrm{E} \lambda \lambda \alpha \alpha_{\varsigma}-{ }^{\prime \prime} \mathrm{E} \lambda \lambda \eta \nu,{ }^{\prime} \mathrm{EE} \Phi \Sigma$ of the University of Athens 1 (1935,


p. 136 with notes 2 and 3 ; on "E $\mathrm{A} \lambda \eta$, p. 135 f., 137 with notes $1-3,138$. The author is unaware of previous important bibliography such as Burr, Ronconi, Becker, etc.]

Ch. M. Danoff, art. Pontos Euxeinos, RE, N.B., Suppl.-Band 9 (1962), 866-1175. [§11, 950-955: Die Namen des Pontos Euxeinos und seiner Teile.]

Dimiter Detschew, Die thrakischen Sprachreste. Wien, 1957. (Österreich. Akad. d. Wiss., philos.-hist. Kl.; Schriften der Balkankommission, Lingu. Abt. XIV). [On the place-


33 (1957), 439-40; A. Heubeck, BNF 9 (1958) 118-122; G. Solta, IF 46 (1961) 65-78.]

-, Charakteristik der thrakischen Sprache. Sofia, 1952. (Public. de l'Acad. Bulgare des Sciences.) A new ed., $L B$, Annexe, 1957.

Dionysius Byzantius, Anaplus Bospori, ed. Rud. Güngerich. Berolini, 1927; 2nd ed., 1958. 
Eitrem, art. Io ('I $\omega ́)$, $R E 9$ (1916), 1732-1743.

R. Engelmann, art. Helena, Roschers Lexikon d. Myth., $\mathrm{I}^{2}$ (1886-90), 1968-78.

一, art. Io, Roschers Lexikon d. Myth., II ${ }^{1}$ (1890-93), 263-280.

A. Fick, Die ehemalige Spracheinheit der Indogermanen Europas. Eine sprachgeschichtliche Untersuchung. Göttingen, 1873. [Thracian -para is considered to be present also in Bóoropos.]

—, "Altgriechische Ortsnamen," $B B 21$ (1896), 268f., 283; 22 (1897), 11, 61, 63, 67, 97 [on Bбблоро५, p. 11]; 23 (1897), 226; 24 (1899), 295 [on Thracian -para and Gr. $\pi$ ópos].

P. Friedländer, art. Helle 2, RE 8 (1912), 159-163.

Vladimir Georgiev, "La toponymie ancienne de la Peninsule Balkanique et la thèse méditerranéenne," $L B$ 3, 1 (1961), 5-62. [II. Région thrace, 9-11; some 41 examples with - para and similar; six more are added to these by Georgiev but are rather doubtful.]

—, "Hellespontos and Bosporos," LB 3, 2 (1961), 25-27.

L. Grasberger, Studien zu den griechischen Ortsnamen. Würzburg, 1888. [On Bóблopos,







Paul Haupt, "Philological and Archeological Studies," AJP (1924), 238-259. [Under




With a reservation, Haupt's interpretation is accepted by V. Burr, Nostrum mare (1932), p. 12 note 5: "vielleicht ist 〈die neue Deutung von Haupt〉 richtig."] I am very much indebted to the Kahanes for their gracious help in locating this item for me as well as to Dr. Athanasios Papadopoulos (London).

R. Hoernes, "Die Bildung des Bosporus und der Dardanellen," SB d. Akad.d. Wiss. Wien, mathem.-naturw. Kl., Abt. 1, vol. 118 (1909), 693-758. [Superseded by the following.]

-, "Das Bosporusproblem," SB d. Akad. d. Wiss. Wien, mathem.-naturw. Kl., Abt. 1, vol. 120 (1911), 1087-1111.

E. B. J., art. Bosporus Thracius, W. Smith (ed.), A Dictionary of Greek and Roman Geography (London, 1878), 422b-424b; idem, art. Bosporus Cimmerius, ibid. 421b-422b; idem, art. Hellespontus, ibid. 1038b-1039a.

Günther Jachmann, "Der Name Hellespont," RhM 70 (1915), 640-644.

Norbert Jokl, art. Thraker. B. Sprache, Eberts RLV 13 (1929), 278-298. [On the linguistic matters, 284-296; on -para, -pera 285b und 289a.]

Alfred Klotz, "Über die Bedeutung des Namens Hellespont bei den Geographen," $R h M$ 68 (1913), 286-296. Cf. Jachmann.

P. Kretschmer, Einleitung in die Geschichte der griechischen Sprache. Göttingen, 1896. [Die thrakisch-phrygischen Stämme, 170-243; Stellung der thrakisch-phrygischen Sprache, 217-243. On - $\pi \alpha \rho \circ 5,-\pi \alpha \rho \alpha$, p. 221.] Cf. A. Fick, [review of this book] BB 24 (1899), 295.

—, "Literaturbericht für das Jahr 1935. Griechisch," Glotta 27 (1939), 29. [On the names



Albin Lesky, Thalatta; der Weg der Griechen zum Meer. Vienna, 1947.

-, "Hellos-Hellotis, III," Wiener Studien 46 (1927/28) 107-129. [On goddess Helle and Hellespontos, pp. 127-129.]

F. Machatschek, Das Relief der Erde (Berlin, 1955), 12. 509f. [Die Balkanhalbinsel; das Bosporusgebiet.]

L. Malten, "Motivgeschichtliche Untersuchungen zur Sagenforschung III. Hero und Leander," RhM, N.F., 93 (1949/50), 65-81. [On Bosporos and Hellespont, $71 \mathrm{ff}$;; "E $\lambda \lambda \alpha$ and $\Phi \omega \sigma \varphi b \rho \circ$, 79; etc.; also bibliography is listed on p. 71 note 23.] 
A. M. Mansel, art. Hellespontos, Der Kleine Pauly 2 (1967), 1010-1012.

A. Merz, "Die Strömungen des Bosporus," Bibliothek Geographischer Handbücher, N.F., Festband Albrecht Penck (Stuttgart, 1928), pp. 277-295.

-, "Die Strömungen von Bosporus und Dardanellen," Verhandlungen des 20. Deutschen Geographischen Tages Juni 1921, pp. 106-112. [These two items by A. Merz are superseded by the following item, especially chapter B. Die Strömungen, pp. 99-152.]

-, Hydrographische Untersuchungen in Bosporus und Dardanellen, bearbeitet von Lotte Möller. (Veröffentlichungen des Instituts für Meereskunde, Univ. Berlin, N.F., A. Geographisch-naturwissenschaftliche Reihe, H. 18.) Berlin, [1928]. 284 pp. Also atlas. [The author Alfred Merz made his observations in the Bosporus 22 Sept. to 14 Oct. 1917, 6 May to 5 June 1918, and 19 June to 21 July 1918. The observations by Merz at 186 stations in the Bosporus and 115 stations in the Dardanelles are listed on pp. 233-284. After his death in 1925 Lotte Möller worked out the data. Cf. the chapter "Morphologie und Geologie der Meerengen. A. Bosporus" (pp. 38-41) and "B. Dardanellen" (41-44). Their joint work remained the standard treatise on the Bosporus up to 1946 (cf. Ullyott and Ilgaz in this bibliography).]

E. Meyer, art. Bosporos (Bóблtopos) 1, Der Kleine Pauly 1 (1964) $933 \mathrm{f}$.

E. Oberhummer, art. Bosporos, $R E 3$ (1899), 741-757.

一, art. Hellespontos, RE 8 (1912), 188-193.

Oxford English Dictionary, s.v. Hellespont.

W. Penck, "Bau- und Oberflächenformen der Dardanellenlandschaft," Zeitschrift der Gesellschaft für Erdkunde (Berlin), 1917, pp. 30-49.

-, Grundzüge der Geologie des Bosporus. Berlin, 1919. (Veröffentlichungen des Inst. $f$. Meereskunde, N.F., A. Geograph.-naturwiss. Reihe, 4.) 71 p. Geologische Kartenskizze des Bosporusgebietes. [Das Bosporustal, 58-69. Summary, 68f.]

A. Philippson, "Bosporus und Hellespont," $G Z 4$ (1898), 16-26. [A lecture; also comparison of the Bosporus valley with the Rheintal; p. 17 note 1, five items of bibliography on Bosporus; p. 23 note, three on the Hellespont. The whole superseded by his Das Mittelmeergebiet ${ }^{4}$ (1922); cf. also R. Hoernes and W. Penck.]

-, Kleinasien, in Handbuch der regionalen Geologie 5, 2, Heft 22 (Heidelberg, 1918), 183 pp.

-, Das Mittelmeergebiet; seine geographische und kulturelle Eigenart ${ }^{4}$. Leipzig, Berlin, 1922. [Die Mittelmeerzone eine Bruchzone, 6-7; Erosionstäler des Hellespont und Bosporus, 18-21 ; Flußtäler des H. und B., 44; die Strömungen im B. und H., 52; etc.]

Theodore Reinach, "Le Bosphore chez Eschyle," REG 36, No. 164 (1923), 62-65; idem, ibid., $349 \mathrm{f}$.

G. Rohlfs, "Flußnamen im heutigen Kalabrien," $B N F, N F, 4$ (1969), 114-142.

A. Ronconi, "Per l'onomastica antica dei mari," SIFC 9 (1931) 193-242 and 257-331. [Il Bosforo, 220-225; Ellesponto e Propontide, 225-242. Cf. Burr, above.]

W. H. Roscher (ed.), Ausführliches Lexikon der griechischen und römischen Mythologie. 6 vols in 9. Leipzig-Berlin, 1884-1937. $\mathrm{I}^{1}$ (1884-85), I $\mathrm{I}^{2}$ (1886-90), II ${ }^{1}$ (1890-93), II ${ }^{2}$ (1894-97), III ${ }^{1}$ (1897-1902), III $^{2}$ (1902-09), IV (1909-15), V (1916-24), and VI (ed. K. Ziegler) (1924-37). Suppl. I (E. H. Berger), 1904. Suppl. II (O. Gruppe), 1921. [Articles: R. Engelmann on Io $\mathrm{II}^{\mathbf{1}}$, coll. 263-280; K. Seeliger on Athamas $\mathrm{I}^{\mathbf{1}}$, coll. 669-675; R. Engelmann on Helena, $\mathrm{I}^{2}$, coll. 1977f.; K. Seeliger on Helle, $\mathrm{I}^{2}$, coll. 2028 f.; Türk on Phrixos, $\mathrm{III}^{2}$, coll. 2458-2467.]

Martin Rudolph, ПОРО $\Sigma$. Marburg, 1912. [Discussion in Latin of the development of the word through almost the entire Greek literature with a rich collection of the


by O. Becker, "Das Bild des Weges usw."]

K. Seeliger, art. Helle, Roschers Lexikon d. Mythol., $\mathrm{I}^{2}$ (1886-90), 2028-2029.

-, art. Athamas, Roschers Lexikon d. Mythol. $\mathrm{I}^{\mathbf{1}}$ (1884-85), 669-675. 
W. Sieglin, "Die Ausdehnung des Hellespontes bei den antiken Geographen," Beiträge zur alten Geschichte und Geographie. Festschrift für Heinrich Kiepert (Berlin, 1898), 323-331. [On the sea stretches which the name Hellespont designated in the ancient authors, who display five coverages. The author presents all pertinent statements and interprets them. The matter was investigated anew by A. Klotz and some important corrections were made (see A. Klotz, $R h M$ 68 [1913], 286-296, and A. Ronconi, SIFC 9 [1931], 225-242.)

William Smith (ed.), A Dictionary of Greek and Roman Geography (London, 1878), s. vv. Bosporus Cimmerius, Bosporus Thracius, Hellespontus.

George R. Stewart, American Place-names. New York, 1970.

P. de Tchihatcheff, Le Bosphore et Constantinople. Paris, 1864. 3rd ed., 1877.

Wilhelm Tomaschek, Die alten Thraker. Eine ethnologische Untersuchung. I: Übersicht der Stämme, SB d. philos.-hist. Cl. d. k. Akad. d. Wiss. Wien, 128 (1893), IV. Abhandlung, pp. 1-130; II: Die Sprachreste. 1. Hälfte: Glossen aller Art und Götternamen, ibid., 130 (1894), II. Abhandlung, pp. 1-70; 2. Hälfte: Personen- und Ortsnamen, ibid., 131 (1894), I. Abhandlung, pp. 1-103. [To a large degree superseded by the work of D. Detschew. 130.16: on $-\pi \alpha \rho \circ \varsigma,-\pi \alpha \rho \alpha,-p h a r a$; 131.63: names in -para, -pera, $-\pi \alpha \rho \circ$ s.] $^{2}$

N. Tunçdilek et alii, art. Bosporus, $E B r 3$ (1970), 985b-986a.

-, art. Dardanelles, $E B r 7$ (1970), 73. [A map shows the exact length of the strait of the Dardanelles.]

Türk, art. Phrixos, Roschers Lexicon d. Mythol., III' (1902-1909), 2458-67.

Philip Ullyott and Orhan Ilgaz, "The Hydrography of the Bosporus: An Introduction," $G R 36$, No. 1 (1946), 44-66. [An excellent review of the hydrographical investigations with bibliography and presentation of the authors' theory. The authors have refuted the explanation of the movements of the waters of the Bosporus propounded by Alfred Merz and Lotte Mölleras untenable; the subsurface current never reaches the Black Sea.]

K. Vlahov, "Das thrakische Wort PARA und seine Deutung," Živa Antika (Antiquité Vivante) (Skopje) 15 (1966), 295-304.

\section{INTRODUCTORY}

Sucction UCCESSFUl RESEARCH of GEOGRaphic Names has to go hand in hand with topography, geography, history, and in certain instances with geology. A case in point is the waterway between the Aegean (and the Mediterranean) Sea and the Black Sea, consisting of the Hellespont (the Dardanelles), the Propontis (Sea of Marmara), and the Bosporos, and the names covering them. There are valid grounds for requiring parallel examination and interpretation of these names: (a) the geologic formation of the entire waterway centered at the Propontis, (b) the very fact that the name Bosporos was used for the straits of the Hellespont, for the straits at Byzantion, and for the Cimmerian straits (the straits of Kerch), (c) that both the Hellespont and the Bosporos were associated with a myth, the former with Helle and the latter with Io transformed into a cow, and (d) the fact that the name Hellespontos at some time covered even all of the Propontis. Both these names, as well as that of the Cimmerian Bosporos, are attested very early and are more than 25 centuries old. 
The geographical configuration of Southeast Europe includes the straits of the Hellespont, the in-between Propontis, and the Bosporos. These waterways are parts of one system, having geographic and hydrographic features in common, and constitute the only access to a large, otherwise landlocked sea. Their extraordinary aspect is that no case analogous to this can be found anywhere else on earth. ${ }^{1}$ When searching minds pressed on the quest for the causes of the origin of the straits, the geographic question turned into a geological problem. ${ }^{2}$ It is now common scientific knowledge that both the Hellespont and the Bosporos are maritime rivers with two water currents, one deep below the surface flowing from the Aegean toward the Black Sea but not reaching into it and a second one on the surface flowing from the Black Sea in the opposite direction. As to their origin, according to geological investigations, the Bosporos and the Hellespont are not tectonic forms but were erosion valleys which once were inundated by the sea and were, in fact, submerged and transformed through marine erosion into what they are now. ${ }^{3}$ What happened is this: the Pontus Basin was an inland lake till the middle diluvium (middle pliocene); in the upper pliocene period a large stream cut the Bosporos furrow and into it the Bosporos valleys and the Hellespont valleys. The Bosporos and the Hellespont as well as the Euripos of Chalcis of Euboea can be explained only as submerged river valleys; for no other power, according to geologists, could create furrows of this kind. ${ }^{4}$

Among the intriguing aspects of the seaways are the water currents flowing both ways. The main surface current flows NNE to SSW from the Black Sea to the Sea of Marmara, and this southward current in the Bosporos is strong enough to hinder the passage of small craft northward. ${ }^{5}$ The subsurface current, called kanal by local boatmen and fishermen, ${ }^{6}$ flows along the floor of the Bosporos from the Sea of Marmara toward the Black Sea; the kanal in the deeper layers of the Bosporos and the greater salinity of its water than that of the surface current are confirmed realities. The surface layer of the water in the Sea of Marmara

1 A. Philippson, GZ 4 (1898), 16.

2 Cf. W. Penck, Grundzüge der Geologie des Bosporus (1919), p. 5.

3 See A. Philippson, W. Penck, S. von Bubnov, F. Machatschek, and others; see bibliography.

4 A. Philippson, Das Mittelmeergebiet ${ }^{4}$ (1922), p. 21.

6 Cf. P. Ullyott and O. Ilgaz, "The Hydrography of the Bosporus: An Introduction," $G R 36$ (1946), p. 44. On the adverse effect of the intermittent northeasterly winds on the southward current and on sailing Greek triremes in ancient times see B. W. Labaree, "How the Greeks Sailed into the Black Sea," AJA 61 (1957), pp. 29-33.

6 The Turk. term kanal in the Bosporus (attested as early as 1656), borrowed from Venetian canal "channel," designates the bed of the main current and kanal suyu (lit. "channel water") the deep current flowing toward the Black Sea; see H. and R. Kahane and A. Tietze, The Lingua Franca in the Levant (Urbana, Ill., 1958), p. 136f. (No. 146). 
has low salinity (ca. 24 parts per 1,000) and is like the water of the Black Sea, while the deeper water has a higher salinity (ca. 39 parts per 1,000) all year round. The lower layer water of the Sea of Marmara flows northward along the bed of the channel; but the depth of the undercurrent in the Bosporos progressively diminishes toward the north and none of it enters the Black Sea, the same amount of flowing water being carried back southward in the upper current, mixed with water from the Black Sea. ${ }^{7}$ There is a system of flow in the Kerch strait very much like the one in the Bosporos.

The balance of water in the Black Sea seems to be complete without any inflow through the Bosporos, according to Ullyott and Ilgaz. But the deep water of the Sea of Marmara is constantly depleted and is replenished by the inflow of water at a depth from the Aegean Sea. The threshold at the Dardanelles between the Aegean and the Sea of Marmara, being deep enough (ca. $65 \mathrm{~m}$.), permits the flow of deep water from the Aegean. ${ }^{8}$

The Bosporos has the following measurements: length $30 \mathrm{~km}$. $(27 \mathrm{~km}$. in a straight line), width between $550 \mathrm{~m}$. and $3 \mathrm{~km}$., and depth an average of $50 \mathrm{~m} .^{9}$

The Dardanelles seaway was originally almost dry, so that Europe was connected with Asia Minor and the strait represented a wide river valley. ${ }^{10}$ The straits of Nagara and Çanak, at which the European and Asiatic shores are as close to each other as $1.2 \mathrm{~km}$., separate the inner from the outer Dardanelles. ${ }^{11}$

The straits between the NE Aegean and the Black Sea have also been the traditional boundary line between the two continents, Europe and Asia. They played a highly important role throughout the past as the channel connecting the Black Sea and the Mediterranean and as a bridge between Anterior Asia and SE Europe; here the continental masses lie within a few hundred meters of each other and enabled peoples and armies to cross from continent to continent, so that they were spared risky seafaring; with the development of navigation, the straits assumed enhanced significance because the seaway from the Atlantic led through

7 The evidence is that the salinity in the surface water of the Bosporos increases as it moves southward, i.e., it is produced by progressive incorporation of the water of the saline current with that of the surface current. For the above see Ullyott and Ilgaz, op. cit., pp. 44-66; conclusion, p. 65f. For earlier views on the currents see A. Philippson, Das Mittelmeergebiet ${ }^{4}$ (1922), p. 52; here also on the flows (currents) in the Strait of Gibraltar.

8 Ullyott and Mlgaz, loc. cit.

9 Philippson, GZ 4 (1898), p. 20; cf. A. Merz, Hydrographische Untersuchungen (1928), p. 38 .

${ }_{10}$ F. Machatschek, Das Relief der Erde (Berlin, 1955), p. 510 [according to W. Penck].

11 Cf. Merz, op. cit., p. 41. 
these Straits as far as the inland parts of the continental mass called the Old World. ${ }^{22}$

The history of the straits is interrelated with Greek history since the Greek colonization of the area. While Greek colonization in the west started in the mid-eighth century (Kyme in Campania was founded by colonists from Chalcis of Euboea ca. 750 B.C. and a series of settlements appeared in Sicily a little later in the same cent.), the great colonization activity of Miletus (itself founded in the eleventh cent. B.C. and called the Greek Venice) reached the Sea of Marmara and the coasts of the Black Sea soon after 700 B.C. and strove toward the peak of its colonization activities in the mid-seventh century. An important point for our discussion here is also that the earliest of these sea voyages have, here and there, influenced the evolvement of the sagas; e.g., the penetration of Ionic seafarers into the Black Sea determined the scene of the Argonautic Expedition. Conceptions originally mythological are subsequently filled with geographical ingredients. ${ }^{13}$

After this orientation, we may tackle the onomastic data and the names Hellespontos and Bosporos.

The statement to the effect that etymologizing onomastic items is a dangerous business and also that the paucity of sources has often enabled scholars to etymologize hand-picked onomastic data to suit vaguely


are two cases in point.

\section{A. HELLESPONTOS}




designation for both the Propontis (Sea of Marmara, Turk. Marmara Denizi) and the Dardanelles, including part of the outside sea opening toward the Aegean, but since the fifth century B.C. confined to the Dardanelles. ${ }^{15}$ The narrows are to the Turks Çanakkale Boğazı and inter-

12 W. Penck, op. cit., p. 5.

13 Cf. A. Lesky, Thalatta (1947), pp. 61, 188.

14 J. Puhvel, (review of D. Detschew's Thrakische Sprachreste), Language 33 (1957), pp. 441 and 443.

${ }^{15}$ On the Hellespont in general see A. M. Mansel, art. Hellespontos, Der Kleine Pauly 3 (1967), pp. 1010-12 [with the most important literature cited]; L. Bürchner, art. Hellespontos, $R E 8$ (1912), pp. 182-188; E. Oberhummer, ibid., pp. 188-193. The Byz. name




stretch east of Lampsacus as far as the line Perinthus-Cyzicus, and (3) the unit of both the strait and the entire Propontis. See A. Ronconi, "Ellesponto e Propontide," SIFC 9 (1931), pp. 225-242 (an exhaustive study); V. Burr, Nostrum mare (1932), pp. 11-21 (almost adequate). Cf. also A. Klotz, $R h M 68$ (1913), pp. 290-292; G. Jachmann, RhM 70 (1915), pp. 640-643 [a Hellenistic poet added the use of 'E $\mathrm{E} \lambda \lambda \dot{n} \sigma \pi \circ v \tau o s$ for the Aegean Sea]. A description of the Hellespont is given also by Strabo 13.1.22-23; Dionys. Byz., 
nationally the Dardanelles and the Straits of Gallipoli. ${ }^{16}$ Other names were: Stretto della Romania (fifteenth cent.), Bucca Romaniae, Golfo di Gallipoli, $\Sigma \tau \varepsilon v o \grave{v} \tau \tilde{\omega} \nu \Delta \alpha p \delta \alpha v \varepsilon \lambda \lambda i \omega v$, all for "the seaway of the Dardanelles."












They are, despite Georgiev, ${ }^{18}$ not real names but varying transformations employed in the creative process of poetry.

Various early etymologies are not worth discussing today. ${ }^{19}$




which in fact occurs in an adespoton fragment, yielded the one-word




strait at Abydos was also a real name.

P. Kretschmer's etymological exposition $(1939)^{20}$ was sanctioned by the authors of both Greek etymological dictionaries, ${ }^{21}$ but the interpreta-












Pauly 3 [1969], 82 b). However, since there was $K \alpha \lambda \lambda i$ iro $\lambda_{\iota \varsigma}$ in Aetolia (called also $K \alpha^{\prime} \lambda \lambda$ เov), in Macedonia, and in Italy near Tarentum (now Gallipoli), also our city name K $\alpha \lambda \lambda_{\text {เoúto }} \lambda_{15}$ in the Hellespont became by analogical interference $K \alpha \lambda \lambda i \pi 0 \lambda \iota s$, and this form is reflected as early as the thirteenth century: Pertinentia Gallipoli, in: Partitio Romaniae, ed. G. L. Fr. Tafel und G. M. Thomas, Urkunden zur ältesten Handels- und Staatsgeschichte der Republik Venedig, Theil 1 (Wien, 1856), p. $467 \mathrm{f}$., where it is recorded as Gallipoli from $\tau \dot{\eta} \nu \mathrm{K} \alpha \lambda \lambda i \pi 0 \lambda \iota \nu$


Galliparo (infra, p. 97). The Turk. name form for Gallipoli is Gelibolu. The inhabitant name $\mathrm{K} \alpha \lambda \lambda \iota \pi 0 \lambda_{i} i n s$ occurs in the thirteenth and sixteenth cent. (Marie Vogel und Victor Gardthausen, Die griechischen Schreiber des Mittelalters und der Renaissance [Leipzig, 1909], pp. 238, 286).



18 V. Georgiev, "Hellespontos und Bosporos," $L B$ 3, 2 (1961), p. 25.

19 They are indicated by V. Burr, Nostrum mare (1932), p. 12, note 5 (Seliger and Höfer in Roscher; Gruppe and Oberhummer, rejected by Friedländer; Bürchner's connecting of



${ }^{20}$ Cf. E. Schwyzer, Griechische Grammatik, 1.446 (H. Kuhn, BNF 4 [1953], p. 171 f., on the compounding with a genitive in Germanic place-names); P. Kretschmer, "Literaturbericht für das Jahr 1935. Griechisch," Glotta 27 (1939), p. 29.

${ }^{21}$ Frisk, $G E W 1$ (1960), p. 500 [the relevant installment publ. in 1957]; Chantraine, Dict. etym. 2 (1970), p. 341. 
tion has been questioned by three other scholars, who instead postulated other solutions, which are to be discussed here.

At least two etymologies of the name " $E \lambda \lambda \eta$ as pre-Hellenic were in fact based on some elements of the myth discussed earlier by scholars.

Prehellenic origin of the name "E $\lambda \lambda \eta$ from *hella "north" (this from *hela "fog, north"), whence also *Hellane "Nordic people" $\rightarrow$ "E $\lambda \lambda \alpha \nu \varepsilon \varsigma$,



First of all, the etymology here is not really one that was built up by the author's independent linguistic insights but has derived from an opinion previously held by others: I mean, Lauer in the nineteenth century explained "E $\mathrm{E} \lambda \eta$ as "shining cloud." ${ }_{23}$ Now, as is well-known,


which means "Cloud." This "cloud" redundancy does not really enhance Deroy's interpretation. If objectively and carefully examined and evaluated, Deroy's proposal is hardly supported by data (which are nonexistent) but is based on imaginative projections. My objection to this suggestion is as follows: the naming process is not an exclusive one but the naming of geographic features is unpredictable and the naming of a given place may have been one of hundreds of possibilities. To be sure, names from the concept "fog" are not uncommon in foggy regions, e.g., Foggy Island in Alaska (at which Sir John Franklin was detained by fog in 1826 for eight days); but Foggy Peak in the state of Washington (U.S.A.) was so named probably because of fog encountered on a particular day. ${ }^{24}$ However, though other places are foggier and more northerly than the Hellespont, we would not necessarily expect such areas like Scandinavia, England, Canada, Russia, etc., to have received their names from terms meaning, "very cold," "northern," "foggy," etc. In placenames each case has to be examined for itself on the basis of evidence. Helle and Hellespont may be northern relative to Greece and Asia Minor but, in a general geographic picture, are really not. If we had evidence for the designation "north," I would agree; as it is, I find no validity in this attempt.

The name "E $\mathrm{\lambda \lambda \eta}$ was interpreted in 1837 to signify "swamp" and "moist soil" (" $\left." \lambda . \varsigma_{5}\right){ }^{25}$ In our century two scholars, Paul Haupt and Vladimir Georgiev, have used the same attempt in different ways.

${ }^{22}$ L. Deroy, "L'origine préhellénique de quelques noms de peuples méditerranéens," Annuaire de l'Institut de Philol. et d'Hist. Orientales et Slaves 13 (Bruxelles, 1955), pp. 90-92.

${ }^{23}$ Lauer, Systematik der griechischen Mythologie, p. 216; see K. Seeliger, art. Helle, Roschers Lexikon d. Mythol., I² (1886-90), p. 2029.

${ }^{24}$ Cf. G. R. Stewart, American Place-names (1970), p. 169.

${ }^{25}$ So P. V. Forchhammer, Hellenika (1837), p. $177 \mathrm{ff}$; cf. K. Seeliger, loc. cit.; in part also Ed. Gerhard, Griechische Mythologie, § 688 (cf. Seeliger, ibid.). 
Paul Haupt suggested in 1924 that "E $\mathrm{\lambda} \lambda \eta$ may be a name in $-\eta$ like


(Il. 20.221; cf. Strabo 7.7.10). ${ }^{26}$ However, the author did not elaborate and so left more questions unanswered than solved; e.g., where are the parallel formations in $-\eta$ from neuter es-nouns ? Moreover, the geminate $\lambda \lambda$


show no trace of $\lambda \lambda$ from $* \lambda y, * \lambda \nu, * \lambda \sigma$, etc. In addition, the Mycenaean ethnic ereeu does not support such a relationship. As is well known, tò


*selesyo- ${ }^{27}$

V. Georgiev's attempt may have been based on an identical suggestion as a starting-point, as indicated above. Georgiev holds that the age-old


folk-etymology ${ }^{28}$ but I miss cogent reasons leading to such a conclusion.


of swamps" (wherein "E $\lambda \lambda \eta$ s with - $l l$ - is explained away by paretymological influence of the Greek name "E $\lambda \lambda \eta$, which he derives from IE *swel-);


this from *selos-, seles- "swamp" with $h$ - (in both Greek and Phrygian)


name for the river in the Troas emptying into the Hellespont. ${ }^{29}$ The name is, according to Georgiev, Phrygian, not Greek, and, in the same line


Phrygian, meaning "river, stream"; the genuine Phrygian toponym,


Bó $\sigma-\pi o p o s "$ leads us to conclude, he says.

It appears that Georgiev's etymology is refutable. To begin with, the sense "stream, river" assigned to the alleged Phrygian term tópos (on


is nothing certain, for there is no Phrygian evidence in sight; when Herodotus calls the strait "a turbid and a briny river" (7.35) nothing is proved by this for two reasons: first, Herodotus immediately after this quotation calls the Hellespont a sea $(\tau \dot{\eta} \nu \tau \varepsilon \delta \dot{\eta} \theta \dot{\alpha} \lambda \alpha \sigma \sigma \alpha \nu \nu \lambda \lambda)$ and, sec-


sea." Herodotus actually calls the Hellespont a river in the passage quoted from Xerxes' allegedly verbatim message to the Hellespont, which he

${ }^{26}$ Paul Haupt, "The Hittite Name of Troy," in his "Philological and Archeological Studies. 7," AJP 45 (1924), pp. 252-255 [the entire study on pp. 238-259]. Haupt's suggestion was favored with some caution by V. Burr, Nostrum mare (1932), p. 12, note 5, who, however, did not present it to his own readers.

${ }^{27}$ Cf. H. Frisk, GEW 1 (1960), p. 501 f.; P. Chantraine, Dict. etym. 2 (1970), p. 342; J. Pokorny, $I E W$ 901, s. selos-.

28 LB 3 (1961), p. 25.




will yoke with a bridge (as if the Hellespont were a river); to Xerxes the strait looked like a (salty) river on account of its length. Furthermore, the adjective áráppoos "strong-flowing" used for the Hellespont (Il. 2.845, 12.30) may or may not imply a river, since póos stands for


and Crete is called $\pi \varepsilon p i p p u \tau o s$ "surrounded with water" (Od. 19.173). ${ }^{30}$ Of course both the Hellespont and the Bosporos are maritime rivers; however, the term rópos is so abundantly attested in Greek of all periods




Phrygian or otherwise without unequivocal evidence. Georgiev has not advanced such evidence and the record is unshakable. The postulated adj. 'E $\mathrm{\lambda} \eta \mathrm{s}$ from *seleswents presumes that Phrygian had exactly the


Greek form be ascribed to Phrygian?

The idea that the name "E $\mathrm{A} \lambda \eta$ can in some way be explained linguistically within Greek was persistent with some nineteenth-century scholars, when the adoption of antique etymologies was easy and etymological method left much to be desired. Thus, based on the Etymologicum Magnum, there are three different etymologies: "E $\lambda \lambda \eta$ would be from a


"Strehlke" (in German). ${ }^{31}$ In the same line of thinking, "E $\lambda \lambda \eta \eta$ would be connected with "E $\mathrm{\lambda} \varepsilon^{\prime} \mathrm{\eta} \eta$ because this latter name was explained from $\sigma F \varepsilon \lambda$ (Skt. svar-) in $\sigma \varepsilon \lambda \eta^{\prime} \nu \eta$ "moon." $32 \sum \varepsilon \lambda \eta \eta \eta \eta$ is a Greek moon-goddess and


Etym. M. 828.15); $\Sigma \varepsilon \lambda \dot{n} \sim \eta$ had little cult in Greece; she was identified with Artemis, probably before the fifth cent. B.C., perhaps because both had been identified with Hecate. ${ }^{33}$ 'E $\mathrm{e}$ év Greek name and several aspects about her fit an ancient, pre-Hellenic goddess. ${ }^{34}$

We now know that "E $\mathrm{E} \lambda \eta$ is etymologically unrelated to $\sigma \varepsilon \lambda \lambda^{\prime} \nu \eta$ or to


moon-goddess (like $\Sigma \varepsilon \lambda \eta_{\eta}^{\prime} \nu \eta$ and 'E $\mathrm{\lambda} \varepsilon^{\prime} \nu \eta$ ) is a hypocoristic of the name "E $\lambda^{\varepsilon} v \eta$, this meaning "moon," is a repetition of worthless nineteenthcentury method and opinions. His argument that Etym. M. 549.18

30 A. Ronconi, SIFC 9 (1931), pp. 226-228.

31 Pape-Benseler, 1.351a; K. Seeliger, Roschers Lexikon d. Mythol., 2029, who also stresses that "we may at least explain Helle as sun, for this is considered in classical mythology throughout as a male being" (ibid.).

${ }^{32}$ G. Curtius, Grundzüge der griechischen Etymologie 5(1879), p. 552; Pape-Benseler, 1.344 ; R. Engelmann, art. Helena, Roschers Lexikon d. Mythol., col. 1977.

33 Pape-Benseler, 2.1364; W. H. Roscher, Über Selene und Verwandtes (1890); cf. J. E. Fontenrose, art. Selene, $O C D^{2}(1970)$, p. $970 \mathrm{f}$.

${ }^{34} O C D^{2}$ (1970), p. $492 \mathrm{f}$. 
equates $\varepsilon \lambda \lambda \eta \eta$ with $\sigma \varepsilon \lambda \eta \dot{\nu} \eta$ and $\ddot{\eta} \lambda$ เos and that the name "E $\lambda \lambda \eta$ has, therefore, yielded the noun $\varepsilon^{\prime \prime} \lambda \lambda \eta{ }^{35}$ simply does not hold true; it still represents the indiscriminate pre-linguistic throwing together of flagrantly unrelated terms to prove indemonstrable combinations. For the truth is as follows:

$\sigma \varepsilon \lambda \eta^{\prime} \nu \eta$ is from $\sigma \varepsilon \lambda \alpha \dot{\alpha} \nu \bar{\alpha}: \sigma \varepsilon \varepsilon_{\alpha \varsigma}$



"E $\mathrm{E} \lambda \eta \eta$ is certainly not from 'E $\mathrm{E} \lambda \mathrm{\varepsilon}^{\prime} \eta$ this in turn being of unknown origin.

All the above attempts must be considered unsatisfactory.

\section{Is there an explanation?}

Before any new attempt, though a tentative one, we had better clarify some thoughts about Helle in the myth from what has been found out or attempted by scholars.

"E $\mathrm{E} \lambda \bar{\alpha}$, an old goddess, was identified with the deity of light who was worshipped on the shores of the Hellespont and Bosporos, i.e., the deity



From another viewpoint, Helle was rather a goddess thought of, in the same situation, riding on a male animal as Europa rode on the back of a bull across the sea. ${ }^{37}$ Helle is placed by A. Lesky in the group of Hellos -




as the author concedes, the very late tradition of Helle causes a critical examination of this mythical figure to appear extremely difficult. ${ }^{39}$ The author has also stressed ${ }^{40}$ the statement that Helle appears steadfastly connected with the Hellespont.

Helle in the fleece saga of Athamas, Nephele, and the ram is of but subordinate significance ${ }^{41}$ and the connection of the entire myth of Athamas-Nephele-ram with the Argonaut saga is held to have been sec-

35 A. Chatzis, "'E $E \lambda \eta-" E \lambda \lambda \eta \nu-~ ' E \lambda \lambda \alpha \varsigma^{\prime}, " ~ E E \Phi \Sigma$ of the Univ. of Athens 1 (1937), pp. 135-38; on the above, p. 137 with note 3.

36 Cf. L. Malten, "Hero und Leander," $R h M, N F, 93$ (1949), p. 79 (with references to U. v. Wilamowitz-Moellendorff).

37 This assumption by O. Gruppe (Griechische Mythologie und Religionsgeschichte, [1906], p. 1146) is considered probable by A. Lesky, "Hellos-Hellotis, III," Wiener Studien 46 (1927-28), p. 129. The story of Phrixos and Helle voyaging through the air on the back of the golden-fleeced ram, a marvelous and intelligent beast, is best connected with the tale of Pegasos' journey; so C. Kerényi, The Heroes of the Greeks (1959), p. 85.

38 Lesky, loc. cit.

39 Ibid., p. 127.

40 Ibid., pp. 127-129.

41 Cf. K. Seeliger, Roschers Lexikon d. Mythol., 2029. 
ondary. ${ }^{42}$ This, however, does not entail that Helle's figure was spun out of the geographic name Hellespontos as an eponymous heroine, as Müller thought ${ }^{43}$ and as this explanation, fixed in Roscher's Lexikon der Mythologie, continued. ${ }^{44}$ If this were really the case, then we still have


was; in other words, we are in a vicious circle.

The only reasonable and plausible solution in sight is to assume that

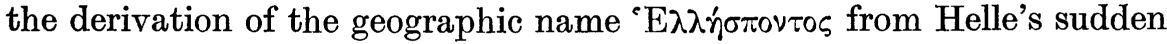
fall into the waters of the strait presents a characteristic aition for the place so named. ${ }^{45}$ Analogous is the motif of Daidalos and Ikaros and the


"Icarian Sea." The inclusion of Helle in the story is, in comparative mythology, explained by L. Radermacher from parallel folk tales. ${ }^{46}$

The aforementioned Chatzis elaborated about "E $\lambda \lambda \eta$ as follows: a city called "E $\mathrm{\lambda} \lambda \eta$ and located in the Thracian Chersonese on the shore at the strait of the Hellespont, after Homer renamed П $\alpha x \tau$ in by Ephesian

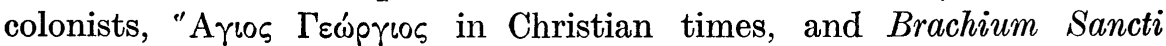
Georgii among Westerners in the Middle Ages, was named "E $\lambda \lambda \eta$ after the temple of Helle there. ${ }^{47}$ The question arises whether or not the temple was primary and the name of the city secondary. According to P. Friedländer, a tomb-like looking hill was designated as Helle's tomb after the relevant saga had become well established and Helle's mythical figure was later inserted into the body of the saga. ${ }^{48}$

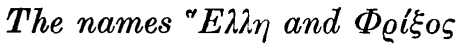



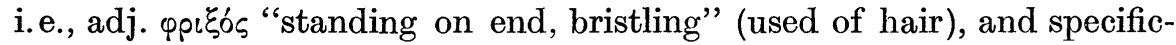
ally as a shortened form of compounds such as $\varphi p_{i} \xi_{0} \theta_{p l} \xi$ and $\varphi p i \xi o x o ́ \mu \lambda s$, these latter both meaning "with bristling hair," 49 so that the name $\Phi^{\prime} \hat{\zeta}_{\text {os }}$

42 H. D. Müller, Mythologie der griechischen Stämme, 2 (1861), p. 158ff.; cf. Seeliger, op. cit., p. $673 \mathrm{f}$.

43 Müller, op. cit., 2.165.

44 Lesky, Wiener Studien 46 (1927-28), 129 note 50, stamps this explanation unfortunate.

45 Cf. H. Hunger, Lexikon der griechischen und römischen Mythologie (1953), p. 275.

${ }^{46}$ L. Radermacher, Mythos und Sage bei den Griechen ${ }^{3}$ (Vienna, 1943), p. 181 f., pointed out that the folk tale of the little brother and little sister, in which a lamb, a ram or a sheep plays a role, is widespread even in today's folk tales; cf. Hunger, op. cit., s. Phrixos, p. 276.

47 So O. Gruppe, Griechische Mythologie und Religionsgeschichte (1906), 1.565 note 7 (with references); followed by Chatzis, op. cit., p. $135 \mathrm{f}$.

48 P. Friedländer, art. Helle 2, RE 8 (1912), 160f. - Chatzis (op. cit., 138) states ideas derived from Friedländer and modified.




would mean "Curly," 50 we do not have an equally good explanation for

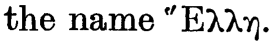

In any case, we would be wise to adhere to a traditional explanation of

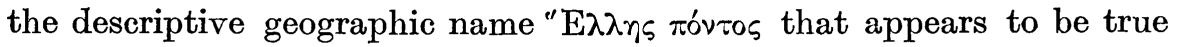
to fact: "Helle's sea." 51 We are appreciative of the fact that we have received the cherished precious tradition we now have; unduly to question facts at our disposal and to substitute for them fanciful reconstructions that add almost nothing to knowledge goes too far, indeed.

However, if we should have one tentative explanation for the name "E $\mathrm{\lambda} \lambda \eta$, the only one seeming probable to me is that linking the name with the term for "young deer, fawn," so that "E $\mathrm{\lambda} \lambda \eta$ would originally mean

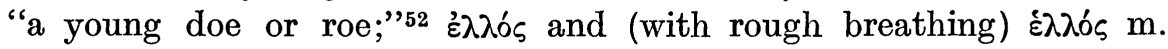
"a young deer, fawn" (Od. 19.228; ef. the mythographer Antoninus Liberalis [second cent. A.D.] 28.3;53 Eustathius, Comm. ad Hom. 1863.40;

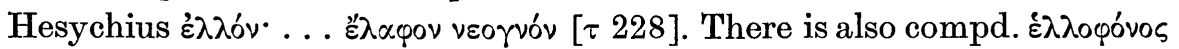
"fawn-slaying": Callim. Diana, 190).

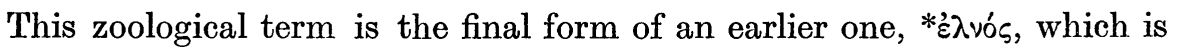
warranted in Indo-European by Lithuanian élnis "stag"; see also the



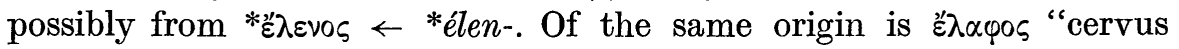

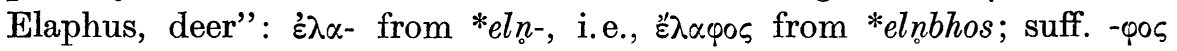
(from *-bhos) as in épt-pos. ${ }^{54}$

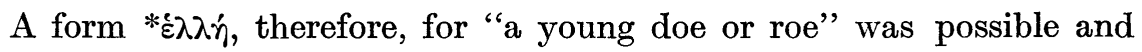
might have existed before it fell into disuse because the form "e $\lambda \propto \varphi_{\circ} \mathrm{f}$. prevailed; yet, it lingered on as an endearing name ${ }^{55}$ or nickname of girls.

If this attempt is not convincing, the name "E $\mathrm{E} \lambda \eta \eta$ must be declared of obscure origin.

In closing, the following reasonable assumption may be in order: "E $E \lambda \eta \eta$ was the name of the promontory on the Thracian Chersonese at the entrance to the strait of the Dardanelles and after this place-name the

50 C. Kerényi, The Heroes of the Greeks (1959), p. 85. The meaning "he who causes shivering" (from $\left.\varphi p^{\prime} \sigma \sigma \omega\right)$ in L. Radermacher, op. cit., p. 312 (cf. also Hunger, Lexikon, s. Phrixos, p. 275) is made to fit more the mythical than it appears natural or actual.

51 As Chantraine, Dict. etym., s. "E $\mathrm{\lambda} \lambda \eta$, most recently put it, " $\Pi$ n'y a aucune raison de renoncer à l'interpretation traditionnelle depuis l'antiquité 'mer d'Hellè'."

52 Cf. Kerényi, op. cit., p. 86.

53 E. Martini (ed.), Mythographi Graeci, 2 (1) (Leipzig: Teubner, 1896), p. 107, 1. 21.

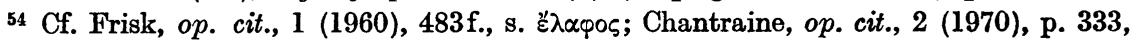








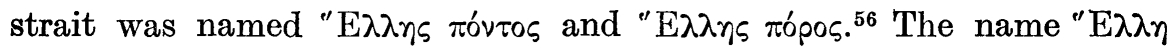
was on the Thracian Chersonese but the saga used the name aetiologically. ${ }^{57}$ But beyond this we know nothing certain about the name "E $E \lambda \eta$.

\section{$\Delta \alpha \varrho \delta \alpha v \varepsilon ́ \lambda \iota \alpha$ - The Dardanelles}

The modern name dardanélya has reached international status and thus to a large extent replaced the ancient name:

\section{Italian: Dardanelli}

French: les Dardanelles

Spanish: Dardanelli

English: the Dardanelles ${ }^{58}$

German: die Dardanellen

Russian: Dardanélli (gen. plur. Dardanéll; adj. Dardanéll'skiy) etc.

The medieval and modern Greek name $\tau \dot{\alpha} \Delta \alpha \rho \delta \alpha \nu \varepsilon^{\prime} \lambda \lambda_{\iota} \alpha$, the source of these forms, has been with good reasons linked with the ancient city

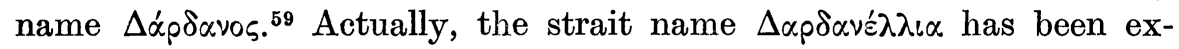

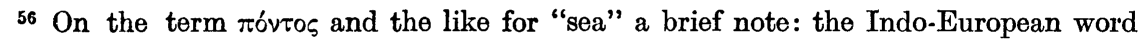
*mari "sea" is missing in East Indo-European (Sanskrit, Greek, and Armenian). On the terms $\theta \dot{\alpha} \lambda \alpha \sigma \sigma \alpha, \alpha^{\prime} \lambda \varsigma, \pi o ́ v \tau o \varsigma$, and $\pi \dot{\varepsilon} \lambda \alpha \gamma \circ \varsigma$ cf. A. Lesky, Thalatta (1947), pp. 8-14. I take exception to the vague interpretation of $\theta \dot{\alpha} \lambda \alpha \tau \tau \alpha$ as pre-Hellenic: in view of the (presumed Macedonian) form $\delta \alpha \lambda \alpha \gamma \chi \alpha$ "sea" in Hesychius the approach of $\theta \dot{\alpha} \lambda \alpha \sigma \sigma \alpha$ with $\theta \alpha \lambda \alpha$ - (in

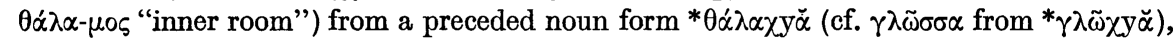
used presumably for inner waters, is to me very probable; C. D. Buck, " $\Theta \alpha \dot{\alpha} \alpha \sigma \sigma \alpha$, , Classical Studies Presented to Edward Capps (Princeton, 1936), pp. 42-45 (this study is not mentioned by P. Chantraine, Dict. étym., 2.420a, and H. Frisk, GEW, 1.648f., knows it only from the notice in Indogerman. Jahrbuch 22.220.); cf. E. Schwyzer, Griechische Grammatik 1 (1939), p. 3197, who suggested the earlier form was $\theta \dot{\alpha} \lambda \alpha \gamma \chi y \alpha \breve{~ o n ~ a c c o u n t ~ o f ~ M a c e d o n i a n ~}$ $\delta \alpha \lambda \alpha \gamma \chi \alpha \alpha_{\nu}\left(\sigma \sigma / \tau \tau\right.$ results from both $-\chi y^{-}$and $\left.-\gamma \chi y^{-}\right)$. W. Steinhauser's setup of IE *salakyə "salt water" $\rightarrow$ Pelasgian śalaśs $\bar{a} \rightarrow$ Gr. $\theta \dot{\alpha} \lambda \alpha \sigma \sigma \alpha$ and IE $d h o l-\partial n-k \bar{a}$ "the one that finds itself below, depth" $\rightarrow$ Pelasgian dalankha ("Zwei Wege der Wortdeutung," Gedenkschrift für P. Kretschmer 2 [1957], 152-154) is a failure because it splits $\theta \dot{\alpha} \lambda \alpha \sigma \sigma \alpha$ and $\delta \alpha \lambda \alpha \gamma \chi \alpha$ and works with too many imaginary forms.

${ }^{57}$ Cf. the analysis of the saga in P. Friedländer, art. Helle 2, $R E 8$ (1912), 161; and in C. Kerényi, The Heroes of the Greeks (London, 1959), pp. 85-87, and notes 429-443 [on p. 391]; cf. also art. Helle, Der Kleine Pauly 2 (1967), 1008. - Herodotus (7.58) mentions "the tomb of Athamas' daughter Helle."

58 The name Dardanelle and Dardanelles in the United States became popular for California mines in the 1850's and the cause of the naming was either transfer of the name or a fancied resemblance to the strait. The name is now used in the United States for The Dardanelles and associate names in California and for places in other states. Dardanelle in Arkansas, on the other hand, originally derived from the French family name Dardenne but it is supposed to have been attracted to the form of the name of the straits. See G. R. Stewart, American Place-names (1970), $127 \mathrm{f}$.

59 The strait of the Dardanelles was named after the city name $\Delta \alpha \operatorname{p} \delta \alpha v \circ \varsigma$ according to Karl Kerényi (Die Heroen der Griechen [Darmstadt, 1959], p. 99), who, however, for 
plained from $\Delta_{\alpha \rho}^{\prime} \delta \alpha v^{\prime} \lambda \lambda \iota \alpha \sigma \tau \varepsilon v \alpha$ as a derivative adjective from a hypo-

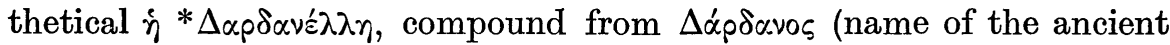
city on the southern, the Asiatic side) and " $E \lambda \lambda \eta^{60}$ (at the Thracian extremity). According to Chatzis, ${ }^{61}$ the name $\tau \dot{\alpha} \Delta \alpha \rho \delta \alpha \nu \varepsilon \lambda_{\lambda} \lambda \iota \%$ for the strait was in use, along with 'E $E \lambda \hat{n}$ ' $\sigma \pi \circ \nu \tau \circ$, for centuries by the neighboring peoples. The author, however, left out of consideration a very important fact: "E $\mathrm{\lambda} \lambda \eta$ was on the extreme Thracian promontory at the entrance to the Hellespont but ancient $\Delta \alpha \dot{\rho} \delta \alpha v o s$ was located many kilometers away to the northeast, below the narrowest central section on the Asiatic side in the Troas, which renders the assumption of the dvandva compound unlikely. One would have expected the two names to be those of points opposite one another, such as Nagara and Çanak, Abydos and Sestos, at the narrowest point of the Hellespont. The interpretation is highly improbable.

The name $\tau \dot{\alpha} \Delta \alpha p \delta \alpha v \varepsilon \lambda_{\lambda} \lambda \iota \alpha$ for the city (Turk. Çanak-kalesi "pottery castle"), with a present population of about 25,000 , on the Asiatic side at the mouth of the river Rhodios (Turk. Sarzçay), at the narrowest point of the strait and facing ancient Kuvòs $\sigma \tilde{n} \mu \alpha$ in the Thracian Chersonese, is, I submit, a neuter derivative with the diminutive suffix $-\varepsilon_{\varepsilon}^{\prime} \lambda_{l} 6^{62}$

reasons unknown to me, omitted this statement from the English edition (The Heroes of the Greek [London, 1959], p. 86f.) of his book. The city called Dardanos appears on the coast in a little bay on the south end of a little peninsula; see W. Judeich, "Skepsis," Festschrift H. Kierpert (Berlin, 1898), map, figure 1, on p. 228. - On the Homeric city Dardania (Il. 20.215ff.), erected by Dardanos, alleged mother city of Tlion, and transferred from Ida to Scamander see Judeich, op. cit., p. 239. On the connection of $\Delta \alpha \rho \delta \alpha \nu \varepsilon^{\prime} \lambda \lambda_{\imath \iota \alpha}$ with the city $\Delta \alpha \dot{\alpha} \delta \alpha \nu \circ \zeta$ cf. more recently $\mathrm{N}$. Tunçdilek et alii, $E B r 3$ (1970), p. 73.

What in names has not, to my knowledge, been mentioned before and may be of interest to some is the fact that in Modern Greek there are surnames: $\Delta \alpha \dot{\alpha} \delta \alpha v o s$ (thrice), $\Delta \alpha p-$ $\delta \alpha \dot{v \eta n s}$ (twice), and $\Delta \alpha \rho \delta \alpha v^{\prime} \delta \eta{ }^{\prime}$ (once), listed in the Athens Telephone Directory 1966 (the much shorter telephone directory of Salonica and the rest of the northern region, which I consulted, does not list these names).

${ }_{60}$ Demetrios Pelekidis and A. Chatzis in the latter's article, $E E \Phi \Sigma$ of the Univ. of Athens 1 (1937), p. 136 with note 3. Parallel examples were cited: $\tau \dot{\alpha}$ Mo $\theta \omega x b \rho \omega v \alpha, \dot{\eta} \Pi \alpha \rho \circ-$

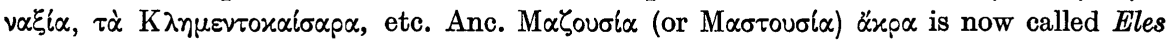

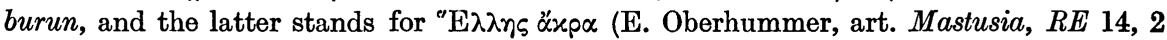
[1930], 2178); Cape Helles is found on maps (English sea map N 1608: Entrance of the Dardanelles; Kiepert; Diest. Cf. Oberhummer, ibid.). Chatzis' assumption that "E $\mathrm{\lambda} \lambda \eta$ had also the meaning "Peninsula of Helle" (op. cit., 136) is unsupported and needless.

61 Ibid., note 3.

62 The suff. - $\varepsilon \lambda \lambda_{l}$ is well known in the eastern modern Greek dialects. The name form Dardanelo is recorded for the locality of Kale Sultanijeh "The Sultan Castle" (this created ca. 1470), located not far from Dardanos; see W. Tomaschek, "Zur historischen Topographie von Kleinasien," $S B d$. Wiener Akad., 124, 8 (1891), p. 17. If Ital. Dardanello was used by sailors, as it seems, the Greek form $\tau \dot{\alpha} \Delta \alpha \rho \delta \alpha v \varepsilon \varepsilon^{\prime} \lambda \iota \alpha$ would be a Greek adaptation of the corresponding Italian plural Dardanelli.

If anyone wonders about the hypocoristic form Dardanello, he may consider that hypocoristic forms are not strange at all; e.g., beside the Italian river name Salandra (today 
from the name $\dot{\eta} \Delta \alpha \dot{\alpha} \delta \alpha v o s$ of the ancient city, which is located some ten kilometers southwest of the modern city $\Delta \alpha \rho \delta \alpha \nu \varepsilon^{\prime} \lambda_{l} \alpha_{.}{ }^{63}$ It was, then this medieval and modern name that yielded the designation $\Sigma \tau \varepsilon v \dot{\nu} \nu \tau \tilde{\omega} \nu$ $\Delta \alpha \rho \delta \alpha \nu \varepsilon \lambda \lambda^{i} i \omega \nu$ "Strait of the Dardanelles," an exact parallel of the Strait of Gallipoli (cf. also Peninsula of Gallipoli), drawn likewise from a city name $\mathrm{K} \alpha \lambda \lambda i \pi 0 \lambda \iota \varsigma_{\text {, }}$ this being no dvandva either.

\section{B. BOSPOROS}

The waterway between the Propontis and the Black Sea offers another example, interesting from the onomastic point of view, of multiple names during its nearly 3,000 year-long history. It is called Karadeniz


is called also Vósporos in the Greek of the Greek-speaking people living

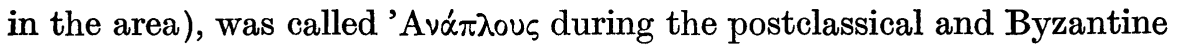

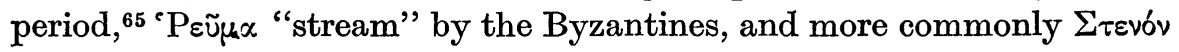

officially Cavone) in the area of Metaponto (Lucania) there occurs Salandrella, name for its upper flow; the river name Galatrella in the province of Cosenza is diminutive of gálatru "burrone" (from anc. Gr. $\chi \alpha \dot{\alpha} \rho \alpha \delta \rho \circ \varsigma)$. See G. Rohlfs, "Flußnamen im heutigen Kalabrien," $B N F, N F, 4$ (1969), 117 notes 5 and $6 ; 126$.

${ }^{63}$ The city $\dot{\eta} \Delta \alpha \dot{\alpha} \delta \alpha \nu \circ \varsigma$ existed in the province of Hellespontos as late as the sixth century A.D.; Hierocles, Synecdemos, 662.7, ed. E. Honigmann (Bruxelles, 1939), p. 23. Cf. L. Bürchner, art. Dardanos 1, RE 4 (1901), $2163 \mathrm{f}$.

${ }^{64}$ Cf. V. J. Parry, art. Boghaz-iči, EIsl 1 (1960), 1251 a-1252b; Besim Darkot and M. Tayyib Gökbilgin, art. Boğaziçi, Islâm Ansiklopedisi 2 (1944-49), 666-692. The narrows at the south end of the Bosporos are called Marmara Boğazı; see the Atlas of Turkey, prepared by Ali Tanoğlu et alii (Istanbul, 1961), map 1/a: Istanbul and map 1: Türkiye. Cf. Atlas of the World, vol. II (1959), plate 37: Dardanelles; on the Karadeniz

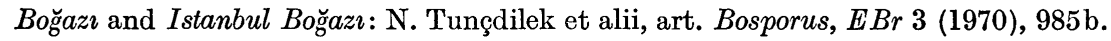

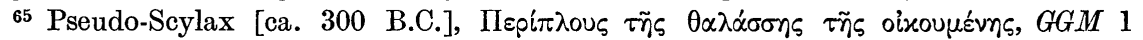




Up the Thracian Bosporus), ed. R. Güngerich (Berlin, 1927; ${ }^{2} 1958$ ): 'Avó $\pi$ iovs for Dionysius Byzantinus was (1) the entire Bosporos and (2) the place called 'Eotía


the church to the archangel Michael, erected by Constantine the Great and renewed with magnificence by Justinian); cf. the scholiast [tenth cent.] ad Dion. Byz. 21.8. Cf. R. Güngerich, op. cit., p. XLV f. Then, Dionys. perieg. [first / second cent. A.D.], GGM 2

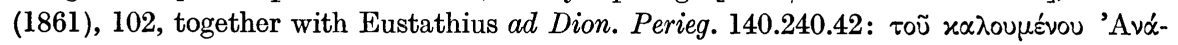

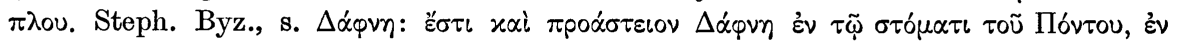

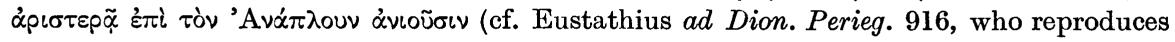
this information from Steph. Byz.); Steph. Byz. s. K $\alpha \lambda \lambda i \pi 0 \lambda \iota s: K \alpha \lambda \lambda i \pi 0 \lambda \iota s, \pi 0 \lambda i \chi_{\nu} \eta$

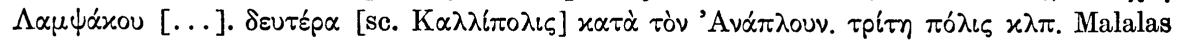
[sixth cent., before A.D. 563], Chronographia, 78.8. There is the site on the European bank of the Bosporos called 'Avá $\pi \lambda_{0 u \varsigma}$ (Procopius, De aedif., 1.8.2; 6; 17); in Procop., op. cit., 1.5.1, 'Av'́x $\pi$ ous is the suburb of Byzantion on the site of the modern suburb called

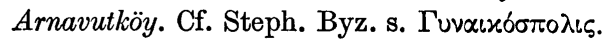


"narrow, straits";66 it was Brachium Sancti Georgii to the Latins at the time of the Crusades, the same name as that for the Hellespont, and since ancient times the name has been Bóoropos/bósporos, in modern Greek vósporos $/ .67$ This age-old name of the straits at Byzantion, meaning "channel" (or even "crossing") was given about the early seventh century B.C. ${ }^{68}$ Bosporos and Bosporus has been the international designation for these straits. Some additional substitute terms for it were used in antiquity but these described a geographic reality and did not really become names in their own right. ${ }^{69}$

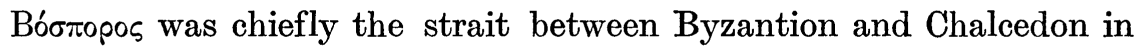

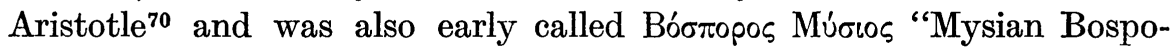

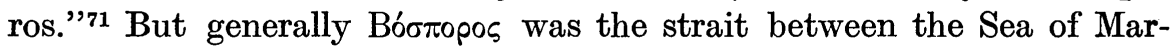

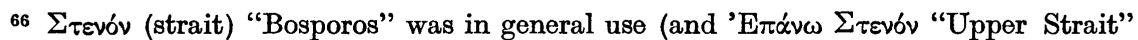

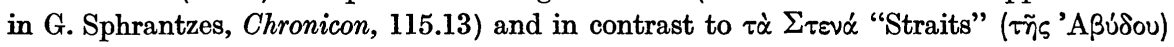

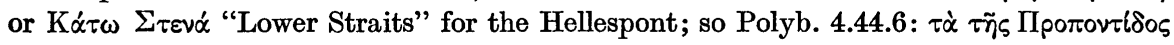

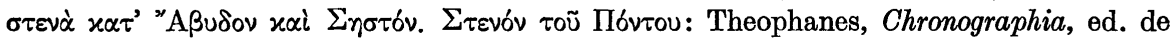

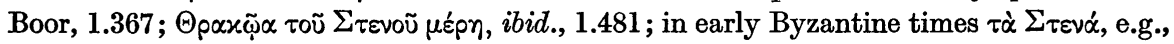

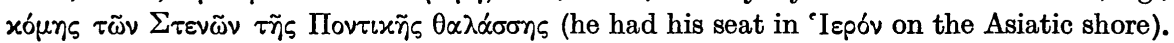

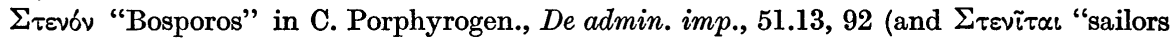

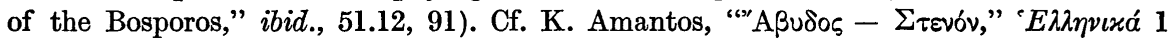

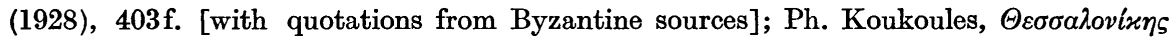

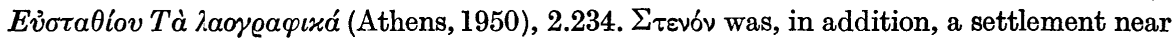
the City. Cf. also D. Zakythinos, $E E B \Sigma 22$ (1952), 179f. Hence the name Stenum in the Partitio Romaniae (1204); Tafel und Thomas, Urkunden 1 (1856), p. 473 note 7.

As a parallel there may be mentioned Narrows (used as a singular form; cf. $\tau \dot{\alpha} \Sigma \tau \varepsilon v \alpha$ ) in the United States, which designates a narrow place in a generally broader body of water; hence the name The Narrows and (as a habitation) Narrows in the state of Virginia. See G. R. Stewart, American Place-names (1970), p. 318.

67 The Russian forms of the name are Vospór from middle Greek Vósporos and Bospór and Bosfór, new borrowings from medieval Latin Bosporus and Bosphorus (Bosforus); cf. M. Vasmer, Russisches etymologisches Wörterbuch 1 (1953), 111, s. Bospór. The accent on the last syllable (Vospór, Bospór) of the Russian reflex for Greek Vósporos or Latin Bósporus, not explained by Vasmer, is an internal linguistic matter, the result of innerRussian practice about names of foreign provenience; this was the result of my discussion of this matter with my colleagues Eugene Grinbergs (Univ. of North Dakota) and Dr. Jaroslav Rudnyćkyj (Univ. of Manitoba).

68 On the early date of Bosporos' naming cf. V. Burr, Nostrum mare (1932), p. $27 \mathrm{f}$.

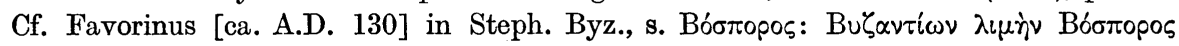
$\varkappa \alpha \lambda \varepsilon \tilde{i} \tau \alpha$.

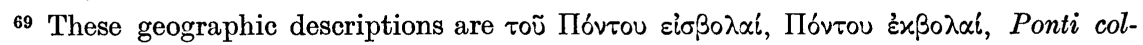
lum, Ponti canalis, Ponti fauces (Ovid, Tristia, 1.9.31). Cf. GGM 2.6; E. Oberhummer, art. Bosporos 1, RE 3 (1899), 755; Burr, op. cit., p. 24. On Turkish descriptive names for "Bosporos" see Parry, op. cit., 1251 b.

70 Aristotle, meteor. 1.14.30; 3.2.6; anim. hist. 8.15.4.

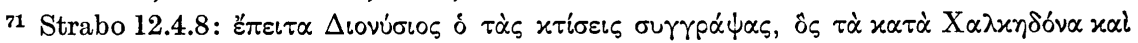

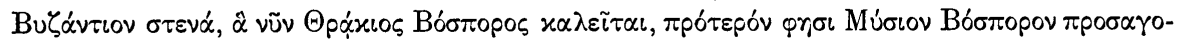

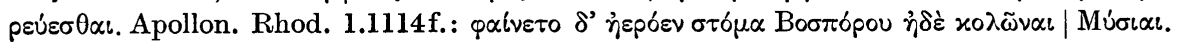
Schol. Apollon. Rhod. 2.168. 


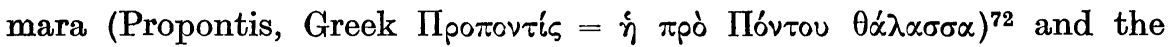
Black Sea (Pontos). ${ }^{73}$

The first attestations of the name Bóoropos are found in Herodotus

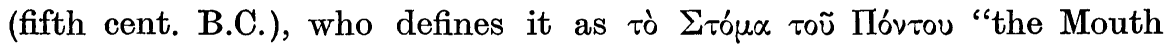
toward Pontos" and, in its broader sense "the entire strait," as evidenced

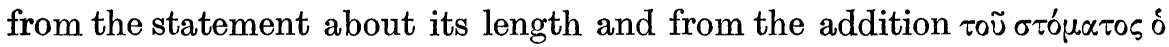

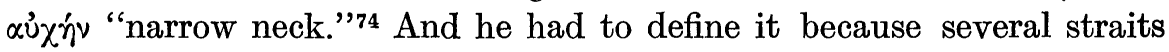
in the NE Mediterranean bear the name Bóoropos; e.g., Aeschylus [fifth cent. B.C.] employed the same name for the Hellespont and the Cimmerian strait. The Bosporos in the area of Byzantion is called

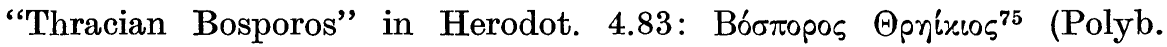

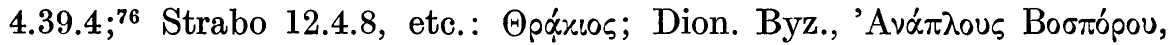

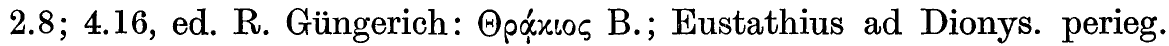
140: ఆpaxuxós) and in Latin literature Bosporus Thracius or Bosporus, ${ }^{77}$ spelled also Bosporos and Bosphorus. The contrast usually is to the strait

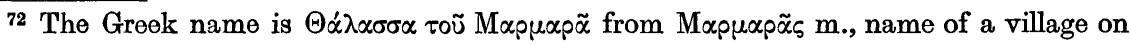
the island of Prokonnesos, this latter located at the northern exit of the Hellespont.

${ }^{73}$ According to Polybius, who offers a description of the Bosporos (4.43f.), the southern boundary line, i.e., the beginning, of the (Thracian) Bosporos was the strait between Chalcedon and Byzantion (Polyb. 4.39.5) and the northern end point toward the Black Sea was the so-called 'I 1 póv (4.39.6, now in Turkish Yoros). Cf. F. W. Walbank, $A$ Historical Commentary on Polybius, vols. 1, 2 (Oxford, 1957, 1967), on Polyb. 4.39 .5 and 6.

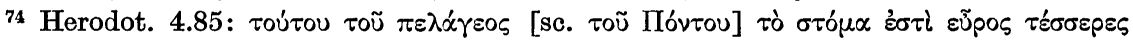

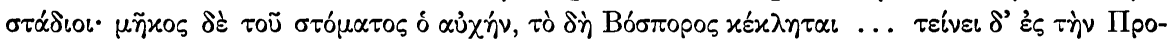

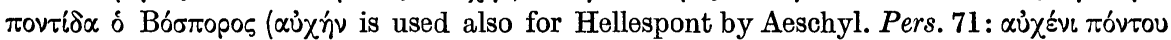

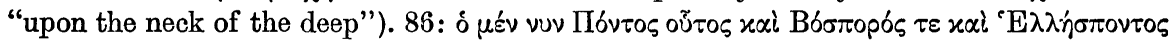

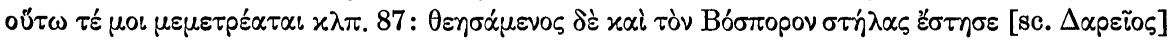

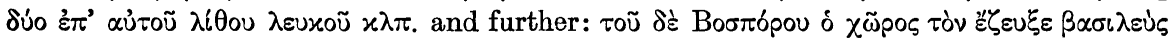

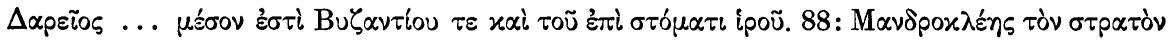
$\alpha \cup \tau o \tilde{~} \delta\left\llcorner\alpha \beta \alpha i v o v \tau \alpha \ldots \dot{\alpha} \mathcal{\varepsilon}^{\prime} \theta \eta \eta \varepsilon\right.$. The bridge of boats set up by order of Darius to facilitate the crossing over the Bosporos for his campaign against the Scythians was perhaps at the narrowest point at Rumeli Hisar.

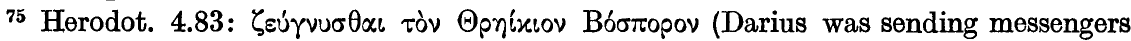
to charge some men to bridge the Thracian Bosporos); 7.10: $\pi \alpha$ iǹ ó oòs [sc. Darius, Xerxes'

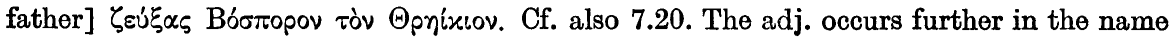

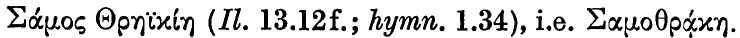

${ }^{76}$ On the Thracian Bosporus see also the comments and bibliography in Walbank,

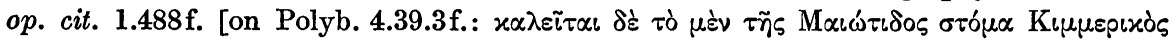

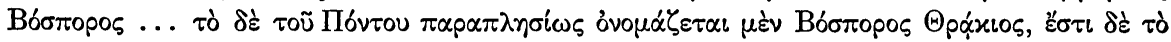
$\mu \dot{\nu} \mu \tilde{\eta} \varkappa 0 \varsigma x \lambda \pi$.]. On the personal viewing by Polybius of the Thracian Bosporos see C. M. Danoff, art. Pontos Euxeinos, RE, Suppl., 9 (1962), 883.

77 Varro [ca. 37 B.C.], Res rust., 2.1.8, ed. Goetz (Teubner, 1929): Bosporum unum Thracium, alterum Cimmerium; Mela [ca. A.D. 40] 1.14; Pliny [ca. A.D. 23-70], $\mathrm{NH} \mathrm{4.76;}$ etc. Bosporos: Lucanus [mid-first cent. A.D.], 5.436, ed. Housman (Oxford, 1916); Bosphoros: Ovid, Tristia [written A.D. 9-12], 3.4.49, ed. Owen (OCT, 1915). - Cf. ThLL, s. Bosporus, 2 (1900-06), 2143 ff. [with derivatives]; J. Perin, Onomasticon, in: Ae. Forcellini, Lexicon totius Latinitatis 5 (Patavii, 1940), 277; Oxford Latin Dictionary, fasc. 1 (1968), 240a, s. Bosp(h)orus. 


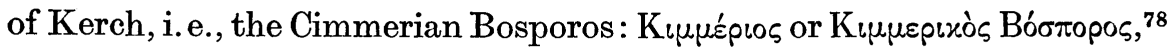
in Latin Bosporus Cimmerius, and less so to the Hellespont. ${ }^{79}$

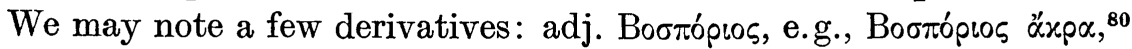

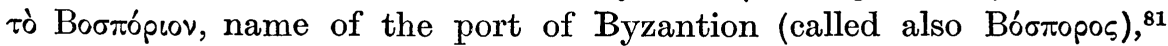

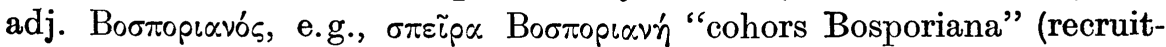
ed principally from the inhabitants of the B. Cimmerius), 82 and inhabitant name Booropíns referring to B. Cimmerius (year 268 B.C.), ${ }^{83}$ but also to the B. Thracius. ${ }^{84}$

\section{Folketymological name forms:}

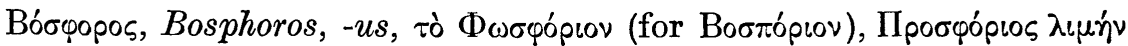

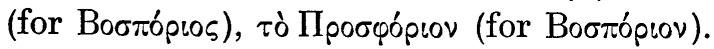

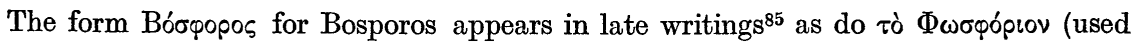

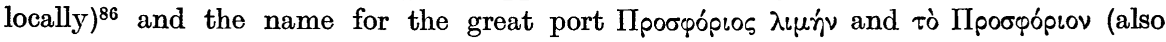

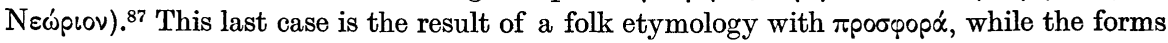
with - $\varphi$ - (Bóøøopos) or with $\Phi$ - $\varphi$ - came about as the outcome of the interference of ' $\mathrm{E} x \alpha \dot{\alpha} \tau \eta$

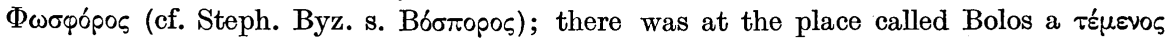

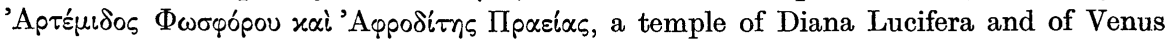
Placida, where the inhabitants of Byzantium offered sacrifices annually. ${ }^{88}$

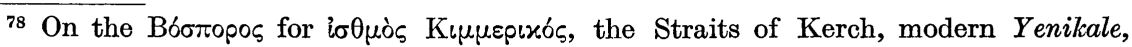

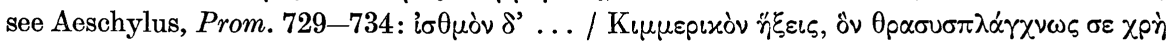

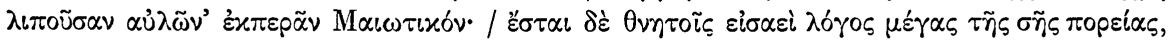

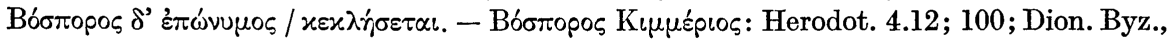

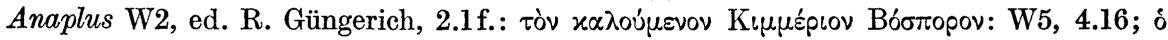

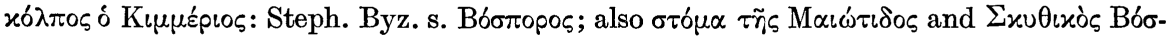

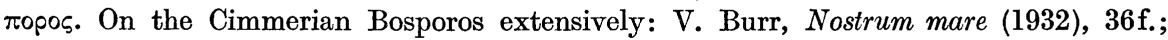
cf. also E. B. J., art. Bosporus Cimmerius, in: W. Smith (ed.), A Dictionary of Greek and Roman Geography (1878), $421 \mathrm{bf}$.

79 Cf. Servius, ad Georg. 3.152 (Bosphoros = Hellespontus).

${ }^{80}$ Dionys. Byz., Anaplus Bospori (ed. R. Güngerich), p. 3, 1.2-3; 4.1; 4.10; 13.1; $16.16 ; 22.13$.

81 Herodiani technici reliquiae, ed. A. Lentz (Leipzig, 1867), 1.365.35.

${ }^{82}$ W. Dittenberger, Orientis graeci inscriptiones selectae 2 (1960), p. 122, inscr. 489, 1. 7 [the inscription was found at the mouth of the Hermos, $3 \mathrm{~km}$. from ancient Phocaea

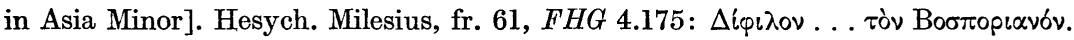

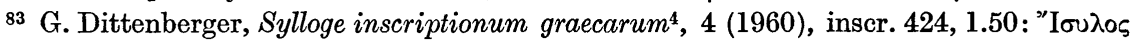

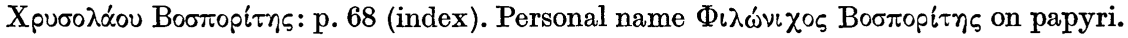



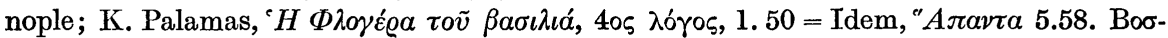

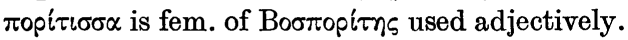

${ }_{85}$ Schol. Flor. Eurip. Med. 1; ap. Asterium, p. 180, E cod. Combef.; Georg. Syncellus,

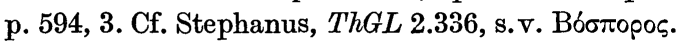

${ }^{86}$ Steph. Byz., s. Bóoropos; Eustathius ad Dionys. perieg. 142; Hesych. Milesius, fr. 26, FHG 4.151.

${ }^{87}$ R. Janin, Constantinople byzantine (Paris, 1950), pp. 241 and 275; cf. R. Guilland, "La chaîne de la Corne d'Or," EE B 25 (1955), pp. 99 and 104.

88 Dionys. Byz., Anaplus Bospori, ed. R. Güngerich, p. 16, 1. 4f.; cf. Petri Gellii, De Bosporo Thracio, II, 6, p. 32 (in the same ed. by Güngerich). See also Phosphorus in Güngerich, p. 28, 1. 10. 
The Latin equivalent forms are Bosphoros, ${ }^{89}$ Bosphorus (also Bosforus), ${ }^{90}$ Thracius Bosphorus, ${ }^{91}$ Cimmerius Bosphorus, ${ }^{92}$ and Bosphoros $=$ Hellespont. ${ }^{93}$ The lexica also reflect these forms..$^{94}$ From the Latin form derive the forms in western European languages: Bosphorus is found in early English and German writings, the French form Bosphore, Ital. Bosforo, Span. Bòsforo, etc. In Greek itself, however, the sporadically occurring form Bóopopos has not survived as such probably because it was not used orally but rather only by copyists of manuscripts ( $\varkappa \omega \delta \iota \varkappa о \gamma p \alpha ́(\rho)$ ) who were familiar with the folk etymologies and the Latin form Bosphorus (and Bosforus).

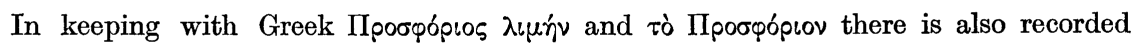
Portus Prosphorius in Latin. ${ }^{95}$

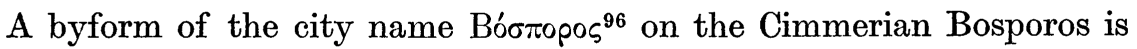

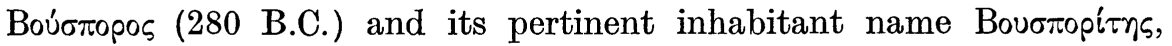
occurring in a dedicatory inscription of Isyllus from Epidaurus in Argolis, ${ }^{97}$ instead of Bóoropos; this seems to me to be the result of analogical

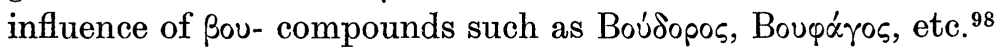

\section{The Interpretation}

There have been advanced a few possible explanations for the name Bóoropos, one in the Thracian language, one in Phrygian (originally a dialect of Thracian), and another in Greek.

89 Bosphoros: Ovid, Tristia, 3.4.49, ed. Owen (OCT, 1915).

90 Bosphorus: Varro, Res rust., 2.1.8; Horace, Carm. 2.13f. (with schol. Valer. Flacc. 4.344; 419); Curtius [mid-first cent. A.D.], 6.12.13, ed. Hadicke (Teubner, 1908); Müller, GGM 2.7 note 7.

91 Mela [written ca. A.D. 40], De chorographia, 1.7; 1.14 (ed. Frick, Teubner, 1880); Pliny [ca. A.D. 23-70], $N H$ 4.76; 92; etc. (cf. Solinus [ca. mid-third cent. A.D.], 12.2, ed. Mommsen, 1895; Julius Honorius, Cosmographia, recensio A 28: mare Bosphorus Thracius (GLM, ed. Riese).

92 Mela 1.7; Pliny, $N H$ 4.76; etc.

93 Servius [fourth/fifth cent. A.D.], ad Georg. 3.152, ed. G. Thilo (Leipzig, 1887): [Io] transiit ... per mare angustum, quod Bosphorom appellatum est, nunc Hellespontum nominatur.

94 ThLL 2.2143: Borphorus Bosforus in libris usitatior (bosforus in: Notae Tironianae, 110.79, ed. Schmitz, 1893: Commentarii notarum Tironianarum. Perin, Onomasticon (1940), 277; Oxford Latin Dictionary 1 (1968), s. Bosp(h)orus.

${ }^{95}$ Cf. Janin, op. cit., pp. 241 and 275; Guilland, $E E B \Sigma 25.98 f$., 104.

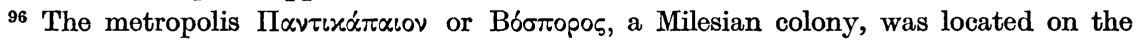

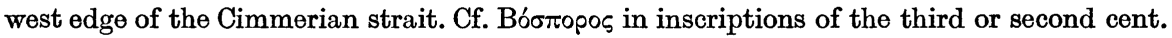
B.C.: H. Collitz, Sammlung der griechischen Dialekt-Inschriften (Göttingen, 1884-1915), Nos. $3086.5 ; 3087.10 ; 32 ; 35$.

97 Die argivischen Inschriften von W. Prellwitz, in: Collitz, ibid., No. 3342, 1. $62=I G$

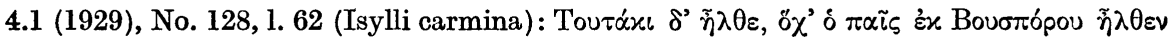

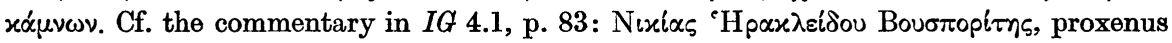
at Delphi, $277 / 6$ or $276 / 5$ B.C.

98 On the form Boboropos see below, p. 91 with note 126. 


\section{a. THRACIAN AND PHRYGIAN}

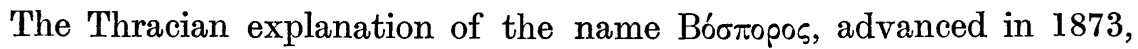
has been held to seriously for three reasons: (1) the descriptive name

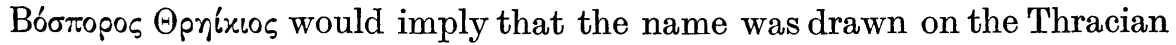
language, (2) there are names (and only place-names) in -para (and [the irrelevant] -poris) in Thracian, ${ }^{99}$ and a Byzantine fortress called Bospara (sixth cent. A.D.), ${ }^{100}$ and (3) folk etymology at work by the first Greek

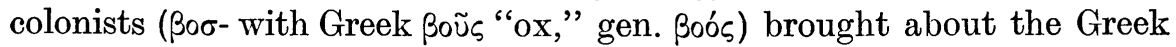

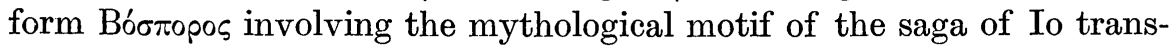
formed into a cow. Several scholars, even most recently, believe in the Thracian ${ }^{101}$ and one in a Phrygian explanation. ${ }^{102}$

In the last two decades considerable progress has been made in the study of the Thracian language, especially by the Bulgarian scholar,

99 A. Fick, Die ehemalige Spracheinheit der Indogermanen Europas. Eine sprachgeschichtliche Untersuchung (Göttingen, 1873), 423 (on Thracian -para in the compounded placenames Bessapara "Bessenfurth," Subzupara and Druzipara, meaning "Furth" with reference to Gr. $\pi$ ópos and MHG var "crossing, passage"). Later on Fick (BB 24 [1899], 295)

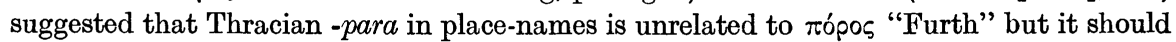

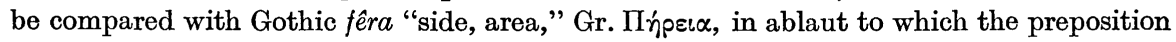
$\pi \propto p \alpha$ stood, and Bessa in Bessapara should have adjectival function. E. Oberhummer, art. Bosporos 1, RE 3 (1899), $741 \mathrm{ff}$. [with earlier bibliography cited]. A.D. Mordtmann (Historische Bilder vom Bosporus [Konstantinopel, 1907], p. 14) concludes from the ter-

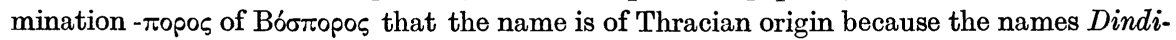
poris, Mukaporis (also on p. 18f.), and Gegaepyris, are Thracian as is Bessipara; the truth, however, is that -poris and -pyris are irrelevant to -para, and also -para and Gr. $\pi$ ópos are equally unrelated.

100 Among 35 fortresses in the Byzantine eparchia of Thrace (Upper Hebros valley), erected by Justinian I, there are listed for the sixth cent. A.D. by Procopius, De aedific.,

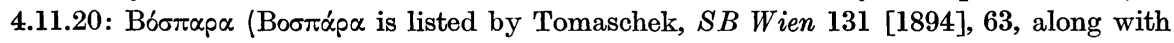

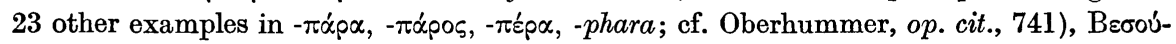

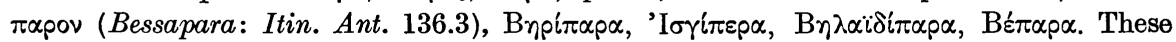
names include as second component - para, also - $\pi \alpha \rho o v,-\pi \varepsilon p \alpha$. It is highly improbable that -para in these denoted "ford" and researchers have not agreed on the semantic side of the word para: "trail, gathering place or assembly point, market place, źuлópıov" or "section, clan" (Tomaschek, SB Wien 130,2 [1894] 16); "ford" like Greek rópos "way, passage through" (N. Jokl, RLV 13 [1929], 285b, 289a; against Tomaschek's semantic suggestions V. Burr, Nostrum mare [1932], 27).

101 For the foreign origin of the name Bórtopos is also V. Burr, op. cit., 26-28, considering it a Thracian (though with a question mark) designation which was Hellenized into Bóoropos but admitting the meaning of $\beta \circ \sigma-$ to be unknown, so that a precise rendering of the name is "today not yet possible" (p. 27). GEL (1925-40), s. Bóoropos, states that the name was "wrongly explained by the Greeks as $O x$-ford, name of several straits"; O. Becker, Das Bild des Weges (1937), p. 26 note 13 [he follows Oberhummer and adds that the Thracian term -para (-paros) frequent in place-names, is equated with Gr. $\pi$ ópos with reference to Walde-Pokorny, 2.39]; V. J. Parry, art. Boghaz-iči, EIsl 1 (1960), 125la [with reference to Oberhummer, $R E$ s. Bosporos]; Ernst Meyer, art. Bosporos (Bóблo@os) 1, Der Kleine Pauly 1 (1964), 933f. [probably routinely following Oberhummer, as the preceding writers]. $\quad 102$ See V. Georgiev, below. 
D. Dečev, to whose credit are two important works, but also by a number of other scholars. ${ }^{103}$ Their work has also been beneficial to our problem at hand.

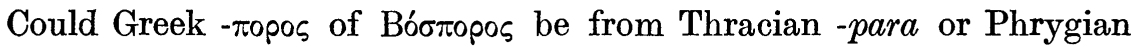
*-poros? Our answer is this: the IE phoneme $o$ yielded Thracian $a$, also IE $p$ changed into either $p$ - or $p h$-, therefore phonologically IE *poros changed into Greek rópos and could have changed into Thracian *para (variants: -para and $-\pi \alpha \rho \alpha$, -phara, $-\pi \varepsilon p \alpha) .{ }^{104}$ The realia, however, are the insurmountable obstacle to this explanation: the sense "ford" attached to Thracian -para would be suitable, in case it were about a major and deep river which can be crossed at definite points only. The meaning of para as Greek żutópıov "market place, assembly point" and the like, endorsed by D. Dečev, who therein is following suit with W. Tomaschek, ${ }^{105}$ is unacceptable; such a semantic content for para is unwarranted, as demonstrated by V. Georgiev. ${ }^{106} \mathrm{~A}$ further explanation of para from IE * $g^{w}$ or $\bar{a}$ "mountain" 107 has also been refuted on the ground that the expected Thracian form from IE * $g^{w}$ or $\bar{a}$ would be kara and in fact

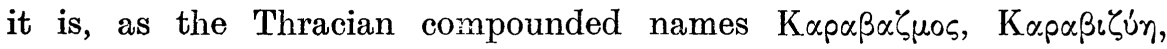
Kapáбoupa show. ${ }^{108}$

${ }^{103}$ D. Detschew [1877-1958], Die thrakischen Sprachreste. Wien, 1957. IX, p. 584. (Österreich. Akad. d. Wiss., phil.-hist. Kl., Schriften der Balkankommission, Lingu. Abt. XIV). [Proper names and glosses, 1-535; addenda, 535-540; Dacian plant names, 541-565; corrections, 583f.] Cf. the reviews by J. Puhvel, Language 33 (1957), 439-446; A. Heubeck, $B N F 9$ (1958), 118-122; G. R. Solta, IF 46 (1961), 65-78. Dečev's work has been praised as an indispensable tool for future studies of the Thracian language, a model collection, and a work to figure as a landmark in the investigation of the ancient Balkan languages. Dečev lists (356f.) 39 Thracian place-names and/or derivatives of such names: Idem, Charakteristik der thrakischen Sprache. Sofia, 1952 (Publications de l'Académie Bulgare des Sciences). A revised second edition appeared in $L B 2$ (1960), Annexe, 145-213. However, it should be said that both works of Dečev contain much that is unacceptable.

N. Jokl, art. Thraker, Eberts RLV 13 (1929), 277-298. The section on the Thracian language $(284-296)$ is quite original (joining this is W. Brandenstein, art. Thrakische Sprache, $R E 11$ [1936], 407-414). Many other studies by various scholars have appeared in the last 20 years; some of them are cited further below.

${ }^{104}$ Dečev, LB 2 (1960), Annexe, 148; Pokorny, IEW (1959), 816f., s. per-, perə-, indicates that Thrac. - $\pi$ ópos, -para occur in place-names. For - $\pi \dot{p} p o s$ he obviously has

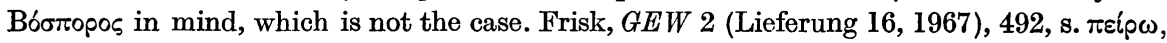

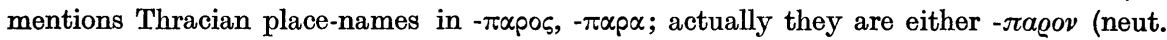
sing.) or $-\pi \alpha \varrho \alpha$ (neut. plur.). See below.

105 Dečev, LB 2 (1960), Annexe, 148.

106 V. Georgiev, "Trakijskata duma PARA etc.," Isvestija na Instituta za bŭlgarski jezik 9 (Sofia, 1962), 3.

107 B. Simeonov, "Noms des lieux thraces récemment découvertes," $L B 6$ (1963), pp. 87-92.

${ }^{108}$ K. Vlahov, "Das thrakische Wort PARA und seine Deutung," Živa Antika (Antiquité Vivante) 15 (1966), p. 297. 
The Phrygian language preserved $o$ unchanged (which Thracian changed into $a){ }^{109}$ This apparently prompted V. Georgiev to advance the interpretation of the name Bóoropos (Herodotus, Aeschylus) as a

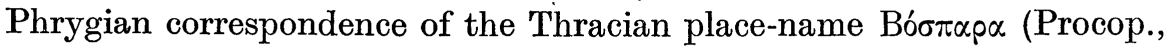
De aedific. 4.11.20), both names supposed to designate "light river, white river." The noun suffix - para is assigned the sense "little stream, rivulet, river" (on the ground that the Hellespont is designated as a river in Hesychius and Stephanus of Byzantium ${ }^{110}$ and bears the second name

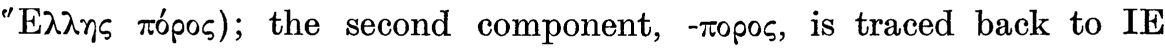
*boro- (with fem. *borā) "river" (Bulg. bara "brook" is compared); the

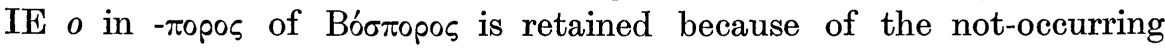
sound-shift (Lautverschiebung), a trait that is characteristic of some Phrygian dialects. ${ }^{111}$ The first component of Bó $\sigma-\pi$ opos is linked with IE *bhos-: Greek $\varphi \tilde{\omega} s$ "light", $\varphi \omega \dot{\sigma x \varepsilon l}$ "it dawns," Skt. bhās- "light, shine,"112

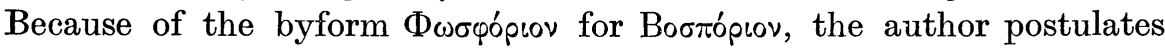
$\Phi \omega \sigma \varphi o^{\prime} \iota_{0}$ as being "eine griechische Teilübersetzung des phrygischen

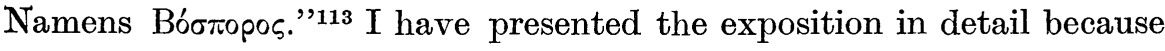
it is ingenious in combining data, but it is at the same time too farfetched and unconvincing both in the phonological and the semantic aspects, explaining ignotum per ignotius. If this complex interpretation is countered with Boòs rópos (IE gwowós póros), the simplicity of the

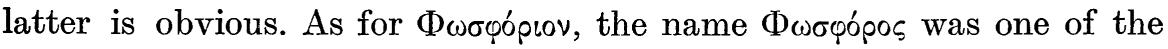
several names of the goddess of light; therefore the folketymological

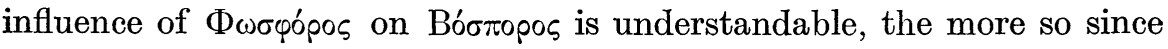

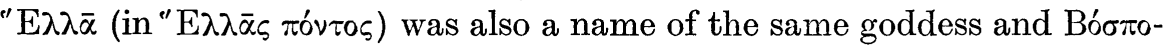
pos was also "Hellespont." ${ }^{114}$ As far as the Byzantine fortress Bó $\sigma \alpha \alpha \alpha$

109 Cf. F. Solmsen, "Zum Phrygischen," $K Z 34$ (1897), 49, and P. Kretschmer, Einleitung in die Geschichte der griechischen Sprache (1896), p. 221.

110 This statement is made by A. Chatzis, $E E \Phi \Sigma$ of the Univ. of Athens 1 (1935, publ. 1937), 140 and again by V. Georgiev, $L B 3,2$ (1961), 26 note 1. In fact, however, neither Hesychius nor Stephanus of Byzantium calls the Hellespont a river. In the new ed. of

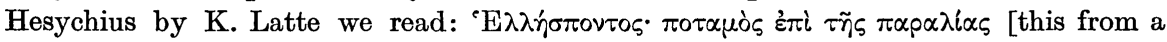

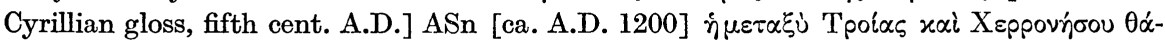

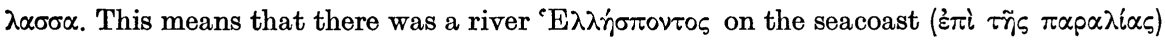

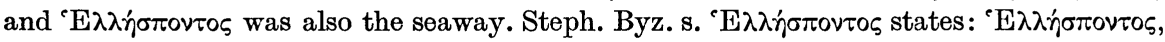

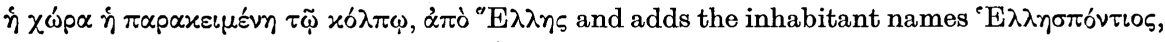



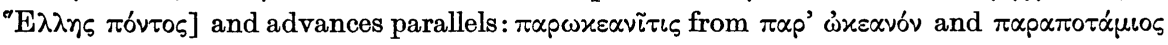
from $\pi \alpha \rho \dot{\alpha} \pi \circ \tau \alpha \mu \tilde{\varphi}$. It is an utter misunderstanding that he calls Hellespont a river.

111 V. Georgiev, "La toponymie ancienne de la Péninsule Balkanique et la thèse mediterranéenne," $L B 3,1$ (1961), p. 9 [the author lists on p. 9 f. 41 examples in -para etc., to which six more are added, though doubtful]; also pp. 25-27; idem, "Trakijskata duma PARA etc.," Isvestija na Instituta za bŭlgarski jezik 9 (1962), pp. 5-10.

112 Georgiev. $L B 3$ (1961), p. 26.

113 Loc. cit.

114 L. Malten, $R h M, N F, 93$ (1949), p. 79. 
in Thrace is concerned, it is obviously recorded too late (sixth cent. A.D.)

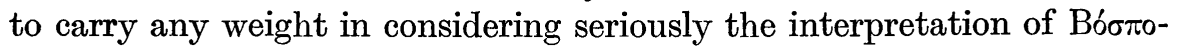
pos, which had existed over a millennium earlier.

Pertinent arguments brought up against this novel attempt by $K$. Vlahov are as follows: (1) the forms with - $\pi \alpha$ pov (i.e., sing. neut. of para) came about much later in time than the form tópos in Greek, e.g., in Hesiod [eighth cent. B.C.], and (2) the forms -para and - $\pi$ apov are attested in names, and this points to the fact that such compounded names

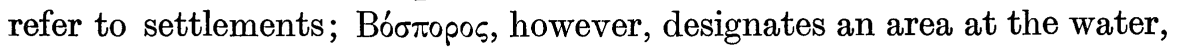
where a ford is fittingly expected; ford carries also the basic meaning of the Greek term mópos. $^{115}$ The sense "river" was rejected with good reasons: among the more than 42 different places named with paracompounded words no rivers are included but all of these places are attested as located in mountainous areas. ${ }^{116}$

Vlahov's discussion, the most recent (1966) that I know, seems to me plausible. The Thracian appellative para is, in fact, a neut. plur. noun; ten instances out of the certain 42 compounds show plural genitive or dative forms, which are the earliest recorded ones. The Thracian term para, corresponding to Dacian dava "settlement," signifies something similar: originally meaning "fences, palisades," then "farms fenced-in with palisades," "farms," and then "group of farms, village, settlement"; Dacian dava and Thracian para are, therefore, synonyms. The etymology for para offered by Vlahov is from IE *por- $a$ (basic radical *sper- "spar, rafter; stake"), whence Old Bulg. -pora "fulcrum, baculum."117 A sing. neut. form - $\pi \alpha$ pov is found in compounds such as Bpi $\pi \alpha p o v$ ( $\beta p l-$ of

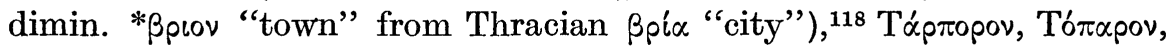
etc. The $-\pi \varepsilon \rho \alpha$ form, attested in late literary sources, is explained as the

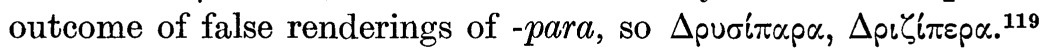

Mr. Vlahov's laudable exposition has solved the crux of para. His conclusions entail also the demolition of the Thracian origin of the name Bóoropos, which, in his own words, "eher griechischer Herkunft ist und

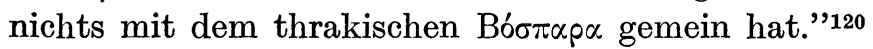

115 So Vlahov, "Das thrakische Wort PARA und seine Deutung," Živa Antika (Antiquité Vivante) 15 (1966), 304. It should be noted that Bóonopos is attested in Herodotus but not in Hesiod, as both Georgiev ( $L B$ 3.26) and Vlahov (loc. cit.) inadvertently let their readers believe. The term $\pi 6$ pos occurs in Hesiod.

116 K. Vlahov, op. cit., p. 297.

117 With regard to Old Church Slavic -pora see IE 1. (s)per- in Pokorny, IEW $990 \mathrm{f}$. (with references to A. Walde - J. Pokorny, Vergleichendes Wörterbuch der indogermanischen Sprachen [Berlin, 1928-32], 2.665f. and others). Pokorny (IEW 816) holds both $-\pi \alpha p \alpha$

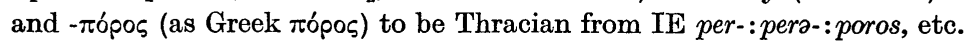

118 Since the original meaning of Thraco-Phrygian $\beta p i \alpha$ (from IE *wriyā: *wer-) was "stronghold, citadel," Bpítapov would have signified "fortified city" or "city citadel." Cf. Pokorny, $I E W$ (1959), 1152; s. 2. uer. $B$ "high."

119 Vlahov, op. cit., pp. 298-303; summary, p. 304.

120 Ibid., p. $303 f$. 


\section{b. GREEK}

The Greek etymology of Bóoropos has come down to us from antiquity. ${ }^{121}$ Its discrediting, however, by scholars was based on the conviction that a Thracian (or Phrygian) etymon had been proved, so that Eugen Oberhummer felt confident enough to state that the derivation

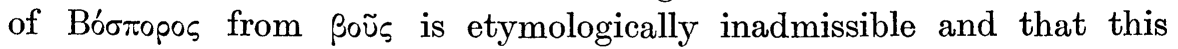
"derivation of $\beta o \sigma-$ was perhaps made a mess by the original Greek

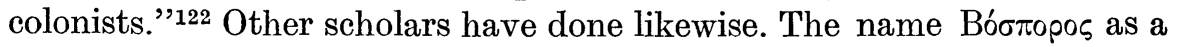

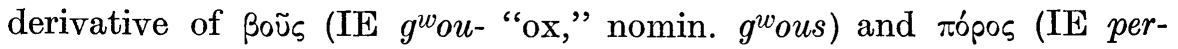
etc.) is not honored by Walde and Pokorny; instead Thracian - $\pi$ ópos,

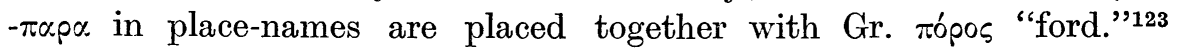
Likewise the Greek etymon is rejected by V. Georgiev as being an old folk etymology untenable both on the semantic and the phonological counts. ${ }^{124}$

Here the case and the arguments in its favor will be presented, a solution about the first component of Bóoropos suggested, and pertinent details discussed.

The ancients were aware of a connection (correct or not) between Bóoropos and Boòs rópos. A late name form Boòs rópos for the Thracian Bosporos occurs in a dactylic hexameter in Oppian (second / third cent. A.D.) and for the Cimmerian Bosporos in the Orphic Argonautica (prob-

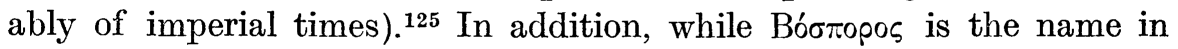

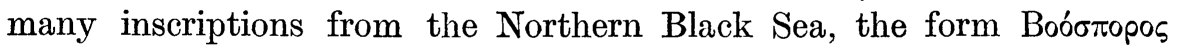
quadrisyllabic is used in four inscriptions from the same area. ${ }^{126}$ As for

121 Cf. the etymology in Roman authors from Varro [first cent. B.C.] to ca. A.D. 400: Varro [ca. 37 B.C.], Res rusticae 2.1.8, ed. Goetz (Teubner, 1929); Pliny [A.D. 23-70], NH 6.2, ed. Schuster (Teubner, 1952 (and Solinus [after A.D. 200] 23.16); C. Valerius Flaccus [died A.D. 92], Argonautica, 4.419, ed. Kramer (Teubner, 1913); Ammianus Marcellinus [ca. A.D. 390], Res gestae, 22.8.13, ed. Gardthausen (1874ff.); Hieronymus, Chron. ad annum Abrahae [ca. A.D. 380] 161, ed. Schöne, Eusebii chronica 2 (1866); Scholia in Horatium [a late compilation] in carmina 2.13.15, ed. Keller 1 (1902): quasi bo $\langle 0\rangle$ s phoros; Avienus [middle of fourth cent.], orbis terrae, 199, ed. Holder (1887).

122 Oberhummer, art. Bosporos 1, RE 3 (1899), 741 ["etymologisch unerläßlich"].

123 A. Walde und J. Pokorny, Vergleichendes Wörterbuch der indogermanischen Sprachen 1 (1930), 696f.; 2 (1927), 39. The authors also mention (2.39) Fick (BB 24.295), who treats

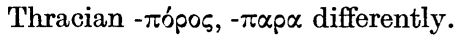

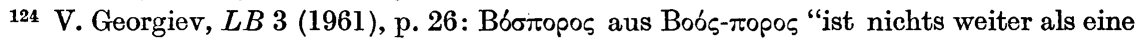
alte Volksetymologie. Semantisch und lautlich ist sie unhaltbar."

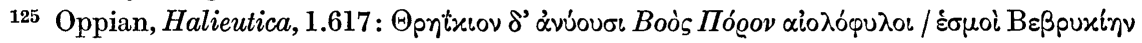
$\tau \varepsilon x \lambda \pi$. (And swarms of various tribes make the Thracian Ford of the Ox, past the Bebrycian Sea [i.e., the Propontis = the Sea of Marmara] etc.); Orphic Argonautica,

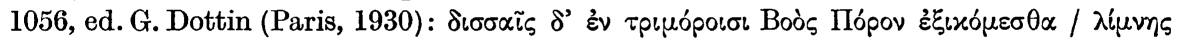

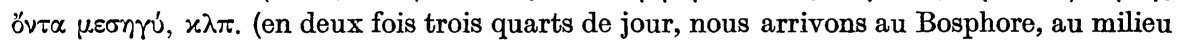
d'un etang, etc.).

126 B. Latychev, Inscriptiones regni Bosporani Graecae et Latinae (Petropoli 1890) (= Inscr. Antiquae Orae Septentrionalis Ponti Euxini Graecae et Latinae, vol. 2), No. 355,

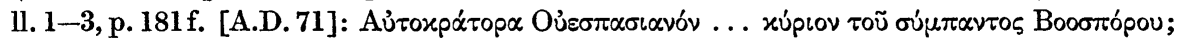


the form Boòs Mópov in Oppian and the Argonautica, this de-compounding, as it were, of the name Bóøлороs was dictated to the author prob-

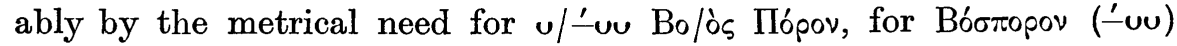
would not do for the hexameter. The form Boórлopos in inscriptions, on the other hand, shows, I submit, an influence of the learned tendencies of bureaucratese.

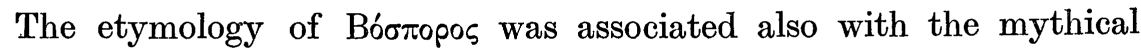
motif about Io who, transformed into a cow, is supposed to have swum across the strait near Byzantion. ${ }^{127}$ However, when concrete names like

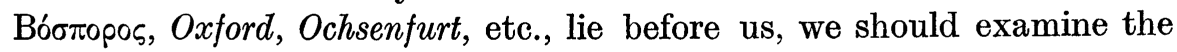
language first and then the myths.

\section{Bosporos "Hellespont"}

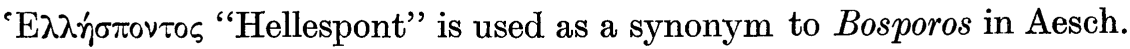

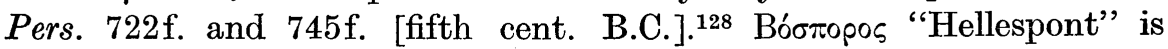
clearly documented in the ancient commentators: the scholion on Aesch.

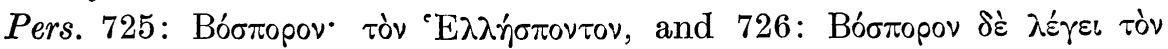

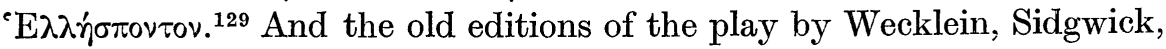
Mondry-Baudouin, and Mazon ${ }^{130}$ have adopted this interpretation.

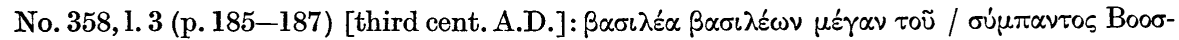

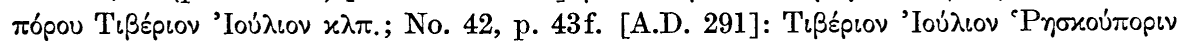

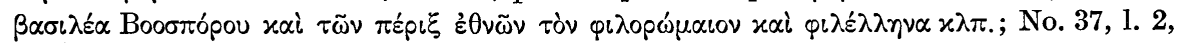

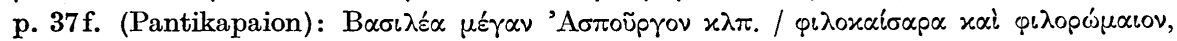

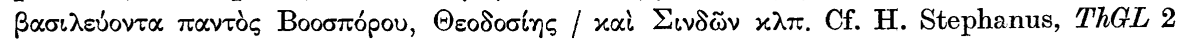
(1833), 336, s. Bóбтороs.

${ }_{127}$ Polyb. 4.43.6; etc. Cf. Walbank, op. cit., 1.497. Other attestations in Oberhummer, op. cit., 741 f.; Pape-Benseler 1.220f. Cf. V. Burr, Nostrum mare (1932), 26.

Another version of the Io myth is given by the Schol. Apoll. Rhod. 2.168a. This saga is very old as an important part of the mythology of the Argives, who Hesychius of Miletus [sixth cent. A.D.] asserts were the first colonists of Byzantion; Hesychius of Miletus, 3 FHG 4.147.

Another version is that at the time of the incursion of the Phrygians an ox swam across the strait at Byzantium and thus led the Phrygians across the ford (Eusthathius ad Dionys. Perieg. 140; Arrian, fr. 35; $F H G$ 3.593). This precise localization enhances the assumption that the name Bóoropos would have been set near Byzantium; Steph. Byz.

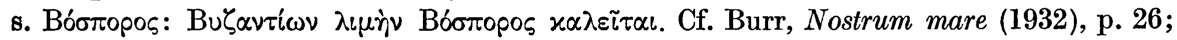
above, note 40 .

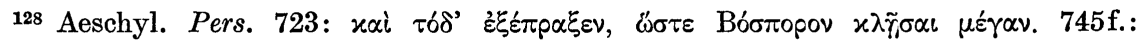

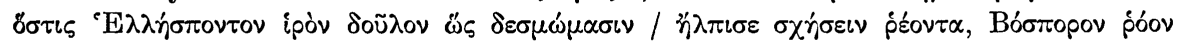

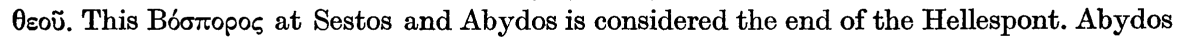
was on the Asian side in Mysia (south of modern Nagara Point) and Sestos was located on a plateau 350 feet from the Hellespontine shore of the Thracian Chersonese at the narrowest point of the straits (the Sestos site now being occupied by a Turkish monastery); cf. Walbank, op. cit., 2.539 [on Polyb. 16.29.3].

129 Scholia ad Aesch. Pers., ed. Dähnhardt (1894), 1. 725 (scholia of the Mediceus), 1. 726 (scholia Byzantina).

130 Cf. Th. Reinach, REG 36 (1923), p. 349 (letter to the editor dated 21 Jan. 1924). 
For the geographer Phileas of Athens [also of the fifth cent. B.C.] there were in the area of Byzantion two Bóoropor, as we learn from the Souda. ${ }^{131}$

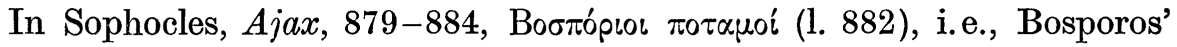
rivers, end in Bosporos $=$ Hellespont. ${ }^{132}$ Finally, the historian Hesychius

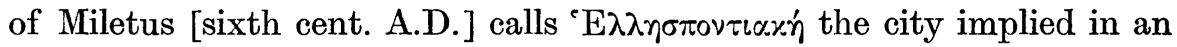

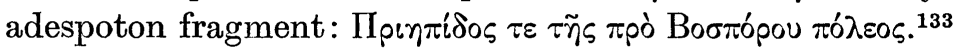

E. Oberhummer considered the extension of the Bóбropos to the Hellespont arbitrary on Aeschylus' part, ${ }^{134}$ while Th. Reinach criticized Oberhummer's judgment as unjustified on the basis of the facts $;^{135}$ he also observed that Pape-Benseler and Bailly erroneously interpreted Aeschylus, Pers. 723, as the strait of Constantinople. ${ }^{136}$ But it was A. Ronconi who argued, in my opinion, successfully against Oberhummer. ${ }^{137}$

No more needs to be said about the matter since the application of the

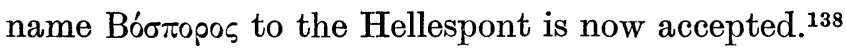

Here the onomastic aspects of the matter also come to the fore. One well known principle in place naming is the expansion of the area that was originally represented by the name. In our case, it seems to me that

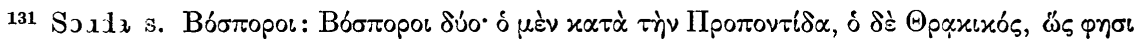
$\Phi \iota \lambda \varepsilon_{\alpha} \alpha \varsigma$ (ed Thomas Gaisford, Oxford, 1834; ed Gaisford-Bernhardy, 1853). - A. Ronconi, "Il Bosforo" in his article "Per l'onomastica antica di mari," SIFC 9 (1931), $221 \mathrm{f}$. Ronconi treats the matters of Hellespont and Propontis in a separate chapter, "Ellesponto e Propontide," ibid., 225-242. - Phileas' testimony, which had been disregarded by Reinach and Cahen, eliminates in Ronconi's opinion every doubt about the existence of a geographic term

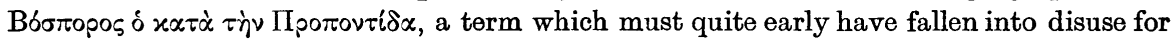
obvious reasons: the name 'E $\mathrm{E} \lambda \lambda \eta^{\prime} \sigma \pi \circ \tau_{\tau} \mathrm{s}$, an earlier one and more convenient, easily pre-

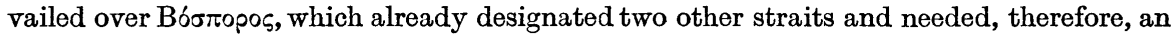

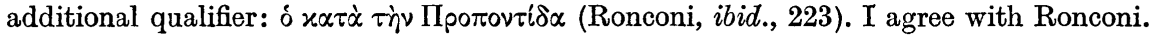

132 Cf. on this viow commentaries and criticisms in Cahen, Revue des études anciennes 27 (1914), p. $179 \mathrm{f}$.

133 E. Diehl, Anthologia lyrica Graeca, fasc. 3: Iamborum scriptores ${ }^{3}$ (Leipzig, 1952),

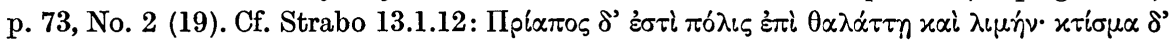

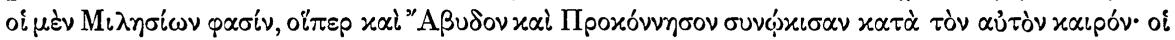

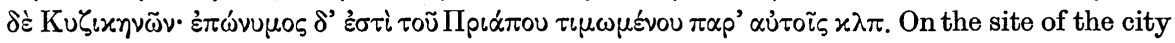
of Priapus see Walter Leaf, Strabo on the Troad (Cambridge, 1923), p. 73. Hesychius of

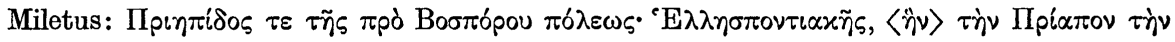

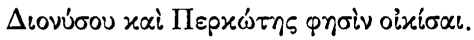

134 Oberhummer, $R E \mathbf{3 . 7 4 2 .}$

135 Th. Reinach, "Le Bosphore chez Eschyle," REG 36 (1923), 64. The author mentions Henri Weil's comment on Aeschylus, Pers. 723: Bospori nomen ad Hellespontum etiam v. 731 transfertur (1867) (Reinach, p. 63), and Alexis Pierron in his translation of Aeschylus (eighth ed., 1869); Pierron says, "Aeschylus gives poetically the name of the Bosporos to the strait of Helle, as he could have given it to any other strait," and voices his surprise about the fact that the new editors of the Thesaurus did not pick up this remarkable peculiarity (Reinach, p. 63).

136 Pape-Benseler, 220 s.v.; Bailly, Dictionnaire grec-français, s. Bóotopos.

137 See above, note 102.

138 Thus, $G E L$, s. B6блtopos, p. 323 a. 
the name Bóoropos of the area of Byzantion could in time be extended from the general meaning "narrows" of Byzantion to the lower part toward the Aegean and, since the Hellespont presented the same qualifications as, and was the continuation of, the upper part toward the Black Sea, so also the Hellespont was named Bóctopos. In fact, the qualification consisted of being the narrow straits extending from the Black Sea to the Aegean, and this is again reflected in the Byzantine name $\Sigma \tau \varepsilon v o ́ v: ~ \tau \dot{\alpha} \Sigma \tau \varepsilon v \dot{\alpha}$ (and $\tau \dot{\alpha}$ K $\mathrm{\alpha} \alpha \omega \Sigma \tau \tau \varepsilon v \alpha$ ) were the straits of the Hellespont

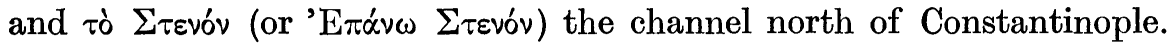

It is fitting to dicuss in this respect the possibility of a common noun

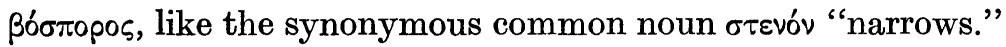

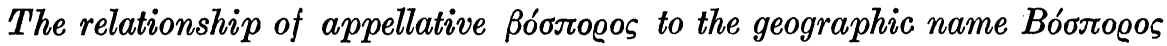

The name Bóoropos could originally have been a common noun. As

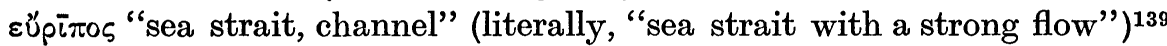
had a place-name already in Mycenaean Greek, written Ewiripo ( $A n$ 610.6; with ethnic Eủpíiıs, written Ewripia $A a$ 60), so a narrow water-

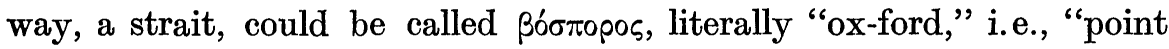
of crossing (the waterway),"140 therefore a synonym of anc. Boúrop $\theta \mu \circ$ (now Mou $\zeta^{\alpha} \times(x)$, name for a cape near Hermione at the strait facing the islet of Aperopia (mod. $\Delta$ oxós), and another in the Sporades. The only

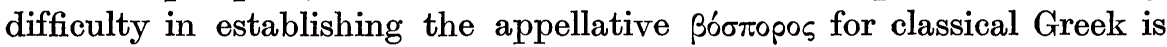

139 Cf. also "£ عúpırtos euripus": Hermeneumata Einsidlensia [cod. of 1503], CGL 3 (1892), 246, l. 1 .

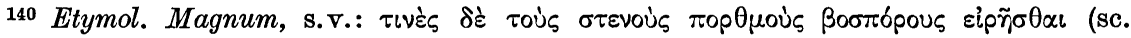

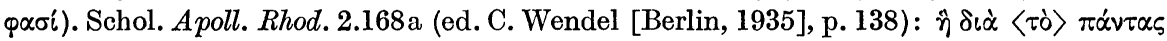

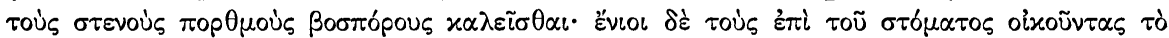

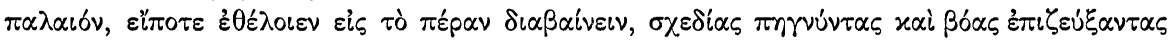

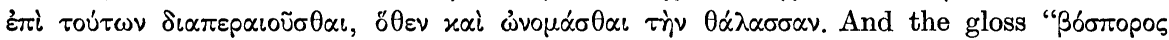
bosphorus," CGL 3 (1892), 246, 1. 2; Thesaurus glossarum emendatarum, ed. G. Goetz,

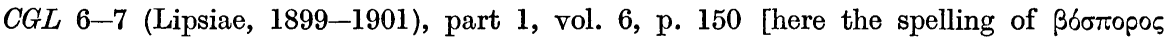
with lower case $\beta$ - means nothing since the codex lists other geographic names, all with

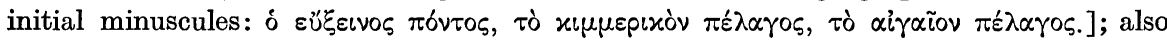
bosforos (4.26.11), bustyrum transitus maris (5.543.19), bosphorus transitus ponti in Asia (4.212.28; 586.18); transitus maris in Asia, stella uespertina (4.594.5; 489.22 [in Africa]); transitus maris uel stella (4.595.12); stella matutina, Lucifer uel transitus maris in Asia (4.602.1); these were reproduced in ThLL s. Bosporus, 2 (1900-06), 2143, 1. $74 \mathrm{f}$. , and A. Forcellini, Lexicon totius Latinitatis, V. Onomasticon (Patavii, 1940), s. Bosporus, p. 277. The noun seems to have been adopted in Latin as bosporus "fretum," as seen in Horace, carm. 2.13.14: navita Bosporum / Poenus perhorrescit. "Bosporum pro quolibet freto dixit," i.e. he said bosporus in place of any "fretum"; cf. Th. Reinach, "Le Bosphore chez Eschyle," REG 36 (1923), 350. The appellative has been also in French in the form bosphore; cf. E. Littré, Dictionnaire de la langue française 2 (1885-86), s. Bosphore: “... par extension tout détroit de peu d'étendue"; employed in this sense often by the author Elisée Reclus (cf. Reinach, loc. cit.). 
that, beside the late, medieval, testimonies for it, i.e., in the Etymologicum Magnum, in the scholiast to Apollonius Rhodius, and the dubious glosses, no classical literary or epigraphic ones are available, none of the fifth cent. B.C., ${ }^{141}$ for which the term is claimed. However, the old edition of Aeschylus, Pers. 723, by Schiller and revised by Conradt accepts

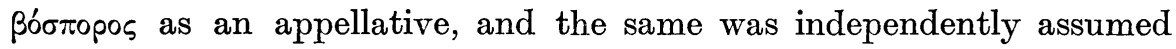

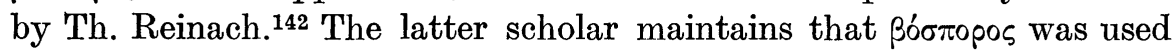

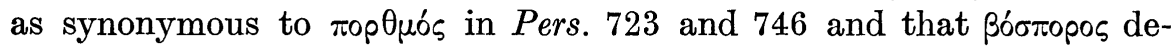
signates a "very narrow strait" (or passage, crossing) and so he trans-

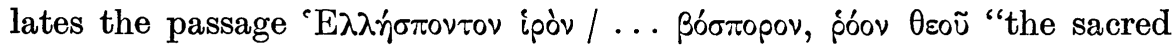
Hellespont, the narrowed strait, where a god flows" (i.e., the anonymous aquatic god); and it is for this that he draws support from the Etymol. Magnum.

Conversely, Ronconi understands this as an opinion, expressed in the Etymol. Magnum but not generally shared, and suggests an ancient etymologist conceived ßóoropos as "a strait across which an ox can swim."143 Ronconi's conclusion is that this testimony carries not too much authority. As Cahen had observed much earlier, this testimony alone can prove

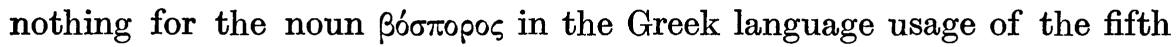
cent. B. C. since no other instances of the noun have been transmitted. ${ }^{144}$

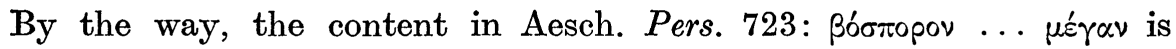
hardly a contradiction in terms, as Ronconi (ibid., 223) thinks; for here

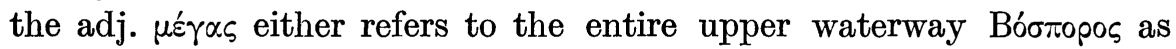
against the Bóoropos = Hellespont or means "important, significant," as it really was.

Since we can hardly dismiss $\beta$ óoropos recorded as an appellative noun in the Etymol. Magnum and mentioned by the scholiast to Apollonius Rhodius as carrying no weight, V. Burr ${ }^{145}$ and P. Kretschmer ${ }^{146}$ accepted the noun as a fact. In favor of this view I may recall the fact that many words of the ancient languages have not been preserved in the texts for us because they either were not used in writings or the texts in which they were employed were accidentally lost to us forever; yet the Etymol. Magnum (whose lexica-sources go back to the ninth cent. A.D.) and the scholiast may have had more texts containing this particular word than

141 Ronconi, SIFC 9 (1931), 220-225; on p. 222 he considers the statement in Etymol. Magnum to be an opinion of an ancient etymologist with no validity for us; he also dismisses the comment to Horace, carm., 2.13.14 (Navita Bosporum Poenus perhorrescit): Bosporum pro quolibet freto dixit. But Ronconi is unaware of the scholion to Apoll. Rhod. 2.168 a and the gloss in the Thes. glossarum emendatarum (see preceding note).

142 Th. Reinach, $R E G 36$ (1923), p. 349 (per letter to the editor of $R E G$, dated 21 Jan. 1924). $\quad 143$ Ibid., p. 64.

144 Cahen, REG 27 (1914), p. 178; Ronconi, SIFC 9 (1931), p. 223.

145 V. Burr, Nostrum mare (1932), p. 26 with note 47.

146 P. Kretschmer, Glotta 27 (1939), p. 29. 
we now have at our disposal; or because the term, after becoming a name, fell into disuse. ${ }^{147}$

When three or more instances of the name Bóoropos for "straits" in the NE Mediterranean area came into being and needed to be more

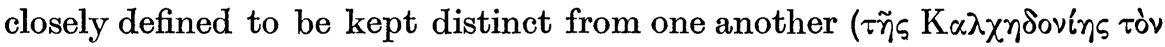

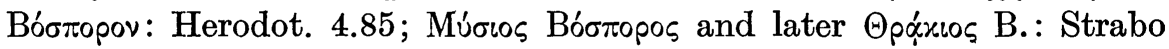

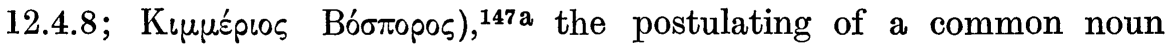
underlying them all was worth exploring. On the other hand, placenames do also become appellative nouns. Lacking ancient literary and inscriptional testimonies, it would seem that we are forced to assume that the latter is the case about Bóøtopos. The solution is, of course, also closely related to the etymology of the name; a non-Greek etymology for it would exclude the preexistence of a Greek appellative. The Greek etymology again must draw on comparison with the terms "ford" and "ox-ford" in other languages.

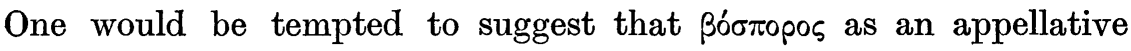
could have two connotations, (1) ford, strait, and (2) large strait. ${ }^{148}$ The latter of these could evolve secondarily on the basis of compounds

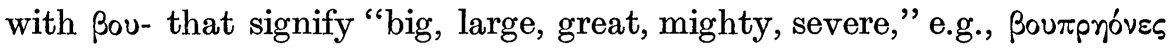

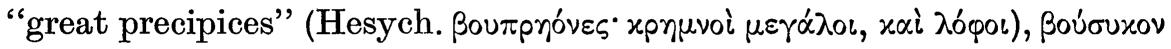

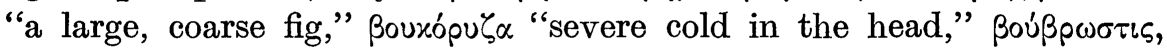

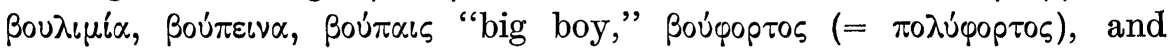

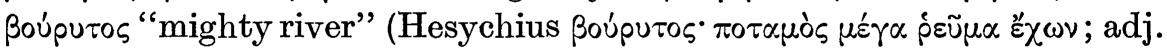

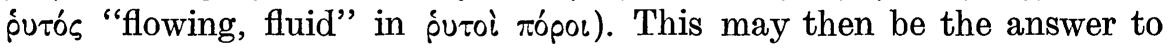

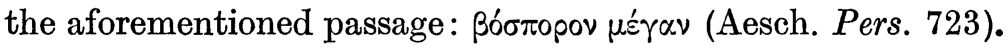

\section{$-\Pi O P O \Sigma$}

The second member of the compound Bóoropos, held to be of Greek origin, presents hardly any difficulty in interpreting it within Greek. The noun $\pi$ ópos m. "ford" occurs in Homer for rivers (Iliad; Aeschylus, Hero-

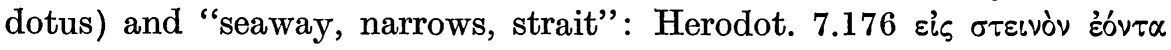

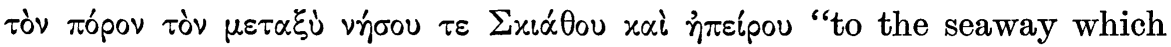
is narrow between the island of S. and the continent" (Hesiod [eighth

147 The premise that in classical times and in the colonization period places were named

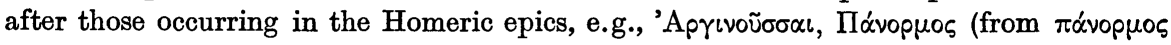

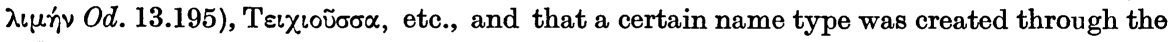
influence of the Homeric language (see E. Risch, "Ein Gang durch die Geschichte der griechischen Ortsnamen," Museum Helveticum 22 [1965], 196-199) is, in my opinion, erroneous. The epic poets utilized names that were used by the Greek-speaking people.

147 a The Strait of Messina between Sicily and the Italian continent is called the Bosporus of Italy.

148 This was indicated by A. Fick, $B B 22$ (1896), 11: B6oropos "large or main ford." 
cent. B.C.], Aeschylus, Pindar, Aristophanes); ${ }^{149}$ thus, Hesiod Theog.

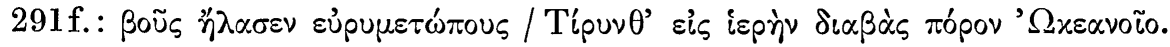
A place near Selybria was called Mópos (Diod. Sic. 14.12) and so was an Attic demos; a torrent Pòro in the area of Zungri (province of Catanzaro) in South Italy is from Gr. $\pi$ ró $^{150}$; in fact, Пópos "passage" is really a common toponym in Greece. ${ }^{151}$ In Modern Greek, Mópos

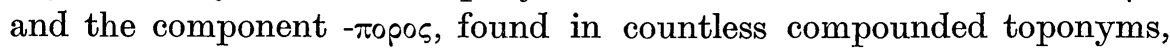
designate river crossings; I need not parade examples here. Furthermore, we have the compounds eujpútopos "with broad ways" (about the sea)

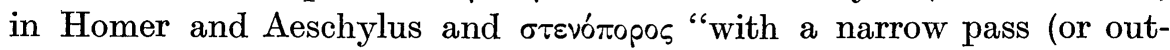
let)" (with 'ं $x \tau \dot{n}$, öpros, etc.) in Aeschylus, Euripides, etc., and noun

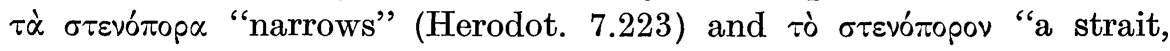
narrow" (Herodot. 7.211). From adjectives there have derived toponyms such as 'E $\mathrm{E} \tau \dot{\alpha} \pi$ ' opos for a river in the Troas (Il. 12.20; Hesiod, Theog. 341;

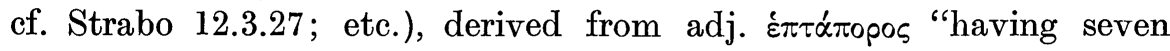
crossing-points" (this used for the Nile meant "seven-mouthed"), По ú $^{-}$

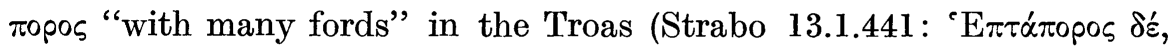

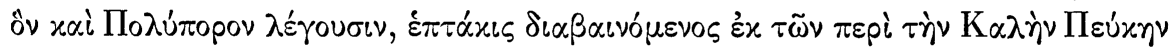

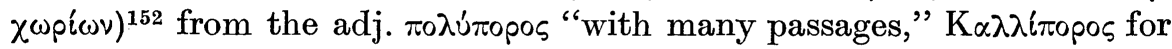
a river in South Italy (thirteenth cent. A.D.), ${ }^{153}$ today Galliparo. I do

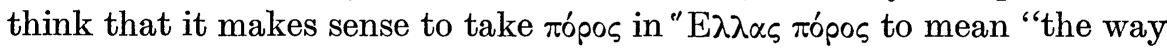
from sea to sea, the seaway" or "a passing-through (for the sailing ship)."154

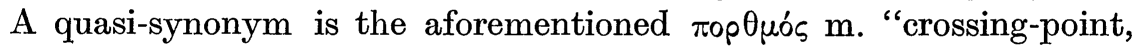
place crossable by a ferry; narrow sea, strait" and a compound with it

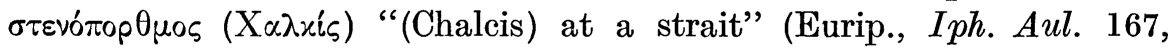

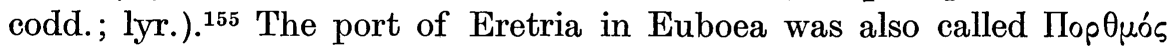

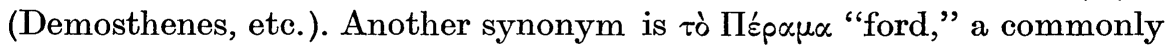
used toponym in Greek territory.

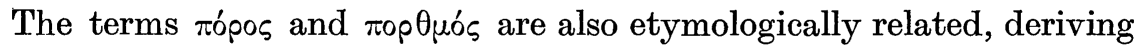
from the stem $\pi \circ \rho-\left(\pi \varepsilon \rho-\right.$ in the verb $\pi \varepsilon i \rho \omega$ "pierce, run through": $\pi \circ \rho^{-:}$

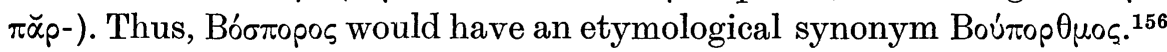

149 On the word $\pi$ ópos see O. Becker, Das Bild des Weges (1937), pp. 25-29.

150 G. Rohlfs, $B N F, N F, 4$ (1969), p. 129.

151 So, e.g., the name П'́pos for an island (anc. $K \alpha \lambda \alpha u ́ p \varepsilon\llcorner\alpha)$ is probably also very old (E. Curtius, Peloponnesos 2.447); П'́pos is a deep gorge in the coastal mountain range in Kephallenia.

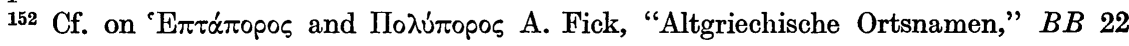
(1897), pp. 61 and 63.

${ }_{153}$ That river emptying into the Tonian Sea is attested in F. Trinchera, Syllabus graecarum membranarum (Napoli, 1865), p. 381; cf. Rohlfs, op. cit., p. 121.

154 O. Becker, Das Bild des Weges (1937), p. $28 \mathrm{f}$.

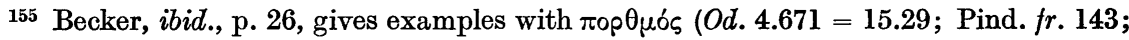
etc.).

156 See above. The adj. ßoutrópos "ox-piercing" (Herodotus, Euripides, Xenophon)

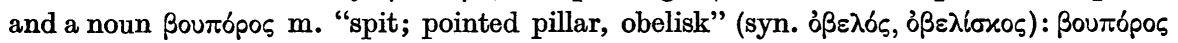


The explanation of "E $\lambda \lambda \bar{\alpha} \varsigma$ rópos as "Helle's seaway" is very appealing, wherein the name "E $\mathrm{\lambda} \lambda \bar{\alpha}$ was the name of a geographic feature in

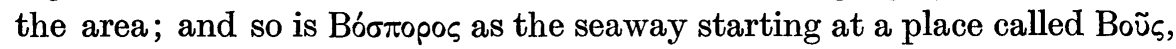
so Boòs rópos.

\section{$\mathrm{BO} \Sigma-$}

The crux of the problem rests mainly in the first member of the compound Bóoropos and attempts have been made to explain the syllable

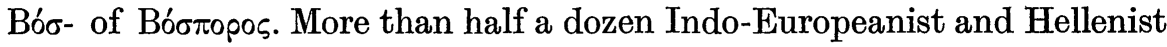
scholars have so far adopted the Greek origin of the name (though a few

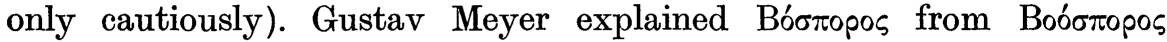
by hyphaeresis, as did Hatzidakis, Schwyzer, and Kretschmer (who earlier had thought of Thracian origin), and, following the latter, Frisk and Chantraine. While Schwyzer cautiously remarks that Bóoropos may have been the outcome of folk etymology, yet he explains the form from *B[0]ó $\sigma-\pi 0 p o s$, i.e., with loss of the unstressed first vowel. ${ }^{157}$. Hyphaeresis had been assumed earlier by G. Meyer and Hatzidakis. ${ }^{158}$ Kretschmer, more convinced of the Greek etymon and based on hyphaeresis explains

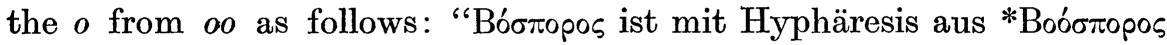

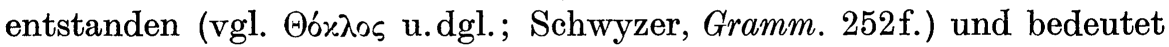
in der Tat 'Rinderfurt', mythologisch auf die Io-Kuh bezogen"; he further mentions the existence of mythological place-names and lists a few, in disagreement with V. Burr's assertion to the contrary. ${ }^{159}$

Hyphaeresis ${ }^{160}$ is the expulsion of a syllabic vowel or, in other cases, of a non-syllabic one; ${ }^{161}$ again another hyphaeresis includes several

'Apotvóns (of Mt. Athos, Callimachus, Aitia 4, fr. 45, ed. R. Pfeiffer; cf. GEL, A Supplement [1968],32) contain the active verbal adjective for "piercing."

157 E. Schwyzer, Griechische Grammatik, 1 (1939), p. 577 note 8.

158 G. Meyer, Griechische Grammatik ${ }^{3}$ (Leipzig, 1896), p. 224 (§152). G. Hatzidakis,

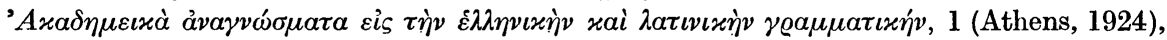

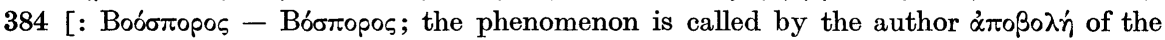
vowel].

159 P. Kretschmer, Glotta 27 (1939), p. 29 [apropos of reviewing V. Burr's Nostrum

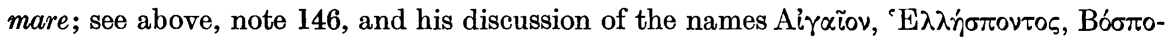
pos]; accepted by both authors of the recent Greek etymological dictionaries: Frisk, GEW 1 (1954-60), p. 254, and Chantraine, Dict. etym. 1 (1968), 187 a [both with reference to Kretschmer]; cf. also J. B. Hofmann, Etymologisches Wörterbuch des Griechischen (Munich, 1949), p. 37. So also K. Vlahov, Živa Antika 15 (1965), p. 303.

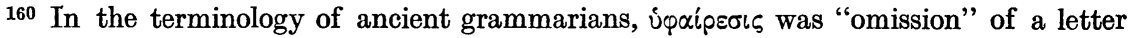
(Scholia graeca ad Aristoph. Aves 149, ed. F. Dübner [Paris, 1877; Hildsheim, 1969]; Etym. magnum 389.6), while ourrotin was "cutting a word short by striking out one or more letters, or shortening involving loss of a syllable" (Herodiani technici reliquiae, 2.247, ed. A. Lentz [Leipzig, 1868]).

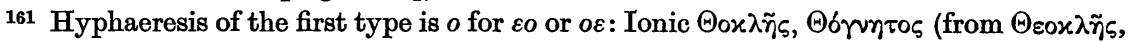

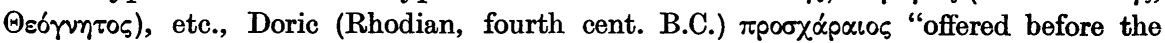




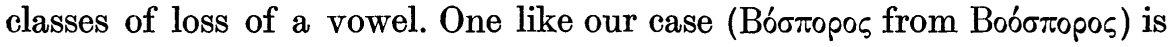
called $\sigma u \gamma$ хо $\eta_{\eta}$, a general term describing visually what happened to words at different times and by varying causes, without classification. ${ }^{162}$

If we wish to search deeper for the ultimate cause of this phenomenon and not be content with the appearances of the written word, a fresh approach to the clarification of this matter may be attempted. First, let us survey the compounds with ßoũs.

I. Bou- is the first member of compounds, at least partly contracted from $\beta_{00-}$, in more than one hundred examples, the earliest being in

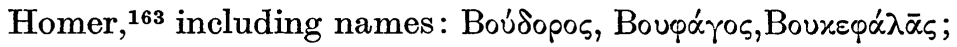

II. Boo-compounds with no change in the vowels, so $\beta 00 x \lambda \varepsilon \psi$ (Sophocles),

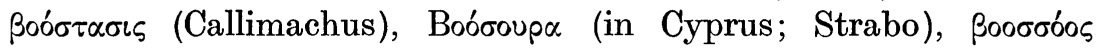
(Nonnos);

\section{III. $\beta 0$ - in appearance from $\beta 00-$.}

The first two sets of examples are well understandable but the third is problematic. The third category is supposed to reflect the phenomenon called "hyphaeresis"; the few examples render the phenomenon a "sporadic" one in view of the instances in category II and show "surreptitious" loss of a vowel to be an invented artificial device in place of the yet to be found real explanation.

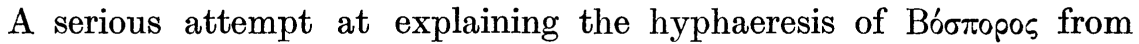

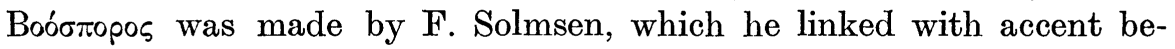
havior in Greek. It is unfortunate that his views did not appear in a full exposition and we have only a brief report given us by A. Thumb. ${ }^{164}$ According to Solmsen, Greek accent is supposed to have had in early

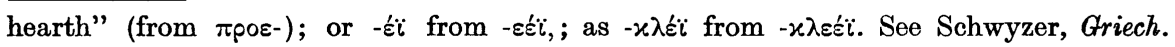
Grammatik, $1.253 ; 580^{2}, 3 ; 398^{5}$.

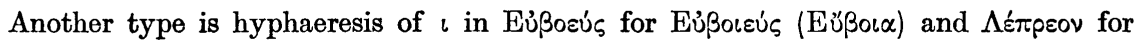

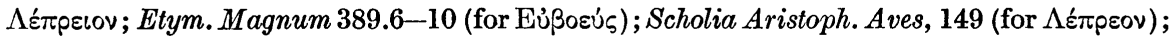
see note 128.

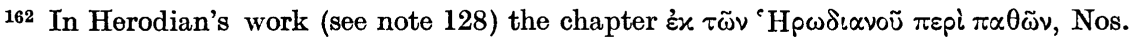

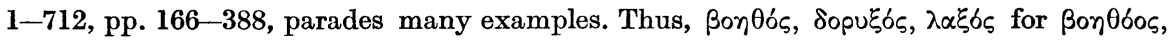

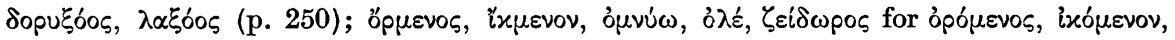

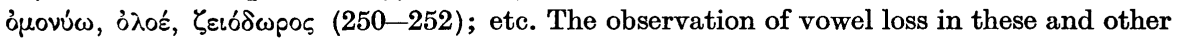
paraded instances is visual, superficial, and often against the true derivation of the words,

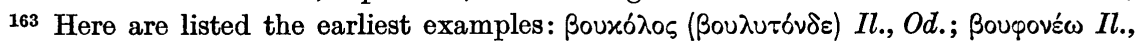

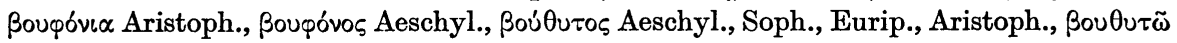

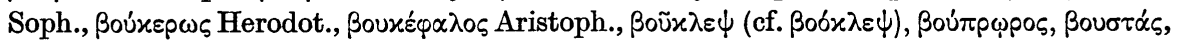

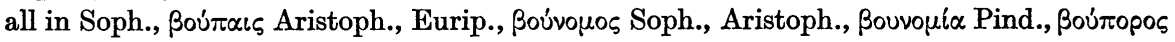

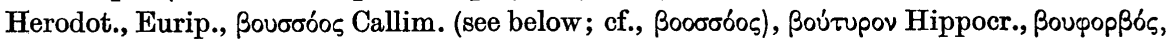

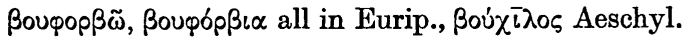

164 F. Solmsen, "Zur Frage nach dem Wesen des griechischen Akzents," in the report of A. Thumb, "Die indogermanische Sektion auf der Kölner Philologenversammlung, 25.-29. Sept. 1895," IF 6 (1896), Anzeiger, p. 154. 
times the musical element plus an expiratory moment, and certain cases of hyphaeresis of $o$ present the phonological phenomenon whereby the loss of this vowel is caused by the shift of the accent in the word. In our case, the author suggests, the inflection went as follows: nomin. sing.

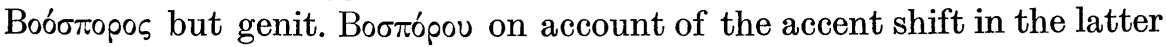

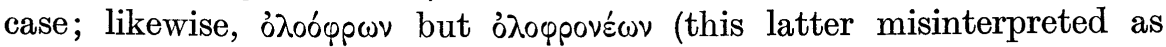

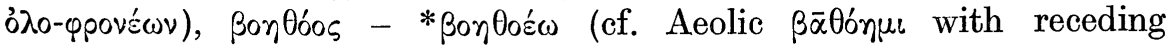

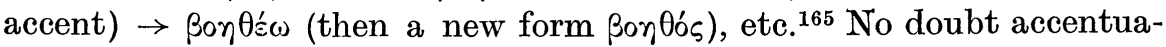
tion did have its effects on Greek phonology with new phonological forms as the result. However, scrutiny of instances is called for on two important counts: chronology of the data used and crossing factors. In addition, the Mycenaean stage of Greek data, at our disposal today, may be more important than a theory on accent of 1896. I, therefore, do not accept Solmsen's explanation of Bóoropos in place of earlier Boóoropos.

An alternative solution of the crux, originated by Karl Brugmann,

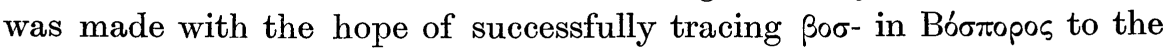
Indo-European level of speech. Though this possibility can no longer be taken into consideration, since it was doubted even by its author, an attempt at definitive refutation seems in order here.

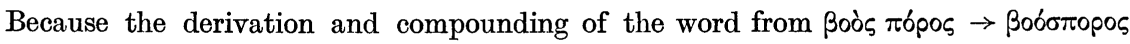
"ox-ford" would hardly have yielded the form ßócropos at the date, let us say, of the early seventh cent. B.C., when the Greeks settled Byzantion, on the ground that the Greek dialects, including Doric, were at that time more archaic than, e.g., is Attic of the fifth cent. B.C., it becomes evident why Brugmann in 1892 set up a special IE form to ac-

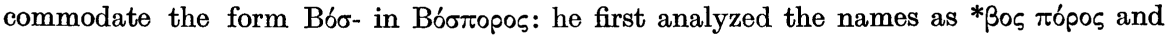
derived the radical noun form * ${ }^{*}{ }_{0}$ s from IE $g^{w_{o s}}$ (vanishing grade $g^{w}-$ ), which he compared with Skt. $g \bar{o}-\grave{s}$ "bovis," whereas the attested Greek form $\beta \circ(f)$ ó $\varsigma$ appeared as a more recent formation like Vedic gávas and Lat. bovis. ${ }^{166}$ While this treatment is repeated in 1906 by setting up the modified form IE $g^{w} w$-os, whence (through * $\beta F_{0 \varsigma}$ ) the form * ${ }_{0} \varsigma$ is received, Brugmann uses a "perhaps" and adds that the term $\varepsilon x \alpha \tau o ́ \mu-\beta \eta$ "sacrificial offer of 100 oxen" (cf. Skt. śata-gu- "possessing 100 cows") also displays the vanishing grade $-g^{w} w$ - in the second component $-g^{w} w \bar{a}-=$ Gr. $-\beta \bar{\alpha},-\beta \eta{ }^{167}$ Yet, the author himself cautiously

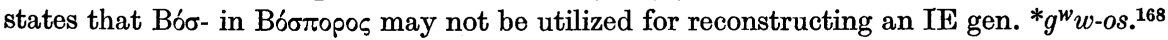
This should have finished the matter for good. However, Brugmann's Greek Grammar, third ed. of 1900 and the fourth reworked by A. Thumb in 1913, adopted $g^{w}$-os for B $6 \sigma-$ in B $6 \sigma \pi$ opos. ${ }^{169}$ Then important authorities of that period such as A. Fick, W. Prellwitz,

165 Solmsen, loc. cit.

${ }^{166} \mathrm{~K}$. Brugmann, Grundriß der vergleichenden Grammatik der indogermanischen Sprachen $^{1}$ (Straßburg), 2 (1892), p. 574 (§ 231), p. 584 (§ 238).

${ }_{167}$ Grundriß, $1^{2} .313$ (§ 344); $2^{2}$ (1906), 134 (§ 79). - On $\dot{\varepsilon} \alpha \alpha \tau \dot{\alpha} \mu \beta \eta$ cf. F. Sommer, Zur Geschichte der griechischen Nominalkomposita (München, 1948), p. 76.

168 Grundriß, 22, 1 (1906), p. 234 note 1.

169 K. Brugmann, Griechische Grammatik ${ }^{2}$, p. 115 ; $^{3}(1900)$, pp. 44 and 177 ; 4th ed. reworked by A. Thumb (1913), pp. 51 and 208 (here in both references with the warning "presumably"). 
and others accepted Brugmann's original suggestion. ${ }^{170}$ The last Indo-Europeanist to record his following suit with Brugmann's original suggestion was, as far as I could ascertain, Hermann Hirt (1921). ${ }^{171}$ For us it is of course certain that the ad hoc reconstructed IE genitive form $g^{w}$ wos is inadmissible. In this sense both F. Solmsen ${ }^{172}$ and E. Schwyzer as well as several others ignored this solution. The fact is that there is no basis for the reconstruction of an IE form $g^{w}$ wos.

In scrutinizing the data, I have come to adopt the Greek etymon of Bóoropos on these grounds: (1) the making of parallel place-names from animal terms is a toponymic practice in many languages, (2) parallel place-names with the appellative noun $\beta 0 \tilde{c} s$ and similar terms are many, and (3) a series of similar compounds in Greek do well support the case of Bóoropos.

Terms for animals are used as designations of rivers, mountains, etc., and there are two aspects in their interpretation: (a) nationalistic interpretation, and (b) mythological motives seen behind the animal terms: $:^{173}$

"wolf": fume del Lupo, le Loup in the area of Nizza, Greek $\Lambda$ úxos (13 times in Greece and Asia Minor)

"horse": Gr. "I $\pi \pi \circ \varsigma$ in Colchis, It. Cavallo, Span. Cavallón (Andalusia)

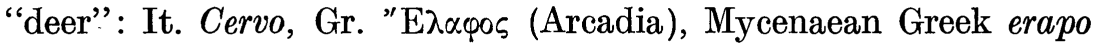

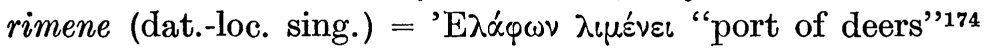

"bull": Gr. Taũpos (mountain in Asia Minor), It. Toro (in E. Italian Alps) ${ }^{175}$

"buffalo": Bufalo rivers and rivulets in the South Italy province of Cosenza and 16 others. ${ }^{176}$

170 A. Fick, "Altgriechische Ortsnamen II," $B B 22$ (1897), p. 11 (*ßos from $\beta$ Fos); W. Prellwitz, Etymologisches Wörterbuch der griechischen Sprache (Göttingen, 1905), p. 81

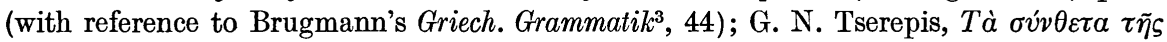

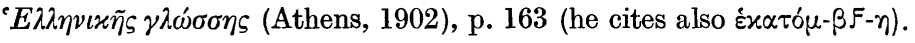

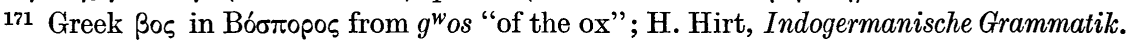

Teil II: Der indogermanische Vokalismus (Heidelberg, 1921), p. 196 (§ 197,1).

172 F. Solmsen, IF 6 (1896), Anzeiger, p. 154.

173 G. Rohlfs, "Europäische Flußnamen und ihre historischen Probleme," Proceed. of the Sixth ICOS (München, 1960-61), 1.14-18.

174 Rohlfs, loc. cit. On the Mycenaean place-name cf. V. Georgiev, "La stratification des toponymes en Grèce ancienne," Proceed. of the Ninth ICOS 1966 (Louvain, 1969), p. 231.

175 On the term taurus "bull" used in geographical names, mainly for mountains, in the Mediterranean ef. K. Finsterwalder, "Der Name der Taurisker usw.," Studien zur Sprachwissenschaft und Kulturkunde, Gedenkschrift W. Brandenstein (Innsbruck, 1968), p. 343 ff.

176 See G. Rohlfs, "Flußnamen im heutigen Kalabrien," $B N F, N F, 4$ (1969), p. 141. The author suggests that the designation may have one of two causes, either figurative usage or mythological animalization. The personal name Boú $\beta \alpha \lambda$ s in Asia Minor from ßoúß $\alpha \lambda_{05}$ "antelope"; L. Robert, Noms indigènes dans l'Asie Mineure gréco-romaine 1 (Paris, 1963), p. $22 \mathrm{ff}$. 
"cow": La Vache enragée in France (Département Cher).

"ox": Italian Monte Bove (Tuscany, Abruzzi Mountains), Valle del Bove (Sicily), Cala del Bove (at the Tuscany coast), Bove Marino (cape south of Syracuse), and Bovo Marino (near Agrigento), etc.; German Ochsenfurt (city on Main), Ochsenbach, Ochsenfeld, Ochsenwerder, Ochsenburg, Ochsenwang, Oxenbronn, Oxlund, etc. ${ }^{177}$

\section{BOY $\Sigma$ IN GREEK}

Boũ $f$. was the name of an Asiatic headland ( $\left.\alpha^{\prime} \times p \alpha\right)$ on the straits north of the point of Byzantion (Polyb. 4.43), apparently identical with a white rock mentioned in Strabo and with a place recorded by Pliny. ${ }^{178}$ This name may have been the origin of the geographic feature Bóoropos.

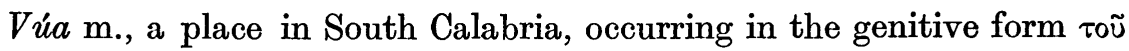
Boós in A.D. 1099, comes from anc. $\delta$ Boũs; ${ }^{179}$ this, I suggest, changed into $\delta$ Boṽ and then into a first-declension noun $\delta$ Bov́ $\alpha(\varsigma)$ and accus.

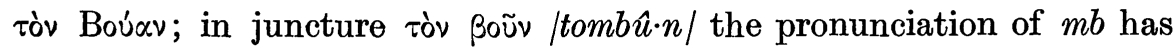
been retained to the present. According to Rohlfs, the same nomin. Bov' $\alpha$ /vria/ was orthographically adjusted into Latinized Bova; $;^{180} \mathrm{I}$ agree with this. The genitive toũ Boós has its parallel in another place-name $\langle\dot{\eta}\rangle$ Bow̃v in Caria (second cent. A.D.). ${ }^{181}$

177 The above examples with "ox" in Italy and Germany were listed for me by Professor Gerhard Rohlfs (per letter dated 2 Dec. 1970), my thanks to whom are here also recorded.

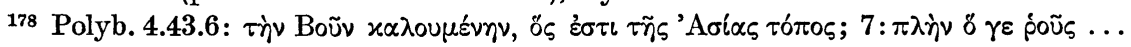

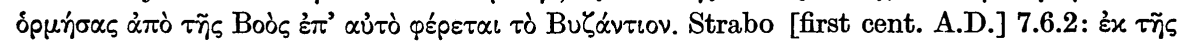

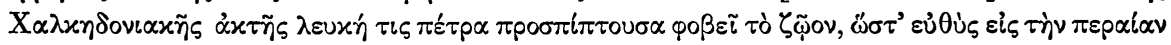
$\tau \rho \varepsilon ́ \pi \varepsilon \sigma \theta \alpha$. Dionys. Byz. [second cent. A.D.], Anaplus Bospori (ed. R. Güngerich), p. 34,

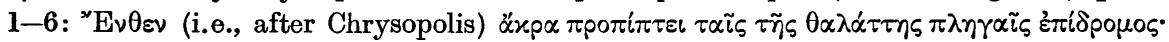

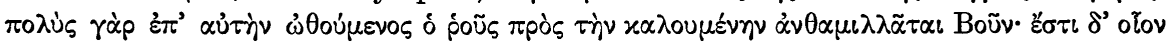

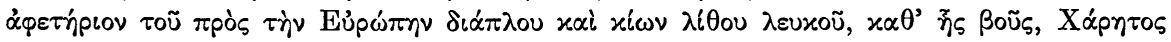

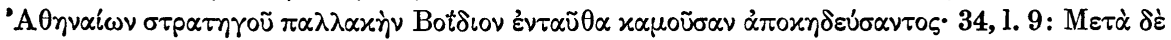

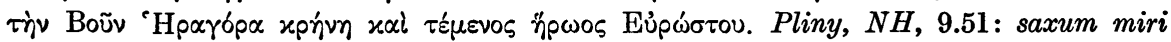
candoris. Cf. Walbank, op. cit., 1.496f. A district of Constantinople called Boũs (first quarter of the seventh cent. A.D.; Chron. Pasch., Bonn ed., p. 382) was the cattle market, the counterpart of Rome's forum boarium, and has, therefore, no significance for geographic

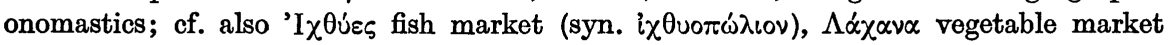

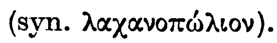

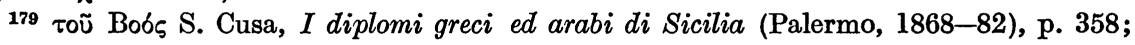
G. Rohlfs, Lexicon graecanicum Italiae inferioris ${ }^{2}$ (Tübingen, 1964), 94.

180 Rohlfs, loc. cit.: o Vúa ène mia máñi hòra "Bova is a beautiful village," páo stom buia "I go to Bova"; inhabitant name Vutáno "inhabitant of Vua" (with -tano certainly analogical from Napoletano, etc.).

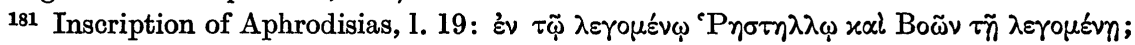
see L. and J. Robert, Carie (Paris) 2 (1954), $233 \mathrm{f}$. 


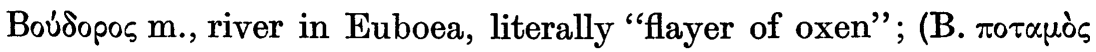

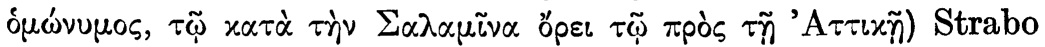
10.1.5.

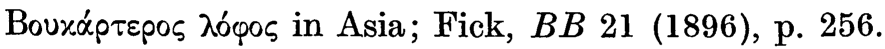

Boúxpavos $\dot{\eta} \pi p o ̀ s ~ X i ́ \omega$ cape: Philostr. epist., ed. Didot; cf. Grasberger 78; Fick, BB 21 (1896), p. 269.

Bouৎáyos m., river in the Peloponnesus, literally "eater of oxen." Box́ypos m., river in Locris ("the Wild Bull"), Lat. Boagrius amnis

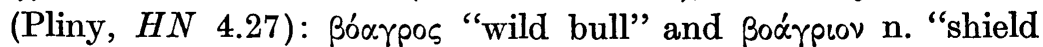

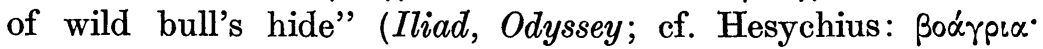
$\dot{\alpha} \sigma \pi \dot{\delta} \delta \alpha \zeta)$.

Boutópos 'Apouvóns, referring to Mt. Athos (Callim. Aitia 110.45,

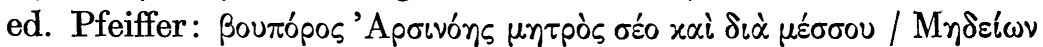

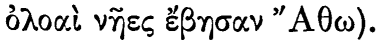

Beside the syntagma Airòs $\pi 0 \tau \alpha \mu o ́ s$, Muòs öpros, etc., the so-called genitive compounds such as 'A

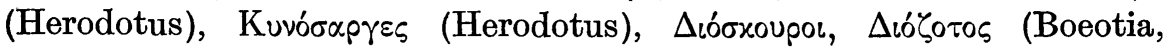

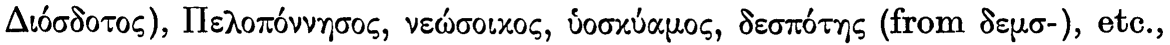
are well known. Here comes also 'E ${ }^{\circledR} \lambda \hat{n} \sigma \pi \circ \nu \tau o \varsigma$ (Iliad, Herodotus) explained

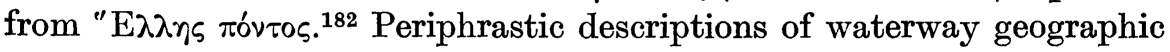
features are also well known, e.g.,

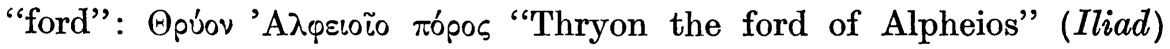

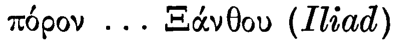

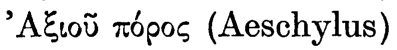

$\pi$ ópov ... "A Avos (Herodotus)

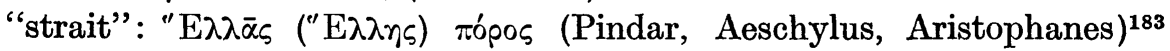

'Ióvios rópos "the Ionian sea as the passage way from Greece to Italy" (Pindar). Merely descriptive are the expressions $\pi$ ópos 'A $\varphi \varphi \varepsilon 0 \tilde{u}$ for

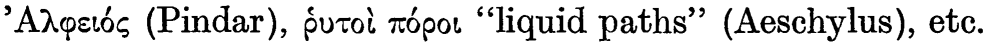

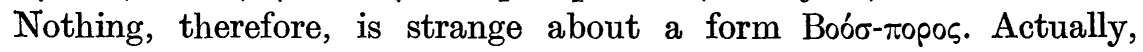
there are attested descriptive names with the genitive Boós or compounds,

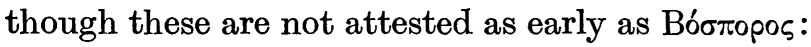

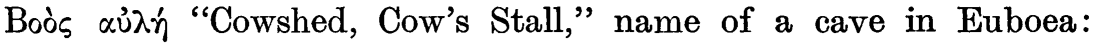
Strabo 10.1.3; cf. Eustathius, Commentarius Il. 536f.; Grasberger, 96 and 302; Fick, $B B 21$ (1896), 283; Epaphos was supposed to have been born by Io in the place called Boòs $\alpha \dot{u} \lambda \dot{\eta}$; Eustathius, op. cit., 278.30; cf. E. Maass, de Aeschyli supplicibus commentatio (Greifswald, 1890), p. xxi; Eitrem, art. Io ('I $\mathrm{\omega}$ ), $R E 9$ (1916), 1735.

Boòs $x \varepsilon \varphi \alpha \lambda \alpha$. "Oxenheads," name of a mountainous area in Asia: Eratosthenes [third cent. B.C.] in Steph. Byz. s.v.; cf. Gras-

182 See above, p. 73.

${ }^{183}$ See above, p. 73. 


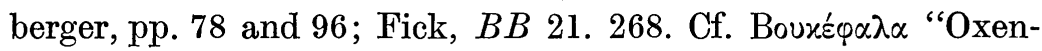
head," town and cape (Grasberger 78, 96; Fick, BB 21. 269).

Boóroupa or Boòs oủpá (or Oủpà ßoós) "Ox- or Cow tail," name of the NE cape in Cyprus: Strabo 14.6.3; Grasberger, p. 125; Fick, $B B$ 21. p. 268. Cf. Kuvóбoupa.

Boòs Mlópos, Orpheus' Argonautica 1059 (ed. E. Abel, Leipzig \& Prague, 1885).

$\mathrm{B}^{\prime} \theta p \varepsilon \pi \tau{ }^{184}$ [ca. A.D. 500] is added here because it may have stood for *Bó $\theta p \varepsilon \pi \tau \sigma^{185}$ just as there are names compounded with Bou-.

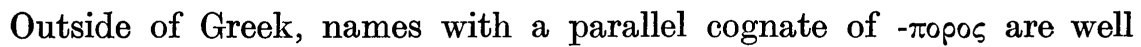
known in many IE languages and in various periods of time:

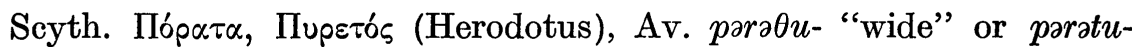
(noun) "passage, crossing," Prut name of the 350 kilometer long tributary of the Lower Danube; ${ }^{186}$ and, on the other hand,

Germanic *furdu, Engl. ford "passage," Germ. Furt (Erfurt, Frankfurt, Klagenfurt, Ochsenfurt city on Main, Schweinfurt, etc.); the Engl. place-name Oxnaford (A.D. 912), Oxenaford (ca. 1000), Oxeneford (1086), and Oxford, which designated a "ford for oxen." 187 There are also six places named Oxford in the United States. ${ }^{188}$ The IE word was *prtú"passage." 189

These place-names hardly need the mediation of a prehistorical substratum to be satisfactorily explained. A Greek name, therefore, designating also "ox-ford" is equally understandable, possible, and even very

${ }^{184}$ Christodorus [poet, $f$. ca. A.D. 500] in Anthologia graeca epigrammatum Palatina cum Planudea, ed. H. Stadtmueller (Leipzig, 1894/99/1906), 1 : Epigrammata Christiana, 9

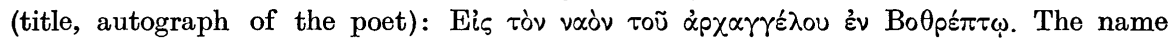
Bó $\theta p \varepsilon \pi \tau \circ \varsigma$ listed in Pape-Benseler, 216a, and rendered in German "Ochsenhof," was also taken over and listed by B. Hansen, Rückläufiges Wörterbuch der griechischen Eigennamen (Berlin, 1957), p. 252, s. $-\pi \tau 05$.

185 Since the name form Bó $\theta p \varepsilon \pi \tau o s$ occurs so late (ca. A.D. 500), its explanation from Boó $\theta p \varepsilon \pi \tau \circ \varsigma$ presents no problems: in Byzantine and modern Greek two adjacent identical

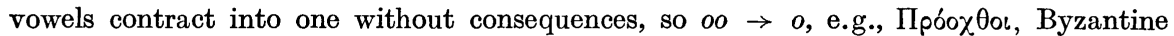

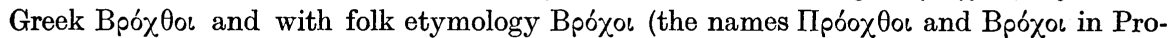

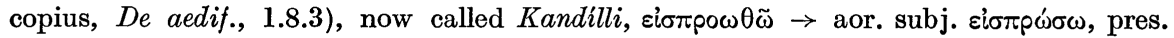

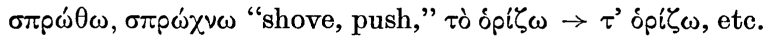

${ }^{186}$ Cf. V. Georgiev, "Die europäische Mikrohydronymie und die Frage nach der Urheimat der Indoeuropäer," Proceed. of the eighth ICOS (The Hague, 1966), p. 190.

187 E. Ekwall, The Concise Oxford Dictionary of English Place-Names (Oxford, 1960), p. 355, s. Oxford; F. Kluge und A. Götze, Etymologisches Wörterbuch der deutschen Sprache ${ }^{16}$ (Berlin, 1953), p. 233, s. Furt.

188 Of these only the one in Idaho is justified by a local story that tracks of oxen were found at a nearby ford; see G. R. Stewart, American Place-names (1970), p. $351 \mathrm{f}$.

${ }_{189}$ Cf. further on Middle Low German vörde, Danish Fjord, etc. W. Laur, "Förden- und Buchtennamen an der Schleswig-Holsteinischen Ostseeküste," Proceed. of the Sixth ICOS (München) 3 (1961), pp. 511-516. 


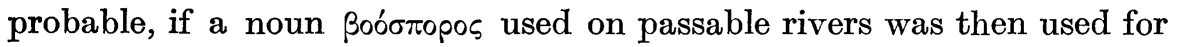
the Bosporos narrows.

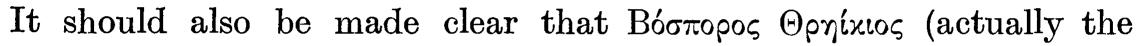

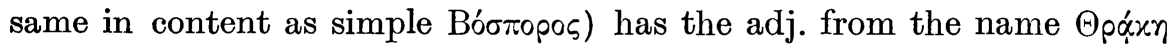

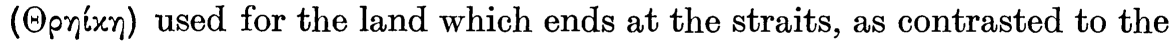

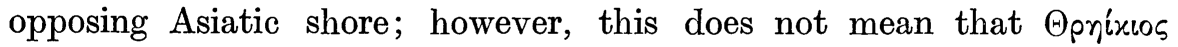
stands for "pertaining to Thracian tribes or tribes that speak the Thracian language," as some scholars obviously have assumed, with the projected

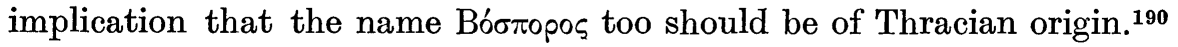
That kind of approach to the matter would be misleading.

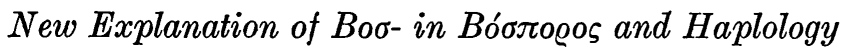

For the better understanding of the early Greek process of develop-

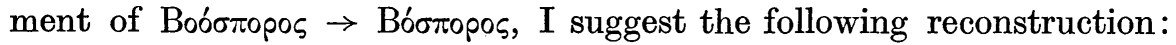
Bofòs tópos and Bofóotopos. The intervocalic - $w$ - (digamma $F$ ) persisted in the Greek dialects of Mycenaean times and later and is found in the epigraphy of the historical period. Thus, Mycenaean Amphílāwos, Arkhélāwos, Ekheláwon, Etewokleweios, Lāwāgétās, Lawodókos, Metálāwos, Perílāwos, etc.; and in inscriptions (in the alphabetical script): A ${ }^{\prime} F \alpha \varsigma$,

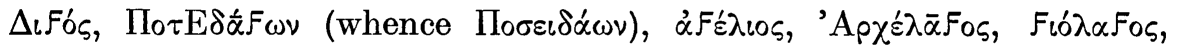

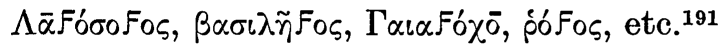

As the Mycenaean form of the IE word for "ox" is $g^{w o w-, ~ e . g ., ~ i n ~ t h e ~}$ man's names Gwow-akseus and Stäti-g ${ }^{w o w e u s,{ }^{192}}$ and the term tópos may have been involved in the man's name Euporos ( $M Y A u$ 102), with the alternative Euphoros, ${ }^{193}$ the name Bofóoropos is the form expected for the seventh century B.C., when Byzantion was colonized by the Greeks. And, when the Greek settlers of the area pronounced at a fast tempo this name, which probably they themselves had given to the narrow strait, it could be subject to change and specifically to shortening; in the tetrasyllabic word Bofó $\sigma \pi \circ$ pos each of the first syllabes contained a bilabial phoneme: $b, w, p$.

190 The name of the Byzantine (sixth cent. A.D.) fortress Bospara in inland Thrace (see above, note 100) occurs relatively too late to carry weight in considering the interpretation of the name Bóoropos that existed over a millennium earlier.

191 On the $F$ in Mycenaean and Homeric Greek see V. Georgiev, "Mycénien et Homérique: le problème du digamma," Proceedings of the Cambridge Colloquium on Mycenaean Studies, ed. L. Palmer and J. Chadwick (Cambridge, 1966), pp. 104-124 [here also on Corinthian $\Pi о \tau E \delta \bar{a} F \bar{o} v \iota$ with original $F$ pace Heubeck; see next item]; cf. A. Heubeck, “'Digamma'-Probleme des mykenischen Dialekts," Die Sprache 9 (1963), pp. 193-202; idem, "Zu mykenischen Namen und Titeln," IF 64 (1958), p. $119 \mathrm{ff}$.

192 See M. Ventris and J. Chadwick, Documents in Mycenaean Greek (Cambridge, 1956), p. 424f.; J. Chadwick and Lydia Baumbach, "The Mycenean Greek Vocabulary," Glotta 41 (1963), p. 180 (s. ßoũs).

193 Ventris and Chadwick, op. cit., p. 418; Chadwick and Baumbach, op. cit., p. 238. 


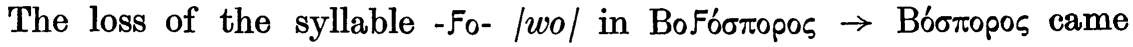
about, I submit, as the result of the phenomenon called syllabic dissimilation or haplology. This phonological phenomenon, usually affecting long words, is an observable fact in spoken languages and the examples from the history of ancient and modern languages are legion. From Greek we may mention a few:

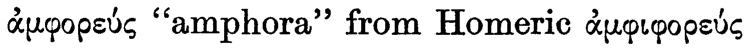

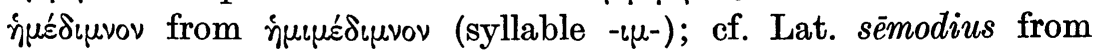
sēmimodius

xióxpavov from xıovóxpavov (syllable -vó-)

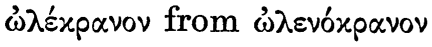

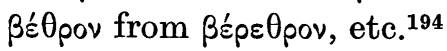

In many examples we observe that the dissimilated consonant of the lost syllable is identical with that of another syllable in the word, e.g.,

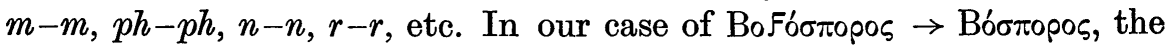
consonant of the lost syllable is not identical with the consonants of the retained syllables but it is bilabial, i.e., of the same place of articulation, as they are. This is also possible in haplology, as we see in examples such as

$$
\begin{aligned}
& \alpha \dot{u} \tau 0 \theta \dot{v} v \tau \eta s \rightarrow \text { } \rightarrow \dot{u} \theta \dot{\varepsilon} v \tau \eta s^{195}(t-t h ;-\tau o-\text { lost })
\end{aligned}
$$

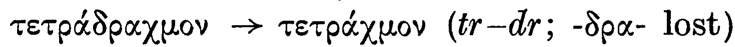

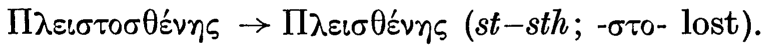

Other equivalents, involving $F$ and another bilabial consonant, are

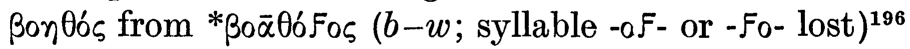

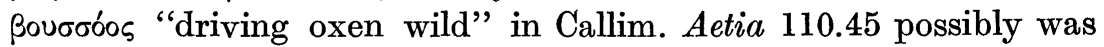

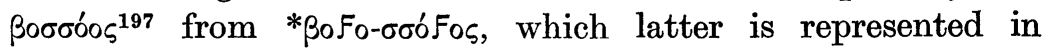
Nonnos: $\beta 00 \sigma \sigma o ́ o 5 .{ }^{198}$

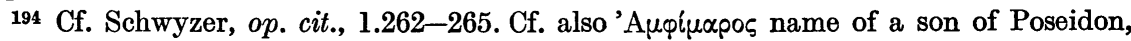

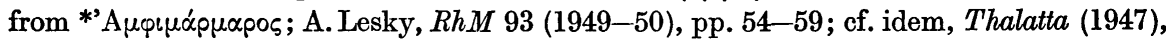

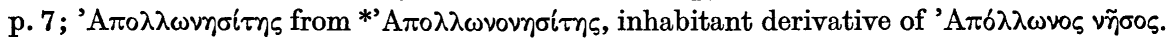

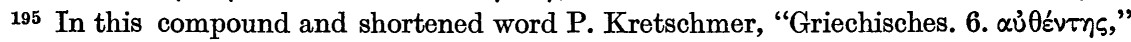
Glotta 3 (1912), pp. 289-293. However, it seems that P. Chantraine is correct in rejecting this etymology and deriving $\alpha \dot{v} \theta \dot{\varepsilon} v \tau \eta s$ from $\alpha \dot{u} \tau 0-$ and $\varepsilon^{\prime} v \tau \eta s$ (another compound is He-

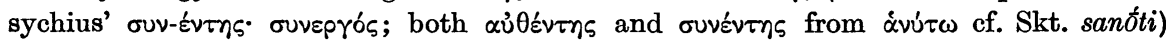

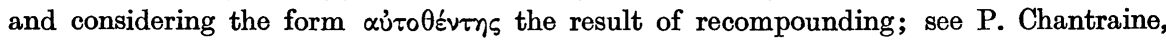

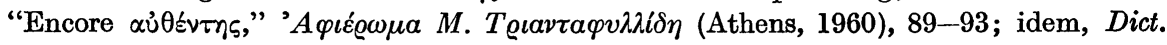
etym. 1 (1968), p. $138 \mathrm{f}$.

196 The reconstructed form $\beta 0 \tilde{\alpha} \theta 6 F_{0 \zeta}$ "hasting to the cry for help, helping, aiding" (Iliad; "helping, aiding" Pindar; from $\beta \circ \bar{\alpha}$ and $\theta \delta F_{0 \varsigma}$, this from * $\theta \varepsilon f \omega$ "run") with loss of intervocalic - $F$ - yielded Doric $\beta \circ \bar{\alpha} \theta 6$ os (inscription of Epidaurus, IG 4.1, No. 128, 1. 60; name of a Delphic month) and Ionic $\beta$ on $\theta 605$, on the other hand, with haplology $\beta 0 \bar{\alpha} \theta$ [ $6 \mathrm{~F}$ ] os:

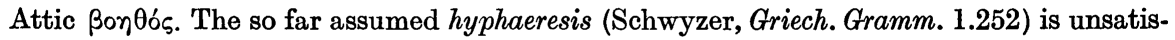
factory because it describes but does not explain the data.

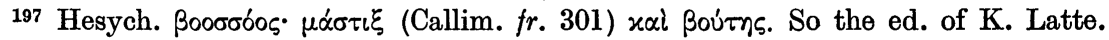

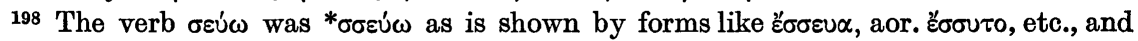
is from IE *kyew-, whence also - $\sigma \sigma \delta F_{0 \varsigma}$ as in $\lambda \alpha 0-\sigma \sigma o ́ \circ \varsigma$ "rousing or stirring men" (Homer). 


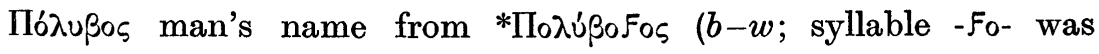

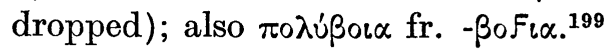

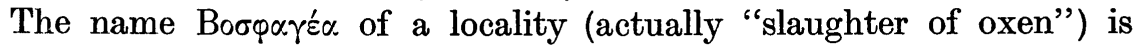

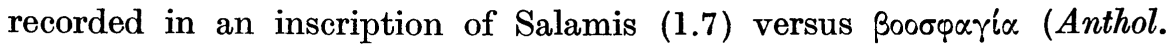
Pal. 16.101). ${ }^{200}$

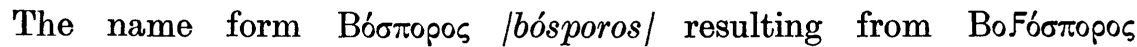
/bowósporos/, therefore, is understandable with haplology at work ${ }^{201}$ and the explanation is, I hope, satisfactory and convincing as is not that with the alleged surreptitious loss (hyphaeresis) of the one of the oo in

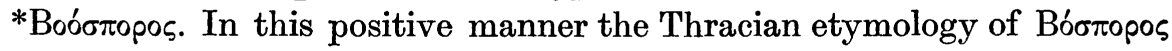
is unequivocally dispatched to oblivion.

\section{CONCLUSION}

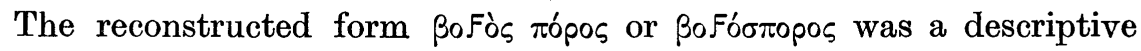
designation for "a narrow channel, strait." The assumed appellative was either original or a geographic name that was substantivized. If it was geographic, it meant to convey the notion of a seaway from sea to sea, and as such could be applied to the Thracian Bosporos, the Hellespont, and the Cimmerian Bosporos. As to the original naming Bosporos, we may assume that this occurred at Byzantion, in whose area the headland $\dot{\eta}$ Boũ 5 "The Cow," on the Asiatic side NE of Byzantion, might have pre-existed. Since that place was called Boũs, the seaway could take the

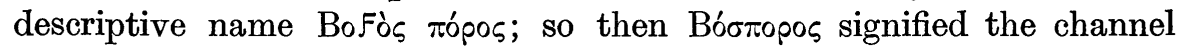
( $\pi_{0}^{\prime} \rho \circ \varsigma$ ) at the promontory Boũ , i.e., the narrow seaway from the Propontis to the Black Sea. In chronological order, the name Bóoropos at Byzantion could have been first and then it could have been transferred and applied to the Hellespont and the Cimmerian isthmus.

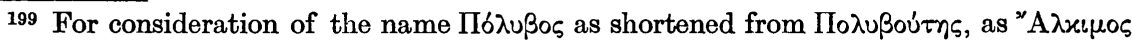

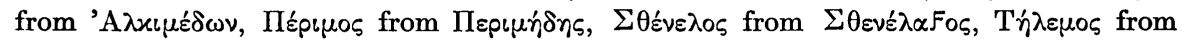
Tๆ $\lambda \varepsilon^{\prime} \mu \alpha \chi 0 \varsigma$ see E. Risch, Wortbildung der homerischen Sprache (Berlin, 1937), 205f. Still

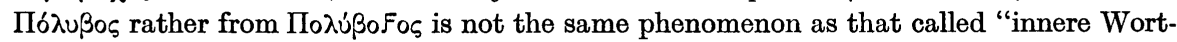
kürzung," discussed by P. Kretschmer, Glotta 31 (1951), p. 104f. The proparoxytone form

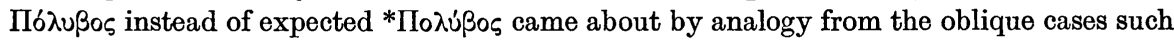

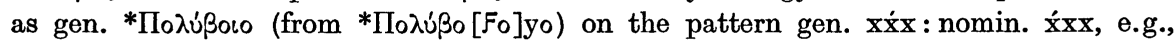

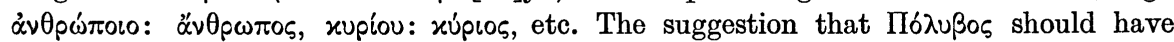
derived from a reconstructed form $* \Pi \circ \lambda u-\beta F-o s$ (cf. Tserepis, op.cit. [above note 170], p. 437) with $\beta F$. from $g^{w} w$ - is out of the question; cf. Sommer, op. cit. [above note 167], p. 76 note 3 .

${ }^{200}$ See A. Wilhelm, "Inschrift aus Salamis," Anzeiger d. Akad. d. Wiss. in Wien, philos.-hist. Kl., 64. Jahrg. (1927), pp. 212-222, especially pp. 214, 215, 217, 222; cf. IG II $^{2} .1590$ a, p. 810 (addenda et corrigenda).

201 Doric (Rhodian) Boxó $\pi \iota \alpha$, neut. plur., name of a festival at Lindos (IG 12(1). 792,

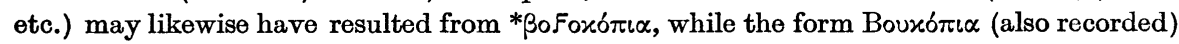
would be a later analogical adaptation to the numerous $\beta$ ou-compounds. 
The appellative noun $\beta$ óøropos, I reason, could have applied originally at crossing-points of rivers and only then it could have been transferred to channels of seaways. ${ }^{202}$ Otherwise, one has to assume that cattle were really able to swim across the strait, which is on two counts, i.e. the strong current and the distance, impossible. Exactly at the narrowest point of the Bosporos there occur most drownings on account of the strong current. ${ }^{203}$ While, therefore, the original meaning of the term Bóoropos

202 The original meaning of compound words is lost by the fact that part of the se-

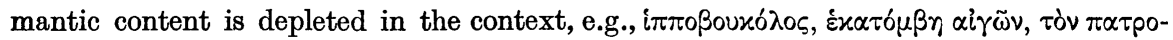

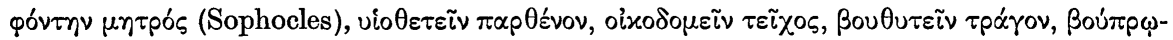

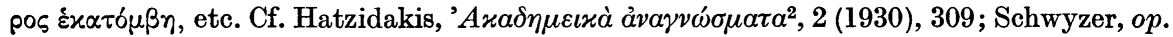
cit., 1. (1939), p. 426. It is, therefore, possible that B6́rлороร "a narrow seaway of an Ox" meant simply "narrow seaway."

${ }^{203}$ Information on drownings in Bosporos was given me by Prof. George G. Arnakis, Univ. of Texas, who lived in the area during his early years (per letter 12 Nov. 1970).

Concerning the possibility of cattle swimming and crossing waterways, I addressed my inquiry to my colleague, Prof. Paul Kannowski, head of the Department of Biology at the University of North Dakota. Through his services Prof. M. L. Buchanon, head of the Department of Animal Science, North Dakota State University, and Prof. Jay C. Meiske, Department of Animal Science, University of Minnesota, were contacted. To the three gentlemen I am very grateful for their helpful contribution on this matter.

The facts established are these: almost any mammal and, therefore, cattle can swim, though the distance is to be ascertained from many cases. Dr. Jess Williams of the Dairy Section, University of Minnesota, who is from Texas, assured Prof. Jay C. Meiske that he has seen cattle at least "float" a mile. Professor Meiske adds, "Apparently, cattle are natural floaters and, if they have grown up in areas that periodically have high water, they do not fear it and readily ford streams" (per letter dated 17 Nov. 1970). Professor Kannowski, after contacting Professor Buchanon, has been assured that cattle "swam at least one quarter of a mile during a flood in Oklahoma. He (Professor Buchanon) also stated that how far cattle could swim would depend upon their condition. Animals in good condition should be able to swim that distance but they would likely be nearly exhausted. A strong current would increase the difficulties in getting across" (Professor Kannowski per letter dated 9 Nov. 1970).

If we properly evaluate the foregoing information, we have the fact that cattle can float in high waters and ford a stream and from these known cases we do know that a quarter of a mile or even a mile for cattle is a possible swimming or floating distance. Mr. Buchanon stresses that difficulties during swimming across would increase on account of a strong current.

In the case of the straits in the Byzantion area three important factors present themselves: (a) the narrowest point in the Bosporos is ca. 550 meters between Anadolu Hisar and Rumeli Hisar (and the widest is a little over three kilometers) and has steep shores; the narrowest point in the Hellespont is ca. 1200 meters; (b) the depth of the water is several tens of meters; and (c) the current of the Bosporos and the Hellespont is rather very strong. The conclusion, therefore, is inescapable that the crossing of these straits by oxen is precluded. A corroboration of this conclusion comes again from Professor Arnakis, who (in the aforementioned letter) informs me that it is unknown that cattle ever swam across the Bosporos channel in modern times.

I reason, therefore, that the term bósporos "ox-ford" was applied earlier to fordable rivers and subsequently to these three channels called Bósporos. The common point of 
was "ox-crossing-point" of a river and simply "river-crossing," its meaning applied to our case was "strait, channel" in its length. This assumption, which makes sense to me, will, I hope, appeal to others also on the ground that the two channels, the Hellespont and the Bosporos, are called $\Sigma_{\tau \varepsilon v o ́ v}($ and $\Sigma \tau \varepsilon v \alpha$ ) "narrow, strait" and by the Turks Boğazı (= the Bosporos) and Çanakkale Boğazi (= the Hellespont). These names, in fact, apply to the narrow seaway, not to an "ox-crossing, ox-ford." In Modern Greek I was able to uncover a hapax, one toponym oi Boï dó$\pi$ opor in Aris of Messenia from the archives of the Historical Lexicon, ${ }^{204}$ which is to be explained from a noun Boï ónopos m. "ox-ford." In any case, the term rópos very well stands for the maritime river called by

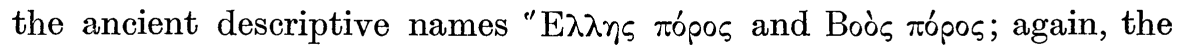

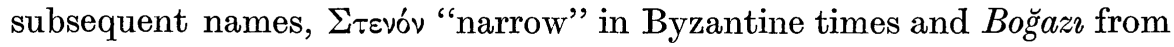
the inception of the Turkish period on testify in favor of the meaning "passage of the seaway, narrow waterway, strait."

The mythological association of the name Bó $\pi$ opos (in the Byzantion area) with Io was, I suggest, a rather late additive as an aetiological explanation of the name. ${ }^{205}$ The mythical element had, in fact, nothing to do with the actual etymon of the name except for the lexical element (Boũs) used also in the post factum popular explanations. See the appendix.

reference for both rivers (that are fordable) and these channels (that are not fordable) being the narrowness of the waterways, the application of the term bósporos to these seaways was not amiss.

${ }^{204}$ Dr. Dikaios Vayacacos, Director of the Historical Lexicon, kindly passed this information to Dr. John Thomopoulos (Dec. 1970), upon my inquiry. Further and more precise information on this point I received from Mr. Nikos Zervis (Kalamata, Greece, per letter 12 Feb. 1971): o o Boïðóropo /voyðópori/ is a toponym on the river Pamisos, i.e. a

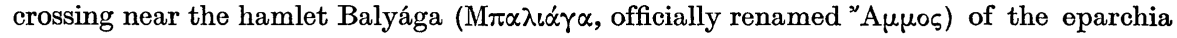
Messene; in earlier times, oxen crossed the river on that point. In modern Greek I was unable to uncover a term "cow-ford" ( $\dot{\alpha} \gamma \varepsilon \lambda \alpha \delta \delta$ ' $\left.\pi \circ \rho_{0}\right)$ to designate a river crossing-point. This certainly does not mean that such terms did not exist or, for that matter, do not exist; they may simply be unrecorded. Actually, I expect to find more such toponyms in existence.

205 This differs from V. Burr, Nostrum mare (1932), p. 26, who reasons that the Io saga is very old, in the following: The Io saga is very old but the geographical ingredients come to it after the opening of the Black Sea and through the penetration of Greek seafarers in the seventh or even eighth century B.C. See above, p. 72 with note 13 and addenda, p. $120 \mathrm{f}$. 


\section{APPENDIX TO BOSPOROS:}

\section{A NOTE ON THE MYTH OF IO ${ }^{1}$}

Long before history began, a considerable number of myths were localized in the Black Sea area ${ }^{2}$ and these might be used as indirect evidence to show the Greeks' knowledge of the Pontus, though we depend on comparatively late sources. Our early sources, Homer and Hesiod, locate no myths explicitly in the Pontus. Yet, one of the great genealogical trees of the (Hesiodic) Catalogue was the genealogy or descendants of Io. The interest of the poet was of a geographic order and he who wished to give a geographic picture of the world had to make use of the language and the legend. ${ }^{3}$ A. J. Graham discusses examples of myths and sets out some principles: the story of Achilles, Prometheus' punishment in the Caucasus, the story of the Amazons, the exploits of Heracles, the story of the Argonauts, and specifically, the myth of the wandering rocks

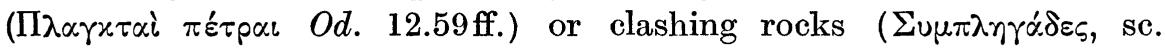

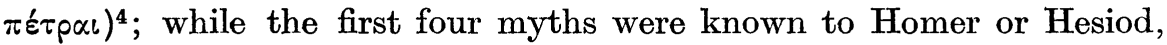
the localization in the Pontus area seems to have come later. ${ }^{5}$

Aristeas' fragmentary poem embodied the experiences of an actual voyage undertaken by its writer beyond the Pontic regions and into Central Asia in the later seventh cent. B.C. In a study of Aristeas and his poem (published in 1962), J. D. Bolton makes a case for this and further suggests it as a likely source for the local geographic description of Io's journey as detailed to her in advance in Aeschylus' Prometheus Bound, written two centuries later. ${ }^{6}$

In the last three decades of this century, advances have been achieved toward our understanding of some Greek myths derived from the early Near East civilizations, this of course also in the broader framework of literary influence from the same regions. ${ }^{7}$ Egypt too has had its share.

1 See the bibliography noted in the following addenda, below, p. $119 \mathrm{f}$.

2 Listed, e.g., by O. Gruppe, Griechische Mythologie und Religionsgeschichte (1906), sections 136-138.

${ }^{3}$ R. Merkelbach, "Les papyrus d'Hésiode et la géographie mythologique de la Grèce," Chronique d'Égypte (Bruxelles) 43 (1968), 139.

4 A. J. Graham, BICS 5 (1958), 36f. The two (Wandering or Clashing Rocks) are considered as different; cf. C. Robert, Die griechische Heldensage (3 Bücher, Berlin, 1920-21), 825-827. But the story is essentially the same in both; cf. H. J. Rose, art. Symplegades, $O C D^{2}(1970), 1028 \mathrm{a}$.

5 Graham, op. cit., 37.

6 See S. Piggott, "Iron, Cimmerians, and Aeschylus," Antiquity 38 (1964), 300-303, especially 302.

7 As an example see H. Otten, "Vorderasiatische Mythen als Vorläufer griechischer Mythenbildung," Forschungen und Fortschritte, 25. Jahrg., H. 13/14 (1949), 145-147. 
While Io is supposed to have acquired a late association with the Bosporus and the Caucasus, her earliest association was with Egypt. On this aspect we have at our disposal a recent study by Ruth I. Hicks on four stories that seem to have borrowed, or to have been influenced by, Egyptian elements. ${ }^{8}$ These mythical elements were introduced into Greek mythology either in the Mycenaean period (ca. before 1200 B.C.) or during the Egyptian twenty-sixth or Saite dynasty (664-525 B.C.), while for half a millennium (ca. between 1200 and 664 B.C.) Egypt was closed to the inhabitants of the Aegean world. It should be stated that, while the majority of extant literary and graphic representations of the stories with an Egyptian locale are no earlier than the sixth century B.C., the myths themselves seem to be older by centuries. ${ }^{9}$

Jean Bérard's novel and detailed suggestion on the legend of Io and her descendants in connection with the period of the Hyksos, "the kings of foreign countries," who are supposed to have been of an essentially Semitic character and to have come to Egypt from the Syrian and Palestinian region, at the end of the Middle Bronze period, and on the adventure of Io and her descendants not as a purely Egyptian episode but rather as an episode of Phoenician history in Egypt, has to be taken into serious consideration, as the only simple strong possibility, as Mr. Bérard claims. The relations among the Greek legend of the descendants of Io, that of Phaëthon, and the story of Joseph have to be considered as established, he thinks; in each of these three cases it is seen how fabulation intervened to deform and transfigure a historical reality. The legend of Io and of her lineage - says Bérard - responds in truth to historical facts, the descendants of Io representing in effect the last Hyksos, who were expelled from Egypt ca. 1580 B.C. ${ }^{10}$ The adventure of Aigyptos and the return to Greece of Danaos and Kadmos correspond to that expulsion of the Hyksos.

[This refers mostly to the Theogony of Hesiod and the Boğazköy (of the thirteenth cent. B.C. or earlier) and Ras-Shamra texts as well as to Typhon, who is supposed to render Canaanite (Baal) Zaphon, wherein the Phoenicians served as intermediaries between the Canaanites and the Greeks.]

8 Ruth I. Hicks, "Egyptian Elements in Greek Mythology," TAPA 93 (1962), 90-108. [The only weakness of this piece of work is that the author was unaware of studies on Io that had appeared before 1962, so A. Severyns (1926), J. Vürtheim (1928), Ch. Josserand (1937), U. Pestalozza (1939), J. Bérard (1952 and 1957), and others; there has of course also been a number of more recent studies since 1962. See bibliography below, p. $119 \mathrm{f}$. (As is well known, Année Philologique is our best bibliographical tool in this respect.)]

9 Hicks, op. cit., $92 \mathrm{f}$.

10 See Bérard, Syria 29 (1952), 41-43; idem, Revue de l'histoire des religions 51 (1957), 221-230. On the Hyksos cf. T. Säve-Söderbeg, "The Hyksos Rule in Egypt," Journal of Egyptian Archaeology 37 (1951), $53 \mathrm{ff}$. On the negative results of Eusebius' chronology about To see Bérard, Syria 29.7 and 11. 
Bérard's theory may be discussed by his fellow expert authorities. If I cannot follow Mr. Bérard in his conclusions, it is because many details are not self-evident, as he thinks they are.

In any case, B. Landsberger and R. D. Barnett support the view that the Phoenicians were intermediaries in cultural diffusion (art, technic, etc.) in the Near East. ${ }^{11}$

Scanty fragments have preserved Io's story for us but we complement them by drawing on later authors who had more material than we do. The original form of the Io myth, therefore, is no longer represented in the first account of the legend of Io as provided in Greek literature, i.e. in Aeschylus, Prom. $589 \mathrm{ff} ., 681 \mathrm{ff}$; Suppl. $538 \mathrm{ff}$., 572. This is so because the Io myth is the amalgam of diverse elements and the Aeschylean narrative drew on the epic poem called Danaïs, whose redaction was placed by U. von Wilamowitz in Cyrene in the sixth century B.C., while E. Maass traces the stories of Apollodorus and Hyginus (essentially not different from that of Aeschylus) back to the (Hesiodic) Catalogue. ${ }^{12}$

The main sources of the myth of Io are well known. ${ }^{13}$ The four essential points of the story are (a) Io's position as priestess of Hera at Argos, (b) her transformation into a heifer (with whom Zeus in theriomorphic shape united), (c) her journey to Egypt, and (d) the birth there of a son, Epaphos, fathered by Zeus. The fact that Hera's cult at Argos seemingly dates from Mycenaean times ${ }^{14}$ lends support to the assumption that Io was contemporary with the Egyptian eighteenth dynasty (fourteenth cent. B.C. or earlier), when there was direct contact between Egypt and southern Greece, including the Peloponnesus and the Argolis. Two data, i.e. the discovery of votive offerings of cows at the Argive

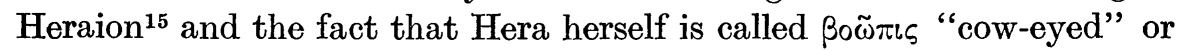
"having large eyes" (Iliad 1.551), are significant, as Hicks stresses.

The thesis advanced by J. Harrison that the cow-headed Io is another form of Hera ${ }^{16}$ has been repeatedly proposed by various scholars. Thus, Farnell assumes this for the earliest times, though he disproves Miss

11 C. D. Barnett, "Early Greek and Oriental Ivories," JHS 68 (1948), 1.

12 Ch. Josserand, "Io et le taon," L'Antiquité Classique 6 (1937), 259.

13 (Hesiodic) Catalogue [second half of the eighth cent. B.C.], ed. R. Merkelbach and M. West (1967); there probably was a genuine Hesiodic core to the Catalogue but much of it cannot be by Hesiod (cf. A. Lesky, A History of Greek Literature [London, 1966], 103f.), so the Catalogue is placed in the sixth century (cf. M. L. West, art. Hesiod, OCD ${ }^{2}$ [1970] 511, §4; Aeschylus, Prom. 561-886; Suppl. 291-315, 531-594; Diodorus Sic., 5.60.4; Apollodorus, 2.1.3; Ovid, Metamorphoses, 1.588-750; Hyginus, Fabulae, 145).

14 M. Nilsson, Mycenaean Origin of Greek Mythology (Berkeley, 1932), 63; cf. Rhys Carpenter, "Argeiphontes, a Suggestion," $A J A 54$ (1950), 182; cf. now Hicks, op. cit., 93.

15 C. Waldstein, The Argive Heraeum (Boston, 1905). The reference in Hicks, 93, note 15 .

16 J. Harrison, Classical Review 1893, p. 74. 
Harrison's theory. ${ }^{17}$ C. Robert and A. B. Cook also take it that Io was a byform of Hera ${ }^{18}$ or that Hera's priestess was originally regarded as Hera incarnate. ${ }^{19}$ Even most recently (though without being based on independent research) it is stated that Io is to be derived from the cult cycle

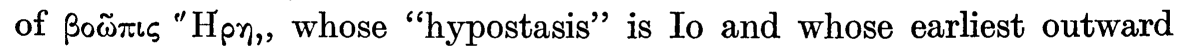
shape she reflects. ${ }^{20}$ Also Hicks considers it possible that in Io we have Hera by another name. ${ }^{21}$

\section{The name 'I $\omega$}

The name of the mythical Io was in use also as a personal name for girls, so in the second cent. B.C., ${ }^{22}$ in the same way as "E $E \lambda \eta \eta$ and $\Phi$ pi $\xi_{05}$ were. As for the etymology of the name, attempts have been made but with no success as yet. The ancient attempt by Herodian to connect 'I $\omega$ ' with an alleged noun ' $i \omega$ " "moon" ${ }^{23}$ is suspect as isolated testimony and because it sets as proved the thesis that Io was a moon goddess, which she was not. The same motive underlay the suggestion by $\mathrm{L}$. Ross that the name is related to the Coptic noun ioh "moon" on the ground that 'I $\mathrm{\omega} \omega$ as a moon-goddess corresponded to Ioh, a moon-god. ${ }^{24}$ Other views of the name were of a shortened form of a longer name such

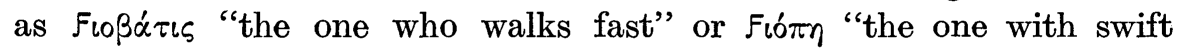
feet" ${ }^{25}$ or with iós "virus" as 'Io $\alpha \dot{\alpha} \mu \alpha$, 'Ió $\lambda \eta$, and this on account of the tales about healing demons at the Argive Heraion. ${ }^{26}$ And most recently,

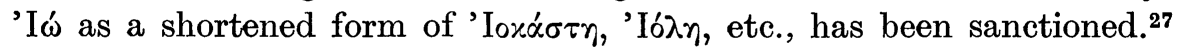
I do not preclude such an explanation but I would eliminate the idea that iós which had an earlier form Fiøós = Lat. vīrus, would explain 'I $\omega$ from * Fi $\sigma \omega$. The reason is that other words connected with 'I $\omega$ such as 'Ióvros linked with 'I $\omega$ ' (Aeschylus, Prom. 840) (vis-à-vis 'Iaóvios, 'Í́vios) present difficulties ${ }^{28}$ and *'Í́foves confirmed by Mycenaean, has an unknown etymology. ${ }^{29}$

\footnotetext{
17 L. R. Farnell, The Cults of the Greek States, 1 (1896), 199-201.

18 C. Robert, Die griechische Heldensage, 1 (1920), 253; A. B. Cook, Zeus, 1 (1914), 453 [with references].

19 Cook, loc. cit., with notes.

${ }^{20} \mathrm{H}$. von Geisau, art. Io, Der Kleine Pauly 2 (1967), 1427.

21 Hicks, op. cit., 93.

${ }^{22}$ Pap. Tebtunis 740 (second cent. B.C.): 'Í́ f.; D. Foraboschi, Onomasticon alterum papyrologicum (Milano, 1970), p. 153.

${ }^{23}$ Herodian, ed. Lentz, 1.347.30.

${ }^{24}$ L. Ross, Italiker und Gräken, p. 84 (cited by R. Engelmann, in Roscher's Lexikon d. Mythol. 2.269); cf. A. B. Cook, Zeus 1 (1914), 455.

${ }^{25}$ E. Maass, $I F 1$ (1892), 168; rejected by O. Gruppe, 2.460 note 5.

26 O. Gruppe, Griechische Mythologie, 2.460.

27 H. von Geisau, art. Io, Der Kleine Pauly 2 (1967), 1426.

${ }^{28}$ Cf. Baumont, JHS 56 (1936), $204 . \quad 29$ Chantraine, Dict. étym. 475, s. "I $\quad 2$ ves.
} 
I find no support for the Egyptian character of Io from her name. The name 'I $\omega$ ' was connected with a "great royal spouse," called Inni, attested for the Hyksos by many scarabs ${ }^{30}$ but this has been doubted. ${ }^{31}$ For another attempt at an explanation, ' $I \omega$ ' is supposed to be a Hellenization of an Egyptian term for "moon" or "ox" 32 but the statement is vague and unconvincing.

\section{The cow form}

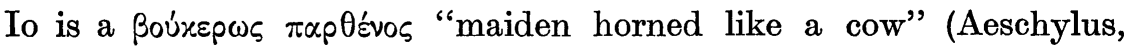

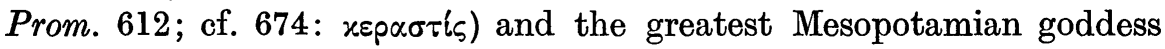
under different names, one being Ishtar, bears the bovine horns; she is the wild cow that devastates the region, the sacred cow, while the king (who is also her son) is called the young bull; she is the divine maternal cow. But Io is different; she is a mixture of cow and maid (Aeschylus,

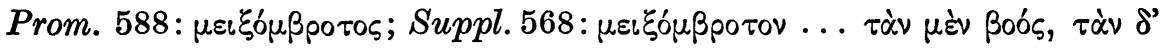
$\alpha \tilde{\text { ruvalixós. }}{ }^{33}$

In any case, the cow form may be a characteristic of Egypt, where the cow had been held in reverence since early times. Hathor, the most prominent cow-goddess, enjoyed a very ancient cult, was associated with the sun god Ra as the latter's wife, was a mother goddess of similar function, particularly with the goddess Isis.

Then the name Eư $\beta o \iota \alpha$ was a cult epithet of Hera at Argos ${ }^{34}$ and " $\mathrm{H} \rho \alpha$ Eü $\beta \circ\left\llcorner\alpha\right.$ was depicted in a statuette found in the Chersonesus Taurica. ${ }^{35}$

30 On Inni see R. Weill, La fin du Moyen Empire égyptien (Paris, 1918), 780.

31 See J. Bérard, Syria 29 (1952), 38.

32 Hicks, op. cit., 93.

33 Engelmann, "Die Io-Sage" (1903), 37; Hicks, op cit., 95. Representations from the Io saga start in Attic vase painting perhaps ca. 540 B.C. and, first of all, with the killing of Argos by Hermes (full references in the following item, p. 90, note 147). Konrad Schauenburg lists seven such vases (one crater and two each of amphorae, hydriae, and oinochoae) from South Italy and several vessels of those carried on the head and located in Bari, Los Angeles and in the Petit Palais in Paris; K. Schauenburg, "Götterliebe auf unteritalischen Vasen," Antike und Abendland (Hamburg) 10 (1961), $90 \mathrm{f}$.

The earliest instances of the Io myth in Greek art represent her as a heifer (so all monuments before the Persian Wars); the change to a horned maiden occurred ca. 470 B.C.

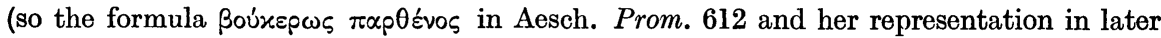
art); cf. J. C. Hoppin, Harvard Studies in Classical Philology, 12 (1901), 335-345.

Cf. U. Pestalozza, "BO $\Omega \Pi I \Sigma$ ПOTNIA 'HPH," Athenaeum, NS, 17 (1939), 106, $113 \mathrm{f}$. P.'s study $(106-110,137)$ is devoted to Hera as a non-Hellenic Mediterranean divinity, and the Argive Io myth is used for his purposes; his work has been largely superseded by recent investigations.

34 R. L. Farnell, The Cults of the Greek States, 1.182.

35 U. Pestalozza, Athenaeum, NS, 17 (1939), 111, note 3.

${ }^{36}$ M. P. Nilsson, The Minoan-Mycenaean Religion and its Survivals in Greek Religion (London, 1927), 431. Cf. Pestalozza, op. cit., 105. 
The Argive goddess was unquestionably connected with the cow..$^{36}$ Furthermore, the hill on which the Heraion stood was called Eüßoc "the rich in cows," an epithet relating purely to Hera's cult; this was a sufficient reason for P. Friedländer's considering the saga Argive. ${ }^{37}$ The cult epithet, however, could be a coinage much later than the association of Hera and Io with the cow.

The equation of Io and Isis is impressive and, furthermore, Io's lineage of descendants such as granddaughter Libya, great-grandson Belos, etc., demonstrates the connection of Greek deities with Egypt and Libya; also Libyans and Greeks are connected with Egypt. ${ }^{38}$

Io and Isis were thought to have been moon goddesses ${ }^{39}$ and the cow horns of both were explained by speculation as a quarter moon. ${ }^{40}$ This misinterpretation, to which even Hicks succumbed, has had its source

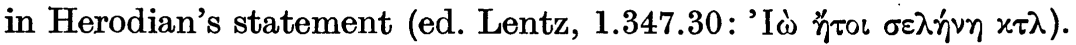

In Egyptian art, Hathor is represented as a cow or a cow-headed woman or a woman with two horns on her head. Owing to the fusion of Hathor and Isis, the combined deity Hathor-Isis is usually portrayed with horns and a disc in late Egyptian art. These representations may well have played a part in the development of the Io myth. Egyptian iconography seems to have exerted an influence on Greek myths. In the case

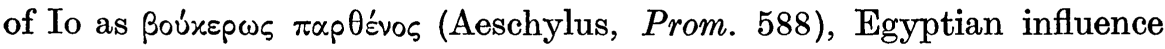
is considered. In Hick's opinion, at the Argive Heraion during Mycenaean times Hera became associated with cows and the detailed story of the cow-maiden (this possibly being another form of Hera) arose when the Greeks had seen the half-animal and half-human Egyptian statues and learned of Hathor's cult. ${ }^{41}$

In addition to the Egyptian basis and features, the Io myth definitely also comprises Greek aspects: (1) Zeus' love for Io and the resultant jealousy of Hera (this being paralleled in many other Greek myths). ${ }^{42}$ (2) The metamorphosis of Io, which is not at all uncommon in Greek

37 P. Friedländer, Argolica, 23; Farnell, loc. cit.; cf. Pestalozza, loc. cit. L. Deubner (Philologus, NF, 18 [1905], 490ff.) refers this place-name to the island Euboea, which he identifies as the native land of To.

38 Cf. G. Kahlo, "Die blonden Libyer," Helikon 1 (1961), 313.

39 Welcker and Preller in the nineteenth century advanced the theory of Io as moon, but E. Plew, H. D. Müller, and J. Overbeck opposed such an interpretation. See also R. Engelmann, Roschers Lexikon d. Mythol. 2.263 ff.; Farnell, The Cults of the Greek States, 1.200; Eitrem, art. Io, $R E 9$ (1916), 1732 ff.; cf. $O C D^{2}$ (1970), 549. Further references in A. B. Cook, Zeus, 1 (1914), 454 note 8.

40 G. Kahlo, "Die jungfräuliche Mutter Io," WZULeipz, 11 (1962), H. 2, p. 427.

${ }^{41}$ Hicks, $93 \mathrm{f}$.

42 Impunity in cases of false oaths in love-intrigues is an important point beyond doubt; see R. Merkelbach, "Les papyrus d'Hésiode et la géographie mythologique de la Grèce," Chronique d'Égypte 43 (1968), 134. 
mythology; there are, in fact, many examples of the transformation of maidens into trees, animals, or birds. Pasiphaë assumed cow form to copulate with the Cretan bull and, in the Cadmus legend, the guiding cow led Cadmus to the site of Thebes in Boeotia..$^{43}$ In many of the literary and art versions, Io actually was changed into a cow-maiden who retained some human physical and mental characteristics. ${ }^{44}$ And (3)

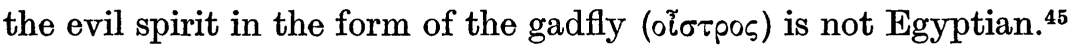

In the Io story the conception of Epaphos and the ensuing wanderings of Io are considered to be distinctive Egyptian features. Impregnation by the breath of a god is an Egyptian motif and the child born of Io was perhaps identified with Apis (Hapi).

"Eлrapos. The child to which Io gave birth in Canopus of the Nile delta

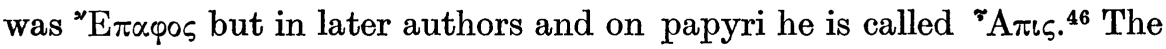
name ${ }^{2} \mathrm{E} \pi \alpha \varphi \circ \varsigma$ was held to be a purely Greek word by very few scholars, ${ }^{47}$ but the consensus now is that the name "E $\pi \alpha \varphi \circ s$ is the Hellenization of the Egyptian bull-god in Memphis, i.e. "A ${ }^{\text {N } \iota s ~(H a p i) ~ t h r o u g h ~ f o l k-~}$

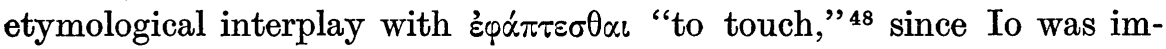
pregnated by Zeus by a touch.

The Greeks (probably Argives) living in Egypt identified Io with the

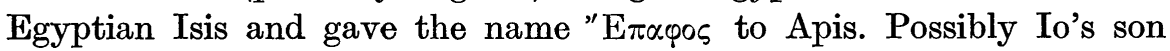
Epaphos owes his existence to a re-interpretation of the name Apis. ${ }^{50}$ This in turn has no etymology in Greek. ${ }^{51}$

43 Fontenrose, Python (1959), 314.

44 Cf. above, p. 23 with note 33.

45 Two Egyptologists tried but were unable to discover it in any Egyptian documents;

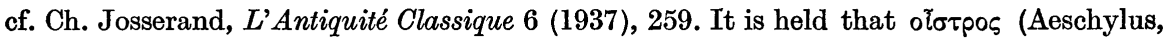
Suppl. 305f.; Apollodorus 2.3.5; etc.) also belonged to the original form of the Io myth; see C. Robert, Die griechische Heldensage, 1 (1920), 254.

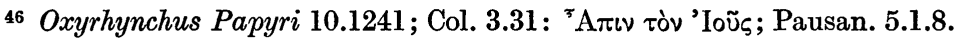

47 E.g., E. Maass, De Aeschyli Supplicibus commentatio (Greifswald, 1890-91), from غ̇ $\pi-\alpha \varphi \eta$. Cf. E. Plew, "Zu dem Mythus von To," Neue Jahrbücher für Philologie und Pädagogik 101 (1870), 671, who rejects the Hellenization of the Egyptian name Apis.

${ }^{48}$ L. Deubner, Philologus 64 (1905), 485f.; C. Robert, Die griechische Heldensage, 1 (1920) 261 ; U. v. Wilamowitz, Der Glaube der Hellenen, 1.246 note 2; J. Vürtheim, Aischylos' Schutzflehende (1928), 30-41; especially 34 (hapis was equated with ä $\psi(s)$; cf. Frisk, GEW 1.533; Chantraine, Dict. étym. 356; H. von Geisau, art. Io, Der Kleine Pauly 2 (1967), 1427.

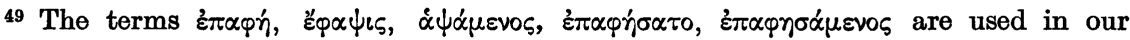
sources: Aeschylus, Prom. 849; Suppl. 18f., 45f., 1066; Apollodorus 2.1.3; Nonnus, Dionys. 3.285; Schol. Eurip. Phoen. 678; Tzetzes in Lycophron, Hal. 630.

50 See F. Wehrli, "Io, Dichtung und Kulturlegende," Festschrift f. K. Schefold (1967), 199a.

51 Vürtheim, op. cit., 59, attempted to connect $\ddot{\eta} \pi\left\llcorner\varsigma\right.$ with ${ }^{5} \mathrm{~A} \pi \iota \varsigma$ and $\dot{\alpha} \pi \tau \omega, \dot{\alpha} \varphi \dot{\eta}$, and cognates, but this is impossible; as is often the case, many philologists do not appreciate phonologic and other requirements about such etymological suggestions (cf. P. Kretschmer, Glotta 19 [1931], 176). 
The wandering of Io in search of her child, stolen upon Hera's command by the Curetes and finally found by Io in Phoenicia and specifically at Byblos (in Syria, now in Lebanon), ${ }^{52}$ seems to be a reminiscence of Isis' travels to find the body of Osiris..$^{53}$

It is a difficult task to determine the time and manner of the contact of Io's myth with Egypt, but Hicks has made the effort in that line. While the myth itself arose in the Mycenaean period (since Hera's cult at Tiryns and Argos was Mycenaean), the initial Egyptian influence appears to Hicks to have probably occurred at that time. The myth was certainly treated in epics which were lost for us, but we do have the earliest extant treatment by Aeschylus (Suppliants and Prometheus Bound); who gave to the tale Egyptian coloring and atmosphere, which he drew from Hecataeus' Пepíodos rĩ s "chart (or map) of the earth." And since we learn that Io was represented in her cow shape on the throne at Amyclae (Pausanias 3.18.13: "Hera is gazing at Io, the daughter of Inachus, who is already a cow"), the metamorphosis was known to the artists of the sixth cent. B.C. The identification or fusion of Io and Isis (the latter goddess had been known to the Greeks at Naucratis for a long time) was firmly established after the cult of Isis was introduced into Athens by Egyptian traders living in Piraeus. Literary and art representations of Io-Isis are multiplied in the Ptolemaic and Roman Imperial periods. ${ }^{54}$

The myth of Io, being composite in nature, owes much to the genius of Greek poets, a great deal to the observations of Greek travelers, and enough to the syncretistic cults of the Roman empire. ${ }^{55}$

\footnotetext{
52 Apollodorus 2.1.3.

53 Fontenrose, Python (1959), 185; Hicks, op. cit., $95 \mathrm{f}$.

54 F. Wehrli, op. cit., 199a; Hicks, op. cit., 96.

55 Hicks, op. cit., 97.
} 


\begin{abstract}
ADDENDA
Between the delivery of the typescript of this study to the Editor and the time proofs were received in March 1971, I was in the position to study further the main lines under investigation as well as details. In bibliography, some items are added here and, though the myths involved hardly affect the outcome of the discussion and of proposed interpretations, I thought that presenting bibliographies on the myth of Helle and on that of Io might be welcome in some scholarly quarters.
\end{abstract}

\title{
A. BIBLIOGRAPHY
}

\section{GENERAL (and abbreviations)}

Eugène Belin de Ballu, L'histoire des colonies grecques du littoral nord de la Mer Noire; bibliographie annotée des ouvrages et articles publiés en URSS de 1940 à 1962. 2nd ed. Leiden, Brill, 1965. [See Rostovtsev below.]

BICS = Bulletin of the Institutes of Classical Studies. London.

A. Delatte, Les portulans grecs. Paris-Liège, 1947.

[Great Britain] Hydrographic Department, Admiralty. The Black Sea Pilot, comprising the Dardanelles, Sea of Marmara, Bosporus, Black Sea, and Sea of Azov. 8th ed., 1930. London, 1930. 420 p. Index, 385-412 [The recent ed. was late; see p. 127.]

Idem, Supplement, No. 8 - 1940, relating to the Black Sea Pilot ... corrected to 20th May, 1940. London, 1940. 83 p. [Additions, alterations, and deletions are made on the preceding item. On p. $82 \mathrm{f}$. 55 new or altered names are listed alphabetically.]

Th. Homolle, "Inscriptions et monuments figurés de la Thrace," Mélanges d'archéologie et d'épigraphie, 1892, pp. 307-581. [This material was used also by W. Tomaschek.]

JHS = Journal of Hellenic Studies.

Albin Lesky, "Hethitische Texte und griechischer Mythos," Anzeiger der Österreich. Akad.d. Wiss., philos.-hist. Kl., Jahrg. 1950, Nr. 9, pp. 137-159 [on the origin of the myth of the gods in Hesiod's Theogony from the Near Eastern mythologies].

G. G. Mateescu, "I Traci nelle epigrafi di Roma," Ephemeris Dacoromania 1 (1923), 65-70, 92 [lists many other works on Thracian].

Robert Mayer, "Über die Meeresstraße von Konstantinopel als Durchgangslinie," Mitteilungen der Geographischen Gesellschaft Wien, 1942, pp. 117-142 [I have not seen this].

Eugen Oberhummer, art. Bus, $R E 5$ (1897), 1072; cf. also id., $R E 5$ (1897), $754 \mathrm{f}$.

Idem, "Die Meerengen als Erdteilgrenze," Bulletin de l'Institut Archéologique Bulgare 16 = Sbornik Gavril Katsarov (Sofia, 1950), pp. 301-303.

S. Piggott, "Iron, Cimmerians, and Aeschylus," Antiquity (Cambridge) 38 (1964), $300-303$.

F. Preisigke, Namenbuch. Heidelberg, 1922. Cf. the supplement by D. Foraboschi (above, p. 113, note 22).

Michael Rostovtsev [1870-1952], Skythien und der Bosporus. Band I: Kritische Übersicht der schriftlichen und archäologischen Quellen. Berlin, 1931. Large format, 651 pp. [On pp. 613-628 abundant bibliography up to 1930 of works relating to the history, archaeology, and culture of the Cimmerian Bosporus. But no material on, or explanations of, place-names are included. See above Ballu.]

TAPA = Transactions of the American Philological Association.

WZULeipz $=$ Wissenschaftliche Zeitschrift der Universität Leipzig, Gesellschafts- und Sprachwissenschaftliche Reihe. 


\section{ON THE MYTH OF HELLE AND PHRIXOS}

Arthur B. Cook, Zeus: A Study in Ancient Religion. 3 vols. Cambridge, 1914/25/40. Vol. 1 (1914), 414-419.

O. Gruppe, Griechische Mythologie und Religionsgeschichte (München, 1906), 565, 1146.

L. Radermacher, Mythos und Sage bei den Griechen ${ }^{3}$. Vienna, 1943.

Carl Robert, Die griechische Heldensage. 1. Buch: Landschaftliche Sagen (Berlin, 1920), pp. 41-51.

\section{ON THE MYTH OF IO (AND EPAPHOS)}

Jean Bérard, "Les Hyksos et la légende d'To; recherches sur la période prémycénienne,'. Syria (Paris) 29 (1952), 1-43 [a very important new approach].

Idem, "De la légende grecque à la Bible, Phaéton et les sept vaches maigres," Revue de l'histoire des religions (Paris) 51 (1957), 221-230 [important as the preceding item].

Arthur B. Cook, Zeus, Vol. 1 (1914), 438f. [on Io]; 453-438f. [Hera and To]

R. Engelmann, "Die Jo-Sage," Jahrbuch des kais. Deutschen Archäolog. Instituts (Berlin) 18 (1903), 37-58.

Lewis R. Farnell, The Cults of the Greek States (Oxford, 1907), 1. 199f. [on Io].

Joseph Fontenrose, Python: A Study of Delphic Myth and its Origins (Berkeley, 1959). [On To pp. 185, 314, 338, 484.]

H. von Geisau, art. Io, Der Kleine Pauly 2 (1967), $1426 \mathrm{f}$.

O. Gruppe, Griechische Mythologie und Religionsgeschichte. München, 1906. [2.59, 460, $503,747,1125$.

Ruth I. Hicks, "Egyptian Elements in Greek Mythology," TAPA 93 (1962), 90-108. [Four myths are discussed, those of Io, Helen, The Danaides, and Busiris. The first among these is the "Metamorphosis and Wandering of Io," pp. 93-97. The author concludes that these myths were borrowed from Egypt but are Greek in spirit.]

Joseph C. Hoppin, "Argos, Io, and the Prometheus of Aeschylus," Harvard Studies in Classical Philology 12 (1901), 335-345. [Analysis of the artistic conception of the Io myth in Greece until the fifth cent., examination of the literary evidence, and comparison of the two. Conclusions, p. 345.]

Felix Jacoby, "I $\Omega$ KA $\Lambda$ I@YE $\Sigma \Sigma$ A," Hermes 57 (1922), 366-374. Cf. Hesychius s. 'Í́.

Ch. Josserand, "To et le Taon," L'Antiquité Classique 6 (1937), 259-263.

Gerhard Kahlo, "Die jungfräuliche Mutter Io," WZULeipz, 11 (1962), 425-429.

Reinhold Merkelbach, "Les papyrus d'Hésiode et la géographie mythologique de la Grèce," Chronique d'Égypte (Bruxelles) 43 (1968), 133-155. [A survey of the content of the fragments of the new edition of the (Hesiodic) Catalogue; the great genealogic trees, including the genealogy of To. Very important for mythological geography.]

Uberto Pestalozza, "BO $\Pi I \Sigma$ IOTNIA 'HPH," Athenaeum, NS, 17 (1939), 105-137.

Eugen Plew, "Zu dem Mythus von der Io," Neue Jahrbücher für Philologie und Pädagogik 101 (1870), 665-672. Cf. also his review of J. Overbeck's Commentatio de Ione (1872) in: Neue Jahrbücher für classische Philologie 107 (1873), 1, pp. 697-700.

Carl Robert, Die griechische Heldensage. 1. Buch: Landschaftliche Sagen (Berlin, 1920), pp. 253-266.

Wilhelm H. Roscher, Über Selene und Verwandtes. Leipzig, 1890. (Studien zur griechischen Mythologie und Kulturgeschichte vom vergleichenden Standpunkte, 4. Heft.) 202 p. [Kapitel II: Die Namen der griechischen Mondgöttin, pp. 16-18.]

Idem, Nachträge zu meiner Schrift "Über Selene und Verwandtes" (Leipzig, 1895, 56 p.) [Kap. II, p. 19f.]

Edith Schönert, "Der To-Mythos auf den Silbermünzen von Byzanz," Helikon 6 (1966), 174-182. [The author's result is negative; no cow is represented on the coins of Byzantion 
but an ox-head that symbolizes cattle-breeding in the area, as the dolphin on other coins symbolizes Bosporos, the sea.]

Albert Severyns, "Le Cycle épique et l'épisode d'Io (Eschyle, Prométhée, 771 et s.)," Le Musée Belge (Liège-Paris) 30 (1926), 119-130.

C. Sourdille, "Une théorie récente sur la formation du mythe d'Épaphos," Revue des études anciennes, 4 e série, 14 (1912), 267-276. [A refutation of the article of the American Ivan M. Linforth, "Epaphos and the Egyptian Apis," University of California Publications in Classical Philology 2 (1910), No. 5, pp. 81-92].

J. Vürtheim, Aischylos' Schutzflehende (mit ausführlicher Einleitung, Text, Kommentar, Exkursen und Sachregister). Amsterdam, 1928, 30-41 [on Epaphos], 49-53 [on Io], 54-59 [Herkunft des Mythos].

Fritz Wehrli, "To, Dichtung und Kulturlegende," Festschrift f. Karl Schefold (Bern, 1967), pp. 196-199.

Joseph Wiesner, Olympos: Götter, Mythen und Stätten von Hellas. Topographischmythologischer Führer durch das klassische Hellas (Nieder-Ramstadt bei Darmstadt: E. Techow, 1960), $56 \mathrm{f} ., 79$.

\section{B. NOTES}

P. 70 with $n .1$ (cf. also p. 71f. with n. 12): The Straits a unique specimen.

The traffic function of the Straits of Bosporos and the Dardanelles in connection with the Strait of Gibraltar (fretum Gaditanum) as a unique access from the Atlantic ocean into a widely branched-out landlocked sea with all its hinterland has no match on the entire Earth. Cf. Oberhummer, Sbornik Gavril Katsarov, 301.

\section{P. 70 with nn. 3 and 4: The straits are drowned furrows.}

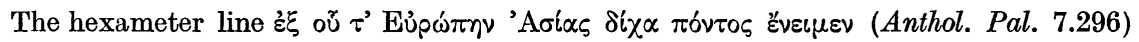
characterizes a time proverbially far in the past, at which the straits were thought to have originated through a breakthrough of the sea. Cf. Oberhummer, op. cit., 301.

\section{P. 70 with nn. 5 and 6: The currents.}

The double current in the Bosporos was ascertained for the first time by Count L. F. Marsili of Bologna (1658-1730) in his work titled "Osservazioni al Bosforo Tracio" (Rome, 1681). Cf. Oberhummer, op. cit., 303.

P. 71: The Straits as the boundary between the two continents. Cf. also Obsrhummer, op. cit. $301 f$.

\section{P. 70-72: Colonization by the Greeks in the Black Sea area.}

Recent studies are as follows:

R. M. Cook, "Ionia and Greece in the Eighth and Seventh Centuries, B.C." JHS 66 (1946), 67-98 (colonization, pp. 70-80).

E. Akurgal and L. Budde, "Vorläufiger Bericht über die Ausgrabungen in Sinope." Ankara, 1956 (Türk Tarih Kurumu Basimevi). Cf. also E. Akurgal, Anatolian Studies 5 (1955), 23.

E. Akurgal, "Recherches faites à Cyzique et à Evgili," Anatolia 1 (1956), 14-24.

A. J. Graham, "The Date of the Greek Penetration of the Black Sea," BICS 5 (1958), $25-42$.

The early presence of the Greeks in the Black Sea in the eighth century is argued successfully by A. J. Graham, and Pontus was known to them by - at the latest - 700 B.C. (p. 34, 38f.). The excavations at Daskyleion 20 miles to the south of Cyzicus showed that Cyzicus had been colonized by the Milesians before 700 B.C. to make them sufficiently 
strong and numerous to colonize Daskyleion in the interior, whose pottery is dated to ca. 700 B.C. From the presence of the Greeks in the Propontis their probable appearance in the Pontus is reasonably argued, for Cyzicus, Bosporos, and Sinope were all famous for their fish in antiquity and these coasts were explored by fishermen (Akurgal, Anatolia 1.15ff.; Graham, op. cit., 32). The myths localized in the Euxine might also be indirect evidence for the early Greek presence there (cf. Note on the myth of Io).

\section{P. 72f. with n. 15; 80f.: Hellespont (Dardanelles).}

A detailed description and measurements of the strait are found in Black Sea Pilot ${ }^{8}$ (1969), 90. Length 35 miles, breadth extremes seven-eighths of a mile and four miles; depth in mid-channel between 40.2 and 100.6 meters. The eastern side of the narrows is Kale Sultaniye, known also as Dardanelles (16,000 population in 1955). The Old Castles of Europe and Asia are Çanak-kalesi, a massive quadrangular stone fort, and its opposite castle Kilitbahir, both erected by Mehmed II in 1470.

The ethnic "E $\mathrm{\lambda} \lambda \eta \sigma \pi \delta v \tau \iota \iota_{5}$ "Hellespontine" had become also a given name in Athens in the mid-fifth cent. B.C. in remembrance of warfare around the Trojan coast (J. Kirchner, Prosopographia Attica [1901-03], 4668; cf. W. Judeich, "Politische Namengebung in Athen," EIITYMBION Heinrich Swoboda dargebracht [Reichenberg, 1927], 101; cf. also P. Kretschmer, Glotta 18 [1930], 232).

\section{P. 73: The Names of the Dardanelles.}

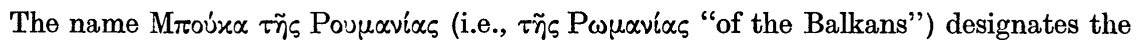
Dardanelles in a Greek portolano (sixteenth cent.); A. Delatte, Les portulans grecs (1947), p. 242 , 1. 26.

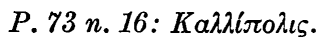

A fourteenth-cent. form Chalipoli is recorded: ein vest genant Chalipoli (dated 1396); Joh. Schiltberger, Reisen, ed. K. P. Neumann (München, 1859), p. 93.

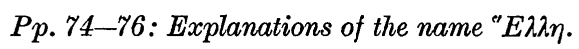

\section{P. 74: Helle Prehellenic?}

That the obscure name Helle may have been pre-Hellenic was stated also by A. Lesky (Wiener Studien 46 [1927/28], 127-129), accepted by his fellow Austrian L. Radermacher, Mythos und Sage bei den Griechen ${ }^{3}$ (1943), 182.

Lesky linked " $E \lambda \lambda \eta$ further with ' $E \lambda \lambda$ oi (and " $E \lambda \lambda \eta \eta \varepsilon \varsigma$ ), as presented above p. 77, but this was nothing novel; it is again a repetition of what A. Fick had presented in 1897 and 1901 ; see addenda to p. 75, p. 122.

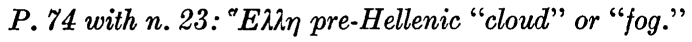

The wholesale assigning of the sense "cloud" to names is to be credited to Ed. Gerhard (Phrixos der Herold, Berlin, 1842) and was adopted and further elaborated on by Preller;

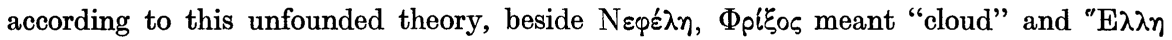
signified a "shining cloud." This outrageous invention was rejected; cf. H. D. Müller, Mythologie der griechischen Stämme, 2,1 (Göttingen, 1861), $162 \mathrm{f}$.

Concerning "fog" and "north" in the case of the assumed noun *hela and its derivatives it is important to heed the realia. I have uncovered the following facts. In the Bosporos during the five-month period from October to March, fogs with calms and light winds from the northeast are experienced but they clear off at sunrise. Fogs come on sometimes with light SW winds during the same period but clear away in the afternoon. In winter, sudden shifts of wind are frequent and dangerous, especially if they come on, as often is the case, at the same time as a thick fog. In the open Black Sea fogs frequently occur in 
April and May but on its western coast they occur from the end of September until the beginning of May. On this and more details see Black Sea Pilot ${ }^{11}$ (1969), 60-62.

The significant point here is that no fogs are mentioned for the Hellespont. The climate of the Dardanelles, one of the Mediterranean type, is generally good, the winter is on the whole mild, but spells of cold weather are brought by the northerly winds. In contrast, the weather of the Bosporos is rather variable, and there are short periods of very cold weather, sometimes accompanied by heavy snowstorms (op. cit., 60f).

My conclusion is that Mr. Deroy's theory cannot stand from the factual viewpoint of realia.

\section{P. 75: Haupt's explanation of " $E \lambda \lambda \eta$.}

Paul Haupt's attempt at the explanation of "E $E \lambda \lambda$ was abortive. One of the reasons is that it was not really a new explanation but derived in toto from what A. Fick, "Die griechischen Verbandnamen (Ethnika)," BB 26 (1901), 239, had written: "E $\lambda \lambda \alpha$ and 'E $\lambda \lambda$ -

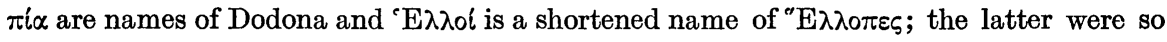
named from their habitation in the " place around Pharsalos and in the Apollo hymn for "Middle Greece" was derived from

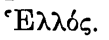

Earlier A. Fick had expounded his theory like this: for the early epic name "E $E \lambda \eta \eta$ s

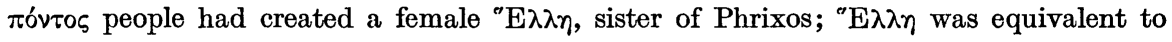

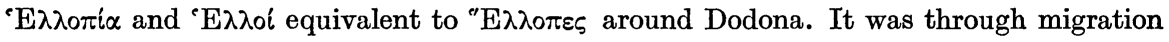

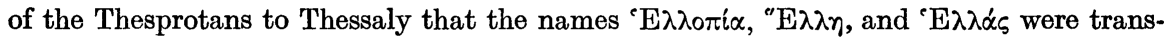
planted there and, along with the immigrants, from Thessaly to the Troas. See A. Fick, "Altgriechische Ortsnamen II," $B B 22$ (1897), 12.

Both versions of Fick's attempt did not convince any serious scholar. However, the version of 1901 connecting "E $\mathrm{\lambda} \lambda \eta$ with है $\lambda_{0 \varsigma}$ "swamp" must have attracted Haupt and Georgiev.

Linking of "E $\mathrm{E} \lambda$ oi or $\Sigma \varepsilon \lambda \lambda$ oí with Gothic saljan "sacrifice" and Latin Salii (H. Güntert, "Über die Namen Achaier und Hellenen," Wörter und Sachen 9 [1918], 130-136) was rightly rejected by P. Kretschmer ("Literaturbericht. Griechisch," Glotta 17 [1928], 250) on account of the vowel difference: sal- in salire "dance" versus hel- (ibid.).

\section{P. 76: The Hellespont and the Bosporos are maritime rivers.}

Cf. on the Strait of Messina what is said: "lo Stretto di Messina, quasi come un fiume"; Guida d'Ttalia del Touring Club Italiano. Sicilia (Milan, 1953), p. 531.

\section{P. 76 with n. 33: "E $E \lambda \eta,{ }^{\circ} E \lambda \varepsilon \dot{v} \eta, \Sigma \varepsilon \lambda \eta \dot{v \eta}$.}

According to Roscher (Über Selene und Verwandtes, 1890, p. 17) the moon goddess $\Sigma \varepsilon \lambda \dot{n} \sim \eta$ occurs in Hesiod, Theog. 371; hymn to Merc. 100. The term $\sigma \varepsilon \lambda \eta \dot{v \eta}$ "moon" was connected with Homeric $\sigma \varepsilon ́ \lambda \alpha \varsigma$ "light, brightness, flame, torchlight" already in Plato,

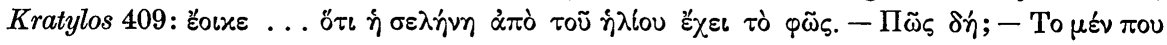

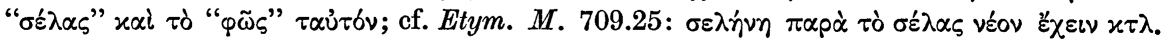
As far as "E $\mathrm{A} \varepsilon_{\mathrm{v}} \eta$ is concerned, there was a local saga in Sparta about the egg of Helen that fell from the moon (Athenaeus 57f.; cf. Eustathius 1488.21); see Roscher, op. cit., 6 with note 19. Also a moon heroine group (Helen, Phaedra) corresponding to the Aphrodite type can be traced (Roscher, 128 and 147). The moon goddess appears in cow form as do several divinities and Roscher asks the question whether the Io cow belongs here (op. cit.,

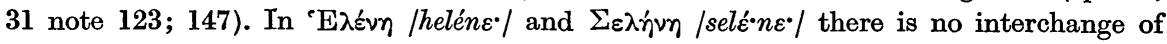
$h: s$, as erroneously suggested by G. Kahlo, WZULeipz, 1,2 (1962), p. 427a, note 60. I agree with him, however, that the interpretation of Io's as well as Isis' function as a moon goddess in ancient and in modern times was speculative. His further explanation of ' $I \omega$ 
"moon" in the dialect of Argos (Souda s.v.) as referring to the pale complexion of the moon (p. 427a) is subjective.

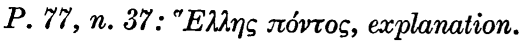

The assumption of H. D. Müller, Mythologie der Griechischen Stämme 2 (1861), 165, that

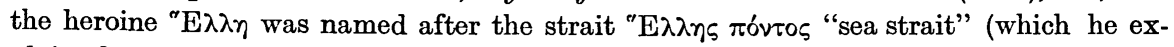

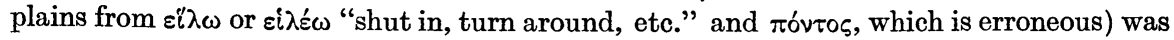
an unhappy idea (yet approved by A. Fick, $B B 22$ [1897], 12), but highly improbable, as Gruppe, Griechische Mythologie und Religionsgeschichte (1906), p. 565 and 751 note 3, already remarked.

\section{P. 78 with note 46: Helle was introduced by an Ionian.}

According to L. Radermacher, Mythos und Sage bei den Griechen ${ }^{3}$ (1943), p. 182, only the Hellespont is firmly linked with Helle, for the strait bears the name from her (the author approves of Friedländer, art. Helle, RE 8.161; and C. Robert, Die griechische Heldensage 1 [1920], 46), but he considers her mythical fall into the sea as an aetiological creation; actually, it is the poet who must have made Helle and Phrixos into sister and brother, so thinks Radermacher; according to him, an Ionian should have introduced Helle into the myth, as the Helle-reliefs are of Milesian origin (Radermacher, op. cit., 358 note 433$)$.

\section{P. 78, n. 47:}

Helle fell into the Hellespont and thus became its eponym (Robert, loc. cit.) or rather

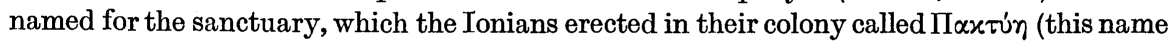

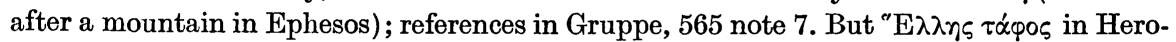
dot. 7.58; Hellanicus fr. 88; Apollodoros 2.1144. Helle's tomb in the Thracian Chersonese had no cult significance (H. von Geisau, Der Kleine Pauly 2 [1967], 1008); according to Robert (loc. cit.) a cult cannot be denied to that tomb. The legend of Helle has probably been a reproduction of the Europa legend; cf. Gruppe, 1146 (who suggests the hypothesis that the ram was originally Poseidon himself; an echo of this is the saga that Poseidon begets the golden ram by Theophane).

\section{P. 78f. with n. 50: $\Phi \varrho i \xi o s$}

The sense "cloud" for $\Phi$ pi६os has been pointed out as impossible; see above (add. to p. 74 with n. 23), p. 121. L. Radermacher's suggestion for $\Phi$ ¡ $i \xi \circ \varsigma$ as "der Schauderer" and

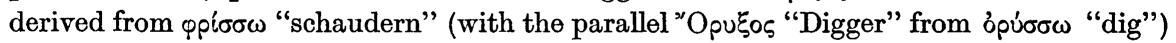
was also rejected (above, p. 79 note 50 ).

The explanation adopted above seems quite certain. A poem of Anyte of Tegea (Anthol.

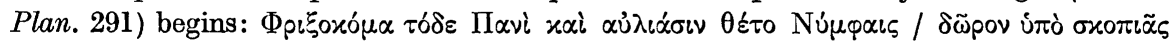

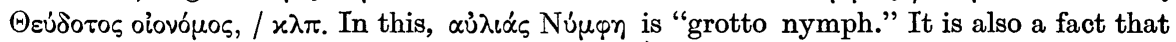

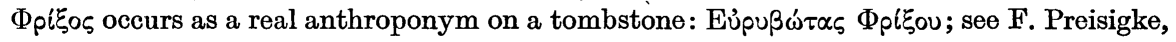
Sammelbuch 1 (1915), 5723 = idem, Namenbuch (Heidelberg, 1922), col. 468.

\section{P. 79: A possible explanation of " $E \lambda \lambda \eta$.}

In more detail the $n$-stem of $\varepsilon_{2}^{2} \lambda b_{\varsigma}$ was treated by F. Specht (Der Ursprung der indogermanischen Deklination [Göttingen, 1947], p. 115): Lith. élnis, Old Litj. elenis and Old

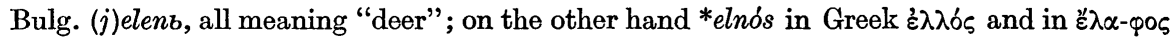
(compared with Goth. l-am-b "sheep"), and perhaps also Lat. alnus "alder" from *alen-os

\section{P. 80 with note 59: City $\Delta$ ágdavos.}

The foundations of the town Dardanos, a city older than Troy, stand on a low hill, ca one mile south of Kefez point (lat. $40^{\circ} 06^{\prime} \mathrm{N}$., long. $26^{\circ} 23^{\prime} \mathrm{E}$.). The Dardan liman is formed by the coast north of Çanak. See Black Sea Pilot ${ }^{8}$ (1930), 47 and 49; cf. ${ }^{11}$ (1969), 90. 
The name $\Delta \alpha \dot{\rho} \delta \alpha v o s$ and in its Latinized form Dardanus is a Thracian name. Dardani were the Thracian tribe and Dardania the region. Dardanus is also recorded as a name of Roman soldiers; so M. Aurel. M. f. Ulp. Dardanus recorded on an inscription of ca. A.D. 180; G. G. Mateescu, "I Traci nelle epigrafi di Roma," Ephemeris Dacoromana (Rome) 1 (1923), 92, 264; CIL 6.3650 (and numerous other occurrences).

\section{P. 81 n. 60: Was a Cape Helles the Turk. Eles burnu?}

The M $\alpha \zeta o v \sigma i \alpha$ ¿́xp $\alpha$ or M $\alpha \sigma \tau o v \sigma i \alpha$ was obviously what later was called Helles Cape, which was renamed into Ilyasbaba burnu, recently renamed Mehmetçik burnu.

At the southwestern entrance on the European shore of the Dardanelles is the headland ca. 1.5 miles in breadth, projecting SW and formed by three steep points named Tekke burnu, Ilyasbaba (= Cape Helles) (lat. $40^{\circ} 02^{\prime}$ N., long. $26^{\circ} 11^{\prime}$ E.), and Kale burnu. The SW entrance of the Dardanelles is identified by the white cliffs of Ilyasbaba (Cape Helles), on which stands a lighthouse. About one-fourth of a mile ENE of the lighthouse is the obelisk (21.3 meters high) standing on the highest point (ca. 45.7 meters high) at the south end of the Chersonese peninsula (see Black Sea Pilot ${ }^{11}$ [1969], 86).

The renaming of Cape Helles into Ilyasbaba Burun was recorded in the Black Sea Pilot, Supplement 8 (1940), p. 82 . The previous name Elés burnu recorded in 1899 (Bürchner, art. Chersonesos 1, RE 6 [1899], col. 2244) seems to have been considered by the Turks as not a good Turkish name to be renamed just in the 1930's. But Bürchner (ibid.) rejected the

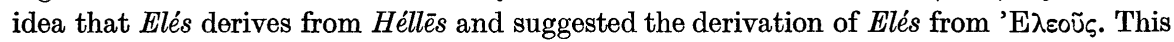
suggestion is worth noting because it is based on no evidence. Actually, an ancient city

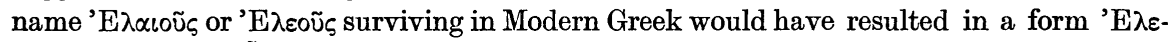

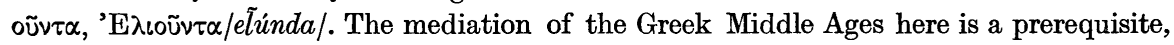
for the Turks first heard the name from the Greeks.

The traditional assumption that Turkish Eles burun came from "E $\lambda \lambda \eta \varsigma^{2} \alpha$ 'x $\alpha$ rather conforms to what was expected at the entrance of the Hellespont. To demolish this assumption would take a meticulous topographical investigation.

\section{P. $82 f$.: Bosporos.}

The Bosporos seaway begins at Old Seraglio point Saray burnu, i.e. the eastern extremity of Constantinople, and the Leander Tower (lat. $41^{\circ} 01^{\prime}$ N., long. $29^{\circ} 00^{\prime} \mathrm{E}$.), at its entrance from the Sea of Marmara and terminates at the entrance of the Black Sea at the two capes, Rumeli Hisar and Anadolu Hisar. Length of the seaway 16 miles, least width four cables. Depths from 27.4 to 120.7 meters. See Black Sea Pilot ${ }^{11}$ (1969), p. 155.

On the currents of the Hellespont and the Bosporus see the detailed exposition in Black Sea Pilot ${ }^{11}$ (1969), 39-48. The current in the Bosporos attains its maximum strength of five knots in the narrowest part of the strait between Rumeli point and Anadolu Hisar, where it is known as the Devil's current; see ibid., $41 \mathrm{f}$., 46.

\section{The Names for the Black Sea.}

The ancient characterization of the Pontus water as "black" is Iranian axšaina, hence

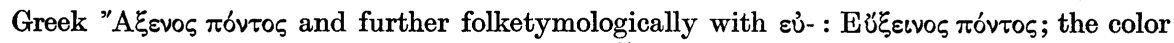
is reflected in Greek M $\alpha u ́ p \eta \Theta \alpha \dot{\lambda} \alpha \sigma \sigma \alpha$, Russ. C̆ernoye More, and Turk. Kara Deniz. It is, therefore, erroneous to state, as in Black Sea Pilot ${ }^{8}$ (1930), 122, that the Greeks called

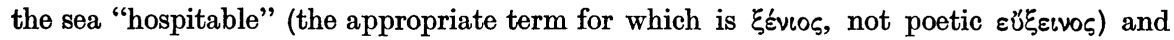
the Turks, expressing their fears in traversing such an open expanse of waters, stormy and perilous, named it "black." Nor is it any better to present without a comment the passage of Strabo (7.3.6), where he speaks of the Pontus as not navigable and being called "A $\xi_{\varepsilon i v o 5}$, owing to its wintry storms and the savagery of the people who lived around it, as a modern 
scholar, A. J. Graham (BICS 5 [1958], 25) has done. The Iranian origin of the name, as convincingly demonstrated by Max Vasmer half a century ago (1921), should be common knowledge by now.

\section{Pp. 80-82: The Dardanelles.}

The city $\Delta \alpha \dot{p} \delta \alpha v o 5$, where porto Dardano, is called Dardanelo (Dardanello) on the sea maps; W. Tomaschek, "Zur histor. Topographie von Kleinasien im Mittelalter," $S B d$. Akad. Wien, philos.-hist. Kl., 124, Abh. VIII (1891), p. 17.

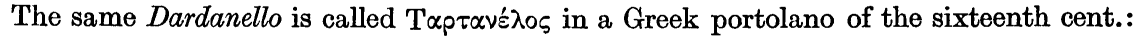

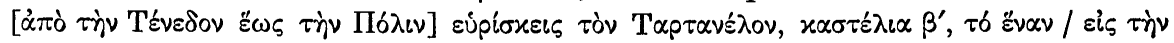

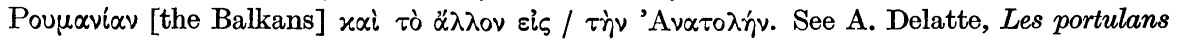
grecs (1947), p. 335, 1. 8. This testimony with the rest belies the proposed etymon of $\Delta \alpha \rho \delta \alpha \nu \varepsilon^{\prime} \lambda \iota \iota \alpha$ from $\Delta \alpha \dot{\rho} \delta \alpha \nu \circ \varsigma$ and " $\mathrm{E} \lambda \lambda \eta$.

Dardanel $(l) o$ is obviously a diminutive of Dardano; in addition to the examples given on p. 81 note 62 (Salandrella, Galatrella), add the Turkish names Aydın and Aydıncık, both occurring in the area of Ankara.

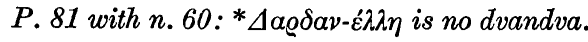

The name * $\Delta \alpha \rho \delta \alpha v \varepsilon \varepsilon_{\lambda} \eta \eta$ can hardly be understood as dvandva, if one considers closely each of such dvandva geographic names. E. Honigmann, "Les dvandvas dans la toponymie byzantine," Mélanges $E$. Boisacq (Bruxelles, 1937), 1.499-512, has assembled some 15

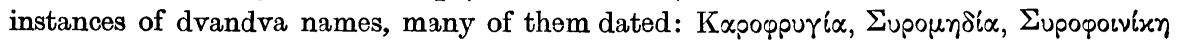

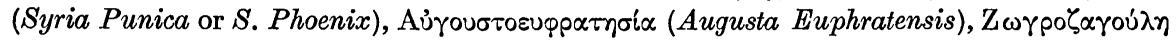

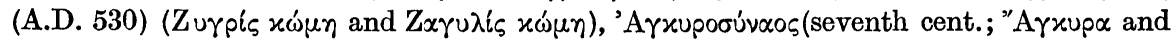

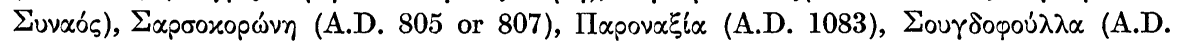

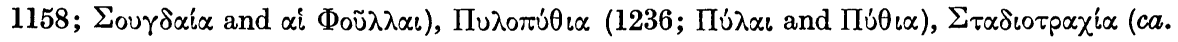

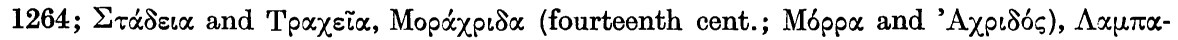
$\delta \circ \pi \alpha \rho \theta \varepsilon v^{i} \tau \alpha$ (1390; $\Lambda \alpha \mu \pi \alpha^{\prime} \delta \alpha$ and $\dot{\eta} \Pi \alpha \rho \theta \varepsilon v i \tau \alpha$, names of two ports in the Crimaea), Mo $\theta \omega$ -

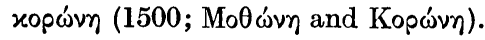

All these dvandvas semantically are equivalent to the area that includes both units.

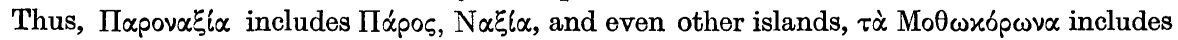

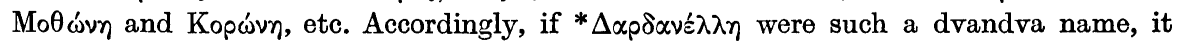
would mean "E $\mathrm{\lambda} \lambda \eta \eta$ and $\Delta \alpha \dot{\alpha} \delta \alpha{ }^{\prime} 05$, i.e. designate part of the European coast and part of the Asiatic coast but would hardly designate the maritime river between them.

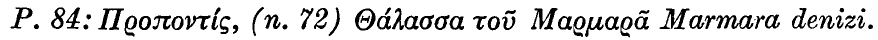

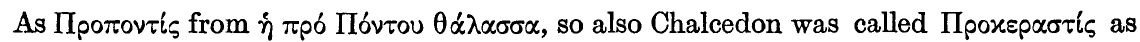

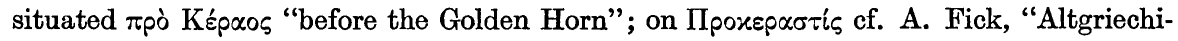

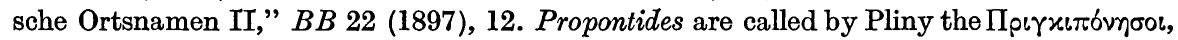
now Kizil adalar, i.e. nine islands lying parallel with the coast six miles SE of Constantinople; see Black Sea Pilot ${ }^{11}$ (1969), 101.

The Sea of Marmara, ca. 150 miles long from E. to W. and 40 miles in breadth in its widest part from N. to S., derives its name from the island of Marmara (ancient Mpoxóvvnoos), from which also the name Marmara Bogazı has its name (this is the southern chennel between the Marmara island and the Pasha Liman group). This naming occurred of course

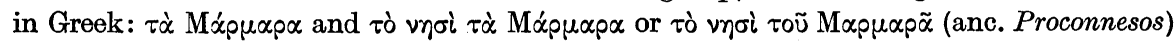
with six hamlets on the coast has given its name to the Sea and divides it into two channels of unequal breadth (op. cit., 61, 79f.); its celebrated quarries have been worked for centuries and are still on a very small scale. The debris from them has formed on the shores of Memerc lımanı a steep white slope, which is very conspicuous from the north (cf. Black Sea Pilot ${ }^{11}$ [1969], 117). 


\section{P. 84f.: Cimmerian Bosporos.}

For the period of 22 years there were listed approximately 300 Russian bibliographical items on the Cimmerian Bosporos (out of ca. 700 works referring to the ancient Greek colonies of the northern littoral in the Black Sea); see Eugène Belin de Ballu, L'histoire des colonies grecques du littoral nord de la Mer Noire (Leiden, 1962). This fact demonstrates in a way the cultural importance of the area.

\section{Pp.92-94: Bóбло@os "Hellespont."}

On account of the existence of three straits named Bóoropor in the NE Mediterranean, it seems to me that it was natural that the more distinctive term 'E $E \lambda$ in $\sigma \pi 0 v \tau \circ \zeta$ won the upper hand and became current among the Greeks and thus replaced the (Hellespontine name) Bóoropos.

\section{P. 96 n. 148: Bóблo@os "large ford."}

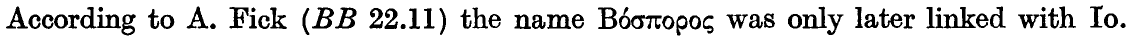

\section{P. 102 with n. 178: $\dot{\eta}$ Boṽs the Asiatic headland.}

The promontory, called Boũs f., was located NE of Boortopios $\alpha x p \alpha$ and east of the entrance to the Golden Horn (see map in Oberhummer, art. Bosporos 1, RE 5 [1897], coll. $749 \mathrm{f}$.). The name Boũ $\tilde{S}_{\text {or }}$ (according to Hesychius s.v.) $\Delta \alpha \mu \alpha \lambda_{l \zeta}$ is referred to the islet (before the west tip of Skutari), which islet carries a tower, erected by Mehmed II and called Leander Tower by the Franks and Kizkulesi "girl tower" by the Turks; both the Leander saga and the Turkish tale seem to join an obscure tradition of the ancient saga. Cf. Oberhummer, $R E 5$ (1897), 755.

Our most reliable topographical guide for the area is the Black Sea Pilot ${ }^{11}$ (1969). We are informed as follows: the shore in the vicinity of Üsküdar (on the site of ancient Chrysopolis) is bordered by a sand flat extending from 279.8 meters to 555.6 meters from it. A light (lat. $41^{\circ} 01^{\prime} \mathrm{N}$., long. $29^{\circ} 00^{\prime} \mathrm{E}$.) is exhibited at an elevation of 9.4 meters from a white framework structure (11 m. in height) on the tower (Kizkulesi), situated at the extremity of a rocky ledge extending $\mathbf{1 8 5 . 2}$ meters from the western point of Skutari. A rock with a depth of $1.8 \mathrm{~m}$. lies half a cable $(94.6 \mathrm{~m}$.) NNE of Kiz kulesi; a $5 \mathrm{~m}$. patch lies close to the north of the rock; see Black Sea Pilot ${ }^{11}$ (1969), 148.

Gruppe (Griechische Mythologie, 2.747) thinks that the recorded topographic names $\Delta \alpha \dot{\alpha} \alpha \lambda \iota \varsigma$ and Boũ $\zeta$ in the Bosporos were really given after Io in cow shape, as sacred beasts of Artemis or of the god mother identified with her gave the following names from the

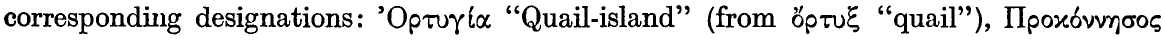

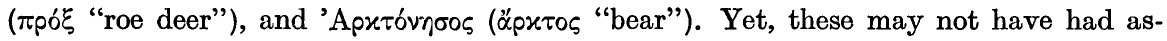
sociations with myths. Here also the fact should be recorded that the name Boũs on a papyrus of the third century A.D. stands for an anthroponym; F. Preisigke, Namenbuch (1922), col. 78 [names in Egypt]; D. Foraboschi, Onomasticon (1967-), 81 b.

\section{P. 102: Bõ̃s as Io on coins?}

A recent study has investigated the silver coins of the fifth and fourth centuries B.C. of Byzantion to ascertain whether or not the Io myth is represented on them. It was found that no cow (with udders) represents Io but an ox-head on them symbolizes cattle-breeding as the dolphin (on the same coins or on other coins) symbolizes Bosporos or the sea as the source of the wealth of the Byzantines; also agricultural land of Byzantion in Thrace and Asia Minor is represented by Demeter's head on the obverse and the cornucopia on the reverse. The Byzantines have, however, portrayed on their coins the head of Keroessa, Io's daughter, and on the reverse the ox. See Edith Schönert, "Der Io-Mythos auf den Silbermünzen von Byzanz," Helikon 6 (1966), 174-182. 


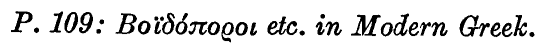

In Modern Greek the term rópos underlies simplicia and compounded place-names. From an area I have covered rather thoroughly I parade examples that speak for themselves, from the nomos of Messenia:

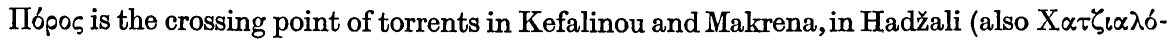

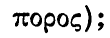

$\mathrm{B} \lambda \alpha \chi \hat{b} \pi$ opos crossing point, used by seminomadic shepherds in the area of Tzeferemini and

Hasambasa (cf. $B \lambda \alpha \chi \alpha \dot{\alpha} \mu \pi \varepsilon \lambda \alpha$ in the area of Karteroli), on the river Pirnakas;

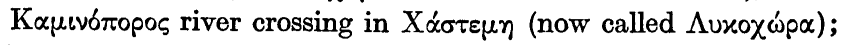

$\Pi \lambda \alpha \tau \dot{\pi} \pi 0$ os in Kaloyerorachi;

Koxкеvótropos (twice);

Пвтро́тороక;

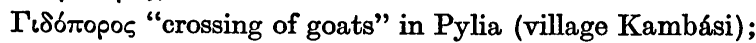

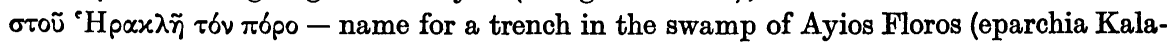
mata); the name is a man's, not the hero's.

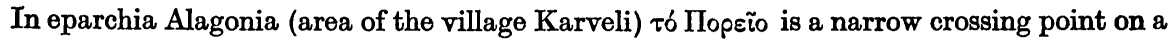
torrent.

\section{LAST ADDENDA}

In bibliography it is important to mention the latest edition of a book listed (above, p. 118): The Black Sea Pilot, 11th ed., 1969 (publ. by the Hydrographer of the [British] Navy).

Straits officially are considered and called the entire seaway of the Dardanelles, Marmara Denizi, and the Bosporus (so Black Sea Pilot ${ }^{11}$, p. 10).

Narrows, on the other hand, is the part of the Dardanelles between Çanakkale kalesi and Nara burnu (ca. 3 miles N.) on the east and Kilitbahir and Bigali kalesi (ca. 4 miles N.) on the west (ibid., p. 90).

P. 103: Boò $\varkappa \varepsilon \varphi \alpha \lambda \alpha$ l. Like this toponym is Kuvò $\varkappa \varepsilon \varphi \alpha \lambda \alpha$ l "dog's heads" from a similarity of the feature. On how the aition could arise see M. P. Nilsson, Geschichte der griechischen Religion ${ }^{2}$ (München, 1955), 30.

Pp. 78, 123: The aition for Helle's myth. - The aitiological myths or tales, called aitia, are well-known: a tale can be made into aition by adding an aitiological narrative or, conversely, a tale may originate from an etymological narrative by dropping the aitiological relationship; illustrations of both phenomena are presented by Nilsson. In addition, cult aitia frequently narrate the motive of the installation of a cult (thus, several tragedies of Euripides have an aitiological conclusion, the setting-in of a cult). See Nilsson, op. cit., 1. 26-35. 


\section{INDEX}

Note the abbreviations: $\mathrm{n}_{.}=$note, $\mathrm{nn} .=$ notes, add. $=$ addenda, app. $=$ appendix

Abbreviations 65f., 118

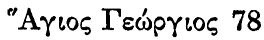

aition in myths 78,127

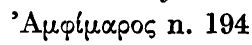

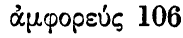

'Av'́d $\pi$ ous 82 with n. 65

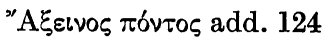

Apis, 'A ${ }^{\top} \iota \varsigma$ app. 7, nn. 46, 47, 51

'A $\pi 0 \lambda \lambda \omega \nu \eta \sigma i$ ins n. 194

Arnavutköy (Turk.) n. 65

Aydin, Aydincik (Turk.) add. 125

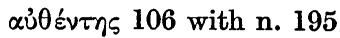

axšana (Iran.) add. 124

\section{ßśopov 106}

Bessapara n. 99

bibliography 65-69; add. 118-120

Black Sea 118; 124; - - area \& Greek colonization add. 120

ßo- in compounds 199

Bó́rplos 103

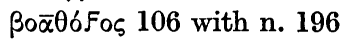

ßо $\bar{\alpha} \theta 6 \circ 5$ n. 196

ßontóos 106

Bontós 106 with n. 196

Boğazı (Turk.) 82

Boğazıčı (Turk.) 82 with n. 64

Boï $\delta 6 \pi$ opo toponym in Messenia 109 with n. 204; (parallels) add. 127

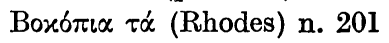

ßoo- compounds 99

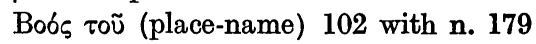

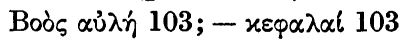

Boó́oupa 104

Boòs $\pi$ ópos 91 with n. 125; $92 ; 104$

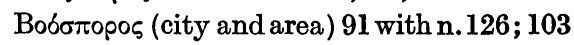

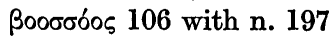

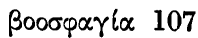

(*ßo5) 100, nn. 170, 171

Bosforo (Ital.) 86

Bòsforo (Span.) 86

Bosforus 86

Bospara, B $6 \sigma \pi \alpha \rho \alpha$ (Thracian) 87 with $\mathrm{n}$. $100 ; 89 ; 90$; n. 190

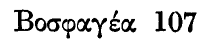

Bosphore (French) 86

bosphore (French) n. 140
Bosphoros (Lat.) 85 with n. 88; nn. 77, 79, 89; (= Hellespont) 86 with n. 93

Bóopopos (not surviving) 86 with n. 85

Bosphorus (Lat.) 84, 86

Bospór (Bosfór) (Russ.) n. 67

Bootoplavós 85 with n. 82

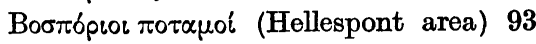

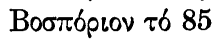

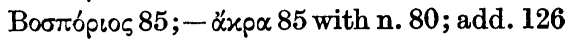

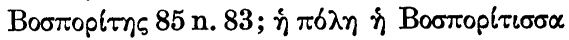
n. 84

Bosporos 69, 70; add. 120f.; realia against the Thracian explanation 88-90

Bóблopos 87f.; 89; 105; 106; 107 n. 121 (etymon in Roman authors), $94 \mathrm{ff}$. nn. $68,74,85,86$ (city), 96, 101, 127, 128, 133, 136, 137, 159; "large ford" add. 126;

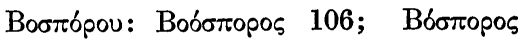
(port) 84; Bóoropos (Hellespont) 92 with n. 93 ; pp. 94-96; add. 126

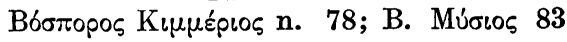

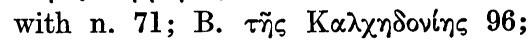
B. $\delta x \alpha \tau \dot{\alpha} \tau \dot{\eta} \nu \Pi_{p o \pi o v \tau i \delta \alpha}$ n. 131; B.

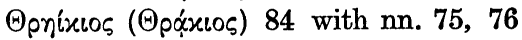

ßбблороక (noun) 94-96, 108; nn. 140, 148; "strait, channel" 108

bosporus (etc.) "fretum" (Lat.) n. 140

Bosporus (Lat.) 83, 84, nn. 77, 140; B. Cimmerius 85; B. Thracius 84, nn. 77, 91, 94; Bosporus of Italy (Strait of Messina) n. 147a

B 60 pe $\pi \tau \circ 5104$ with nn. 184, 185

ßou- compounds 99 with n. 163

Boú $\alpha 102$

Boú $\beta \alpha \lambda \circ 5$ n. 176

Boúdopos 103

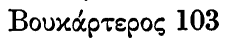

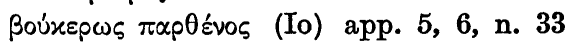

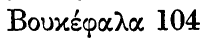

Boúxpavos f. 103

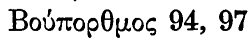

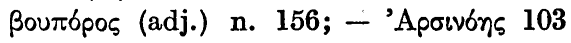
ßoúputos 96

Boũ $\dot{\eta}$ (headland) 102; add. 126; anthroponym add. 126

Bovoropirns (inhab. of city) 86 with n. 97 


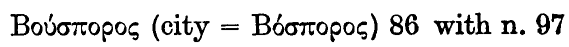
Bovoróos 106

Boupáros 103

Bova (in Italy) 102

Bove (Ital.) in descriptive place-names 102

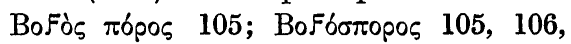
107; BoFbotropos 107

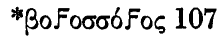

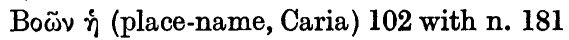

Brachium Sancti Georgii 78; 83

Bpl $\alpha$ f. 90 with n. 118

Bpírapov 90 with n. 118

Bpóxor n. 185

Bucca Romaniae 73

Bufalo 102

Callipoli (mediev. Lat.) n. 16

Çanakkale Boğazı (Turk.) 72

Çanak-kalesi (Turk). 81; add. 124

canal (Ven.) n. 6

Cape Helles n. 60; add. 124; C. Greco, C. Tekke add. 124

Cavallo (Ital.) 101

Cavallón (Span.) 101

Črnoye More (Russ.) add. 124

Cervo (Ital.) 101

Chalipoli add. 121

Cimmerian Bosporos 84f.; add. 126; Straits 69

Cimmerius Bosporus n. 121; - Bosphorus 86 with n. 92

colonization of Greeks in Black Sea add. $120 \mathrm{f}$.

compound names: genitive $-103 f$

cow form of Io app. 114-116

currents 70 ; add. 120

$\Delta \alpha \dot{\alpha} \alpha \lambda$ is f. add. 126

Dardanelles, the, 71 ; 73; 80; n. 58; add. 123

* $\Delta \alpha p \delta \alpha v \varepsilon ́ \lambda \lambda \eta$ (dvandva) 81; add. 125

Dardanelli (Russ.) 80

$\Delta \alpha \rho \delta \alpha \nu \varepsilon^{\prime} \lambda \lambda_{\iota} \alpha \tau \dot{\alpha}, 80$; (city) 81; etymon add. 125

Dardanello (Ital.) n. 62; add. 125; Dardanelli 80

$\Delta \alpha \dot{\rho} \delta \alpha \nu \circ \varsigma 80$ with n. $59 ; \dot{\eta}-$ (city) 82 and n. 63 ; add. 123f., 125; $\Delta \alpha \dot{\rho} \delta \alpha v o s, \Delta \alpha \rho-$

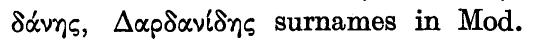
Gr. n. 59

Dardanus add. 124

deities of light $76 \mathrm{f}$.

descriptive names for "Bosporos" n. 69
Devil's current add. 124

digamma $(F)$ in Mycen. and Doric 105

dvandva geographic names add. 125

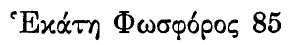

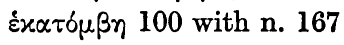

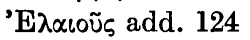

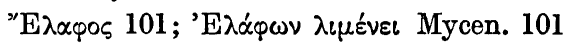

'Exévn 76; add. 122

Eles burun (Turk.) n. 60; add. 124

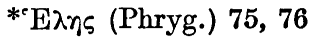

${ }^{\circ} \mathrm{E} \lambda \lambda \bar{\alpha} 77$

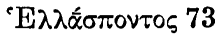

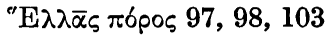

$\varepsilon \lambda \lambda \eta$ (noun) $76 \mathrm{f}$.

*ย่ $\lambda \lambda \dot{n}$ (noun) 79

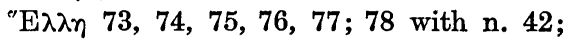

79 ; 80 ; add. 121f., 123, 125

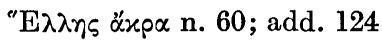

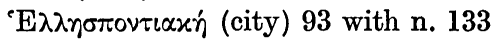

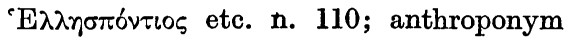
add. 121

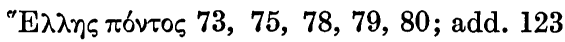

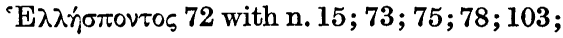
(semantic content) n. 15; (river) n. 110; (land) n. 110; add. 123

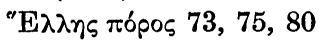

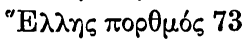

$-\varepsilon \lambda \lambda \iota$ suff. 81 with nn. 60, 62

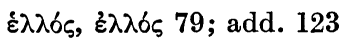

'E $\mathrm{\lambda} \lambda$ ol 77; add. 121, 122

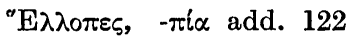

हैंगs 75; add. 122

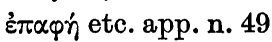

Epaphos app. 112, 116; add. 119f; "E $\pi \propto \varphi \circ \varsigma$ app. 116

'E $\pi \tau \dot{\alpha} \pi$ \%ороร 97 with n. 152

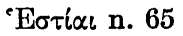

$\eta \tilde{\lambda} \cos 77$

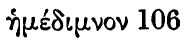

etymologizing onomastic data 72

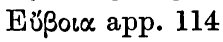

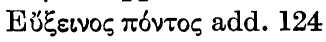

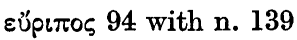

Euriposo; 94

fiume del Lupo 101

Fjord n. 189

floating cattle in high water n. 203

fog in the Straits add. 121, 122

Foggy Island, Foggy Peak 74

folketymological forms of Bosporos 85 
ford 90,104

*furdu (Germanic) 104

Furt 104

Galatrèlla n. 62

Galliparo 97 ; cf. $\mathrm{K} \alpha \lambda \lambda$ íropos

Gallipoli 73, n. 16

Gelibolu (Turk.) n. 16

Golfo di Gallipoli 73

gworā 88

$\mathrm{g}^{\mathrm{W}}$ Owos poros 89

gwos 101, n. 171

$\left(\mathrm{g}^{\mathrm{W}} \mathrm{Os}\right) 101$

haplology 106

Hathor (Egypt. goddess) app. 114, 115

(*hela) 74; add. 121

(*hella, *Hellane) 74

Helle (myth) 69; add. 119 [bibliography], $121 \mathrm{f}$.

Hellespont 69, 70; add. 121

Hellespontos, (Lat.) -us 72

hydrography of Bosporos 70 n. 5; 71 n. 9

Hyksos app. 161

hyphaeresis (loss of one of vowels) 98 with nn. 160, 161

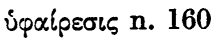

'Ispóv nn. 65, 73

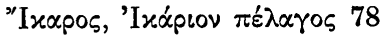

Ilyasbaba burnu (Turk.) add. 124f.

Io (myth) $69,87,91$ with n. 122; 92 with n. 127; 109 with n. 205; app. 110-117; equated with Isis app. 115, 117, 122; bibliography 119f.; 'Í́ app. n. 22

"I $\pi \pi \circ \mathrm{s} 101$

Istanbul Boğazı 82 with n. 64

Kale Sultanije n. 62; add. 121

$\mathrm{K} \alpha \lambda \lambda i \pi \circ \lambda_{\text {ls }} 73 \mathrm{nn} .16,65$

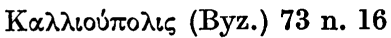

$\mathrm{K} \alpha \lambda \lambda i$ iтороร 97 with n. 153

kanal (subsurface current) (Turk.) 70 with n. 6

Kara Deniz (Turk.) add. 124

Karadeniz Boğazı (Turk.) 82 with note 64

Kerch, Strait of, 71, 85, n. 78

Kilid Bahr (Turk.) add. 121

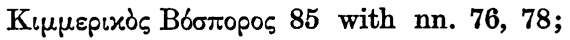
i $\sigma \theta \mu b s$ K. n. 78

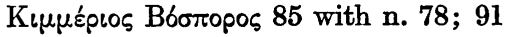

xเóxpavov 106

Kizkulesi (Turk.) add. 126

Kuvòs $x \varepsilon \varphi \alpha \lambda \alpha i 127$

Kuru-çesmé n. 65

lāw-, lāwo-, -lāwos compounds 105

$\Lambda \bar{\alpha} F_{-}, \Lambda \bar{\alpha} F_{0-},-\lambda \bar{\alpha} F_{0 \varsigma}$ compounds 105

Leander Tower add. 126

Loup 101

$\Lambda$ úxos 101

maritime rivers 70

Ḿ́p $\mu \alpha \rho \alpha \tau \dot{\alpha}$, add. 125

Marmara Boğazı (Turk.) n. 64

Marmara Denizi (Turk.) n. 72; add. 125

M $\propto p \mu \alpha \rho \tilde{\varsigma} \varsigma \mathrm{m}$. (village) n. 72

M $\alpha \sigma \tau o v \sigma i \alpha, M \alpha \zeta o v \sigma i \alpha \alpha^{\prime} x p \alpha$, n. 60; add. 124

moon goddess add. 122

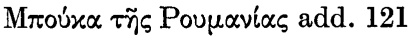

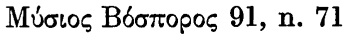

mythological conceptions and geography 72

myths localized in Euxine add. 110

Narrows (U.S.A.) n. 66; add. 127

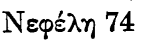

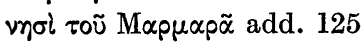

o from oo 98, 99, 107, n. 185

Ochse (Germ.) in place-names 102 with n. 177

Ochsenfurt 102

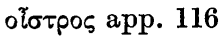

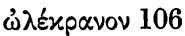

'Opturi $\alpha$ add. 126

ox-ford 109

Oxford 104; six times in U.S. 104 with n. 188

ox-head on Byzantion coins add. 126

Паxт̛́n 78

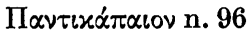

-para (etc.) Thracian compounds 87 with nn. 99, 100, 111

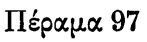

periphrastic names $103 \mathrm{f}$

Phoenicians app. 111 with n. 7

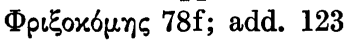

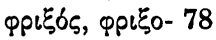

$\Phi$ pl६os 78f.; add. 119, 121, 123; bibliography on - add. 119

$\varphi \tilde{\omega} \varsigma 89$

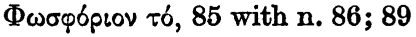




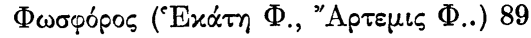
with n. $88 ; 89$

place-names from animal terms $101 \mathrm{f}$.

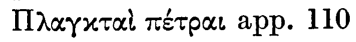

$\Pi \lambda \varepsilon เ \sigma \theta \varepsilon \dot{v} \eta \bar{s} 106$

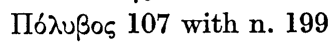

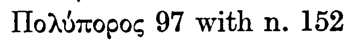

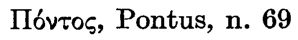

por-a (IE) 90

-pora (OChSl) n. 117

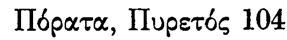

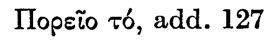

-poris (Thracian) n. 99

Pòro (torrent) in S. Italy 97 with n. 150

*poros (IE) 88

Tópos 88, 97, 103 with nn. 99, 100, 101, 149, 151, 152; add. 127; (Phryg.) 75;

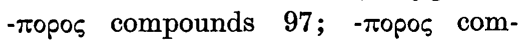
pounds in Mod. Greek place-names add. 127

П'́pos 97 with nn. 151, 152; add. 127

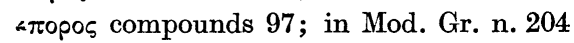

$\pi о p \theta \mu o ́ s$ 73, 97; in geogr. names n. 155

Порөноós 97

Porto Dardano add. 125

Portus Prosphorius 86 with n. 95

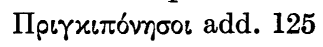

Прохєр $\sigma \tau i \zeta \varsigma$ add. 125

Прoxóvvทбos add. 125

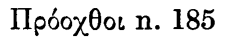

Протоvтіs 69, 70, 84; add. 125; Propontides (Lat.) add. 125

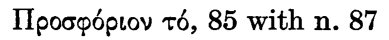

Пробфóplos $\lambda \iota \mu$ 'v 85 with n. 87

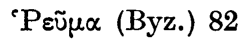

rivers fordable n. 203

river valleys 70

Salandra, Salandrella n. 62

Salii (Lat.) add. 122

salinity of the water in Hellespont and Bosporos 71 with $\mathrm{n} .7$

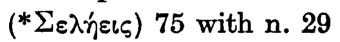

$\Sigma \varepsilon \lambda \dot{\eta} \sim \eta, \sigma \varepsilon \lambda \eta ุ \sim \eta ~ 76,77$; add. 122

$\Sigma \varepsilon \lambda \lambda \hat{n} \varepsilon i \varsigma$ n. 29

$\Sigma \varepsilon \lambda \lambda$ ol add. 122 semantic content depleted in compounds n. 202

sēmodius 106

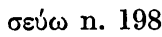

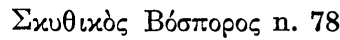

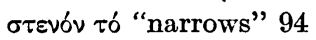

$\Sigma_{\tau \varepsilon v o ́ v} \tau o ́, 82$ f. with n. $66 ; 94 ; 109 ; \tau \dot{\alpha} \Sigma \tau \varepsilon v \alpha ́$

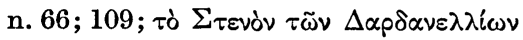

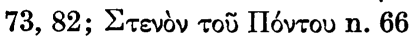

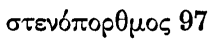

Stenum n. 66

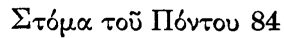

Straits of the Dardanelles (Nagara \& Çanak) 71; Strait(s) of Gallipoli 73 with n. 16; 82; Strait of Gibraltar n.7 ; add.120,127; Strait of Kerch 78; history of the Straits 72; Straits as boundary between Europe and Asia 71; add. 120

Stretto della Romania 73; Stretto di Messina add. 122

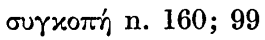

$\Sigma \cup \mu \pi \lambda \eta \gamma \alpha \dot{\delta} \delta \varepsilon$ app. 110

swimming cattle in floods n. 203

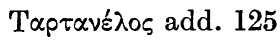

Taũpos 101

terms designating animals as place-names $101 \mathrm{f}$.

$\tau \varepsilon \tau \rho \alpha \dot{\chi} \chi \mu \circ \nu 106$

$\theta \dot{\alpha} \lambda \alpha \sigma \sigma \alpha$ (etymon) 80 note 56

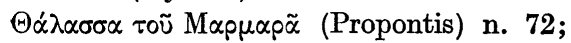
add. 125

Thracian Bosporus n. 76

Thracian language 87 with n. 103

Thracius Bosphorus 86 with n. 91

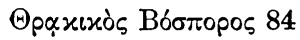

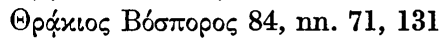

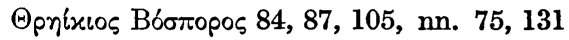

Toro 102

Vache enragée 102

Vospór (Russ.) n. 67

Vósporos (Mod. Gr.) 82f. with n. 67

Vúa (S. Calabria) 102 with n. 180

waterway geogr. features (between the Aegean \& the Black Sea) 69

Yoros (Turk.) = ${ }^{\top} I$ I póv n. 73

\section{University of North Dakota}

